

\section{NOTICE}

This report is being disseminated by the U.S. Department of Energy (DOE). As such, this document was prepared in compliance with Section 515 of the Treasury and General Government Appropriations Act for fiscal year 2001 (public law 106-554) and information quality guidelines issued by DOE. Though this report does not constitute "influential" information, as that term is defined in DOE's information quality guidelines or the Office of Management and Budget's Information Quality Bulletin for Peer Review, the study was reviewed both internally and externally prior to publication. For purposes of external review, the study benefited from the advice and comments of nine energy industry stakeholders, U.S. Government employees, and national laboratory staff.

This report was prepared as an account of work sponsored by an agency of the United States government. Neither the United States government nor any agency thereof, nor any of their employees, makes any warranty, express or implied, or assumes any legal liability or responsibility for the accuracy, completeness, or usefulness of any information, apparatus, product, or process disclosed, or represents that its use would not infringe privately owned rights. Reference herein to any specific commercial product, process, or service by trade name, trademark, manufacturer, or otherwise does not necessarily constitute or imply its endorsement, recommendation, or favoring by the United States government or any agency thereof. The views and opinions of authors expressed herein do not necessarily state or reflect those of the United States government or any agency thereof.

Available electronically via www.OSTI.gov.

Available for a processing fee to U.S. Department of Energy and its contractors, in paper, from:

U.S. Department of Energy

Office of Scientific and Technical Information

P.O. Box 62

Oak Ridge, TN 37831-0062

OSTI http://www.osti.gov Phone: 865.576.8401

Fax: 865.576.5728

Email: reports@osti.gov

Available for sale to the public, in paper, from:

U.S. Department of Commerce National Technical Information Service 5301 Shawnee Road Alexandria, VA 22312 NTIS http://www.ntis.gov

Phone: 800.553 .6847 or 703.605 .6000

Fax: 703.605.6900

Email: orders@ntis.gov 


\title{
2018 Offshore Wind Technologies Market Report
}

\author{
Primary Authors \\ Walter Musial, National Renewable Energy Laboratory \\ Philipp Beiter, National Renewable Energy Laboratory \\ Paul Spitsen, U.S. Department of Energy \\ Jake Nunemaker, National Renewable Energy Laboratory \\ Vahan Gevorgian, National Renewable Energy Laboratory
}

List of Figures

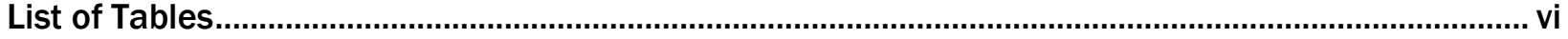

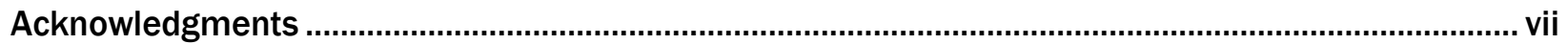

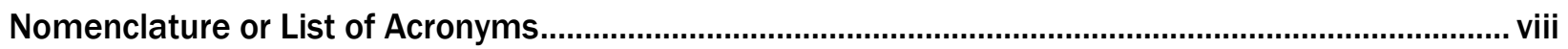

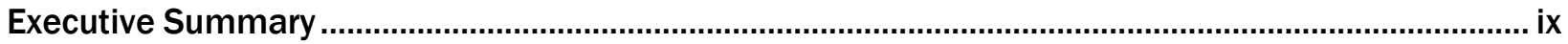

U.S. Offshore Wind Energy Market-Key Findings ........................................................................ ix

Global Offshore Wind Energy Market-Key Findings .................................................................

Offshore Wind Energy Technology Trends-Key Findings.................................................................

Offshore Wind Energy Cost and Price Trends-Key Findings ........................................................ xiv

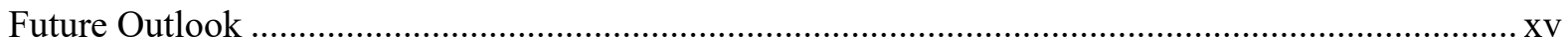

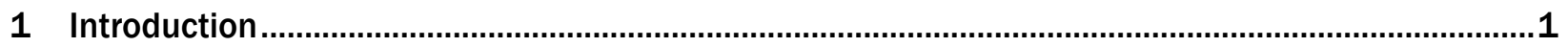

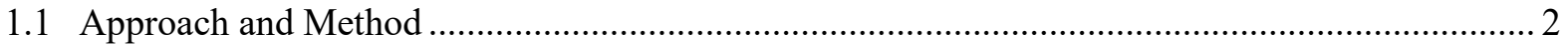

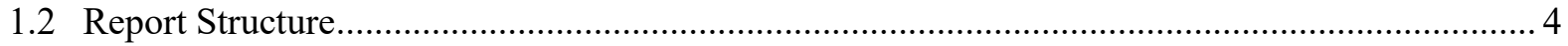

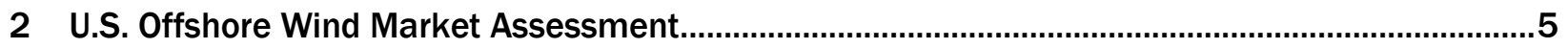

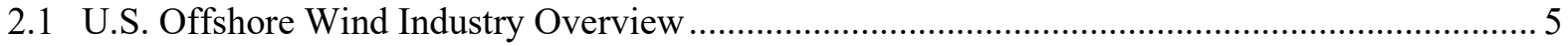

2.2 U.S. Offshore Wind Market Potential and Project Pipeline Assessment ..................................... 5

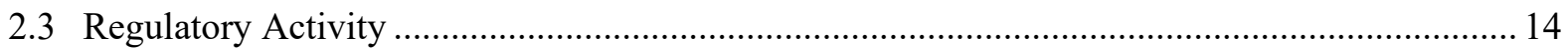

2.4 U.S. Offshore Wind Project Offtake and Policy Assessment...................................................... 17

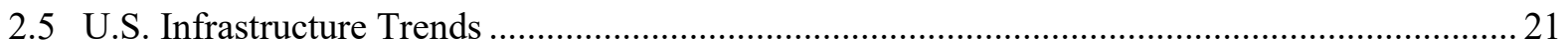

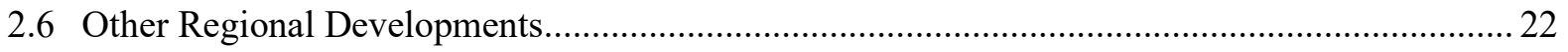

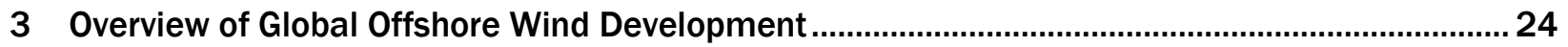

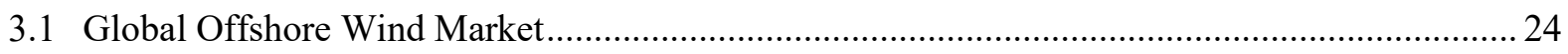

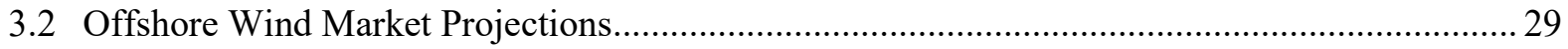

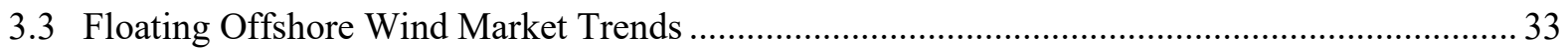

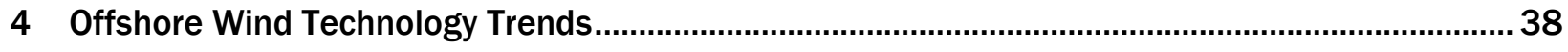

4.1 Siting Trends for Global Offshore Wind Projects .................................................................... 38

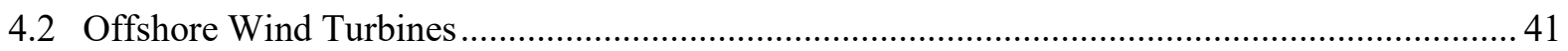

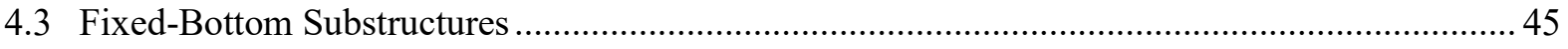




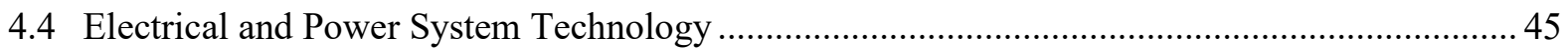

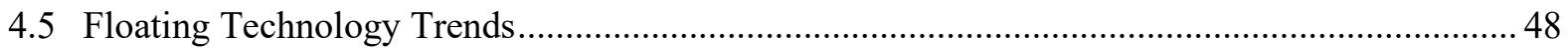

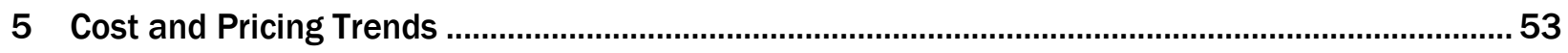

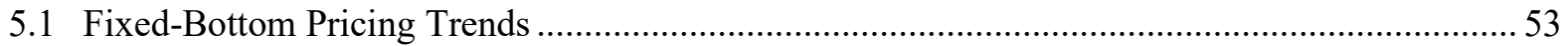

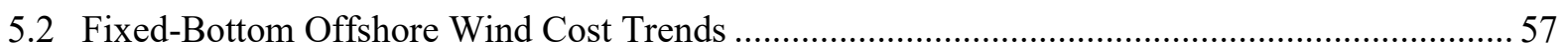

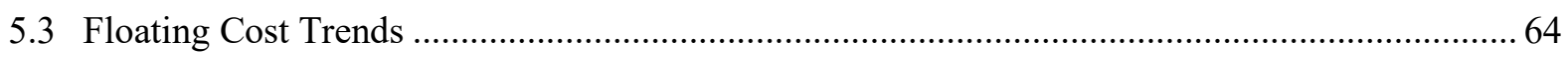

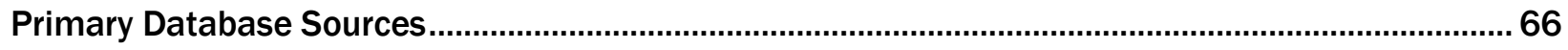

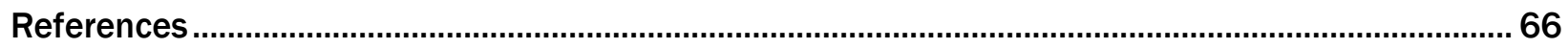

\section{List of Figures}

Figure ES-1. Locations of U.S. offshore wind pipeline activity and Call Areas as of March 2019. Map provided by NREL

Figure ES-2. U.S offshore wind market forecasts for annual additions (left axis) and cumulative

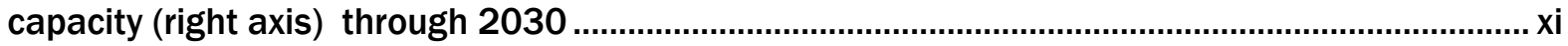

Figure ES-3. A 6-MW floating wind turbine in Equinor's 30-MW array near Peterhead, Scotland. Photo from Walt Musial, NREL ................................................................................................... xiii

Figure ES-4. Adjusted strike prices from European offshore wind auctions ....................................... xiv

Figure 1. Percentages of U.S offshore wind pipeline $(25,824 \mathrm{MW})$ by classification category.............6

Figure 2. U.S. project pipeline classification by state............................................................................

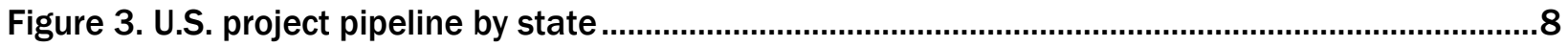

Figure 4. Locations of U.S. Atlantic Coast offshore wind pipeline activity and Call Areas as of March 2019. Map provided by NREL

Figure 5. Locations of U.S. West Coast offshore wind pipeline activity and Call Areas as of March

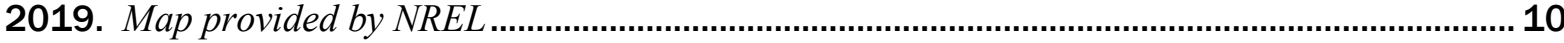

Figure 6. Locations of Hawaiian offshore wind pipeline activity and Call Areas as of March 2019. Map provided by NREL.

Figure 7. U.S offshore wind market forecasts (annual additions-left axis) (cumulative capacity

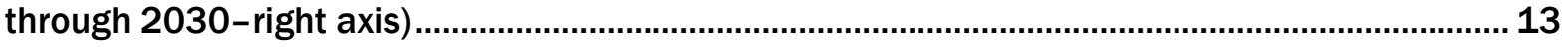

Figure 8. U.S. offshore wind lease sale prices to date by year …….................................................... 15

Figure 9. Global offshore wind in 2018 (annual installed capacity-left axis) (cumulative capacity-

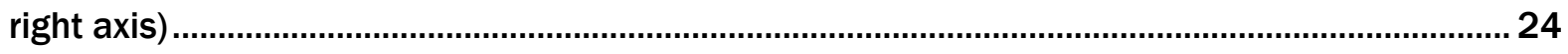

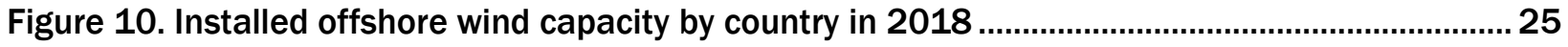

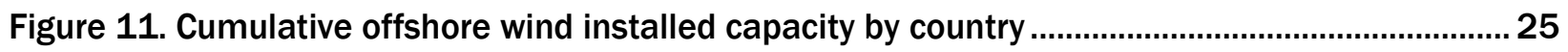

Figure 12. Cumulative installed offshore wind capacity by country over time ...................................26

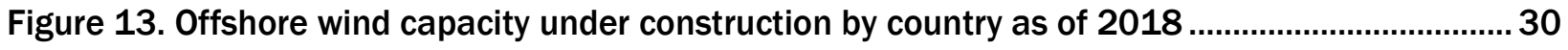


Figure 14. Developer-announced offshore wind capacity through 2024 for projects with financial close

Figure 15. Estimated 2024 cumulative offshore wind capacity by country based on a developerannounced COD (shaded areas represent forecasted deployments).

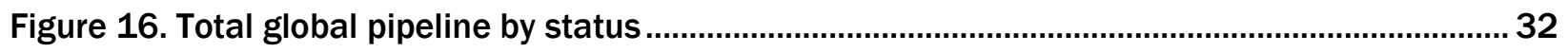

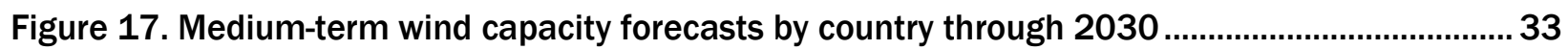

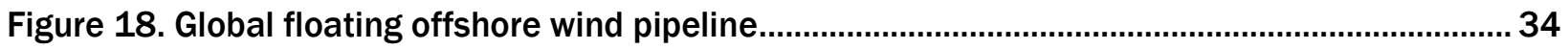

Figure 19. Fixed-bottom offshore wind project depths and distance to shore ...................................38

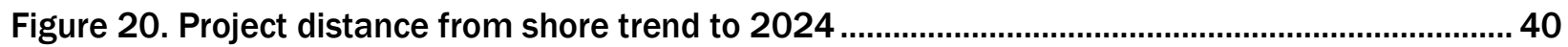

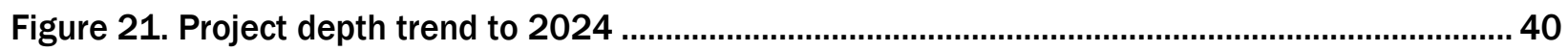

Figure 22. Offshore wind turbine rating, hub height, and rotor diameter......................................... 41

Figure 23. Average commercial offshore wind turbine rating compared to prototype deployment by year.

Figure 24. Offshore wind turbine manufacturers by market share for 2018 (left) and future (right)44

Figure 25. Offshore wind substructure technology trends in 2018.

Figure 26. Number of turbines energized by supplier in 2018. Chart courtesy of WindEurope 2019.46

Figure 27. Share of energized export cables by supplier in 2018. Chart courtesy of WindEurope 2019

Figure 28. Near-shore offshore wind power plant operating with the land-based BESS. Illustration by

NREL

Figure 29. Capacity-weighted average of floating substructure selection for the global pipeline..... 49

Figure 30. A 6-MW floating wind turbine in Equinor's 30-MW array near Peterhead, Scotland, supported by a spar buoy floating platform. Photo courtesy of Walt Musial, NREL

Figure 31. Second-generation floating wind concepts of alternative hybrid substructures. Images courtesy of Stiesdal Offshore Technologies (left) and SBM Offshore (right)

Figure 32. Adjusted strike prices from U.S. and European offshore wind auctions. Reprinted from Beiter et al. (2019)

Figure 33. Global LCOE estimates for fixed-bottom offshore wind

Figure 34. Capital expenditures of global offshore wind projects by commercial operation date and project capacity

Figure 35. Turbine CapEx trend estimates. 60

Figure 36. Global LCOE estimates for floating technology 64 


\section{List of Tables}

Table 1. Offshore Wind Project Pipeline Classification Criteria............................................................. 4

Table 2. U.S. Offshore Wind Pipeline Capacity for Five Categories....................................................6

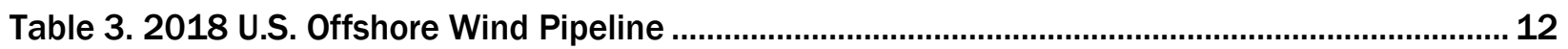

Table 4. BOEM's Massachusetts Offshore Wind Auction Results from December 2018 ................... 14

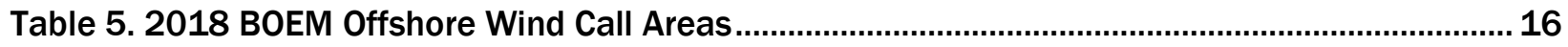

Table 6. U.S. Offshore Wind Offtake Agreements as of June 10, 2019.......................................... 18

Table 7. Current U.S. Offshore Wind State Policies and Activity as of June 10, 2019..................... 19

Table 8. Ports with Recent Investments for the U.S. Offshore Wind Industry .....................................21

Table 9. European Projects Installed and Grid Connected in 2018................................................27

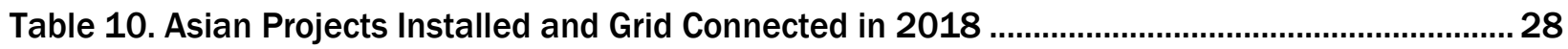

Table 11. Current Floating Offshore Wind Projects in Pipeline .......................................................... 35

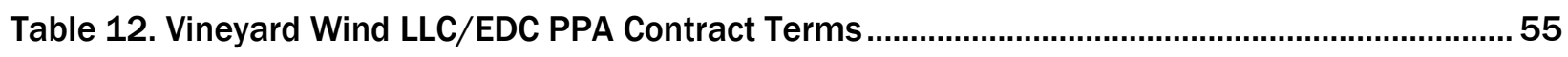

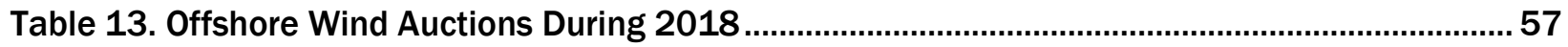

Table 14. Typical Financing Conditions for European Offshore Wind Projects................................... 62

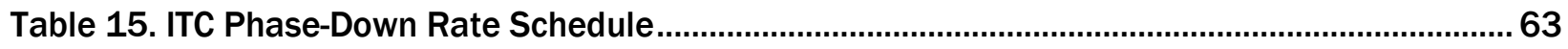




\section{Acknowledgments}

This work was supported by the U.S. Department of Energy (DOE) under Contract No. DE-AC36-08GO28308 with the National Renewable Energy Laboratory (NREL). Funding for the work was provided by the DOE Office of Energy Efficiency and Renewable Energy Wind Energy Technologies Office. The report was reviewed by a diverse group of offshore wind industry stakeholders including four developers, three wind turbine manufacturers, two state government representatives, one nongovernmental organization, seven internal Office of Energy Efficiency and Renewable Energy staff, three NREL management staff, four consultants, and three regulators. The authors would like to extend thanks to Patrick Gilman and Gary Norton (contractor) from the DOE Wind Energy Technologies Office for supporting this research. Thanks also to Valerie Reed, Liz Hartman, Rich Tusing, Dan Beals, and Alana Duerr of the DOE Wind Energy Technologies Office for their support and strategic guidance.

The authors would like to thank the following reviewers and contributors from NREL including Brian Smith, Paul Veers, and Eric Lantz (NREL).

This report covers a wide range of industry projects, policies, and past reports that the authors have documented with extensive support from a diverse group of peer reviewers. These experts and stakeholders include Tom Harries (Bloomberg New Energy Finance), Darryl Francois and Stephen Boutwell (Bureau of Ocean Energy Management), James Glennie (Danish Trade Council/Embassy), Stephanie McClellan (Delaware Special Initiative on Offshore Wind and Renewable Consulting Group and Renewables Consulting Group), Knut Aanstad (Equinor), Albert Fisas (GE), Nils Bolgen (Massachusetts Clean Energy Center), Jason Folsom (MHI Vestas), Nathanael Greene (National Resources Defense Council), Anne Marie McShea (New Jersey Board of Public Utilities), Gavin Smart (ORE Catapult), Kris Ohleth (Ørsted), Aaron Smith and Loris Canizares (Principle Power Inc.), and Fergus Costello and Soeren Daugaard (Siemens Gamesa).

Editing was provided by Sheri Anstedt (NREL) and graphics and cover design were created by John Frenzl (NREL). Additional communications and coordination were provided by Alex Lemke (NREL), Kiki Carpenter (NREL), Tiffany Byrne (NREL), and Carol Laurie (NREL). 


\section{Nomenclature or List of Acronyms}

AC

BESS

BNEF

BOEM

BPU

CapEx

CIP

COD

DOE

EDF

EDPR

EnBW

GW

HVDC

IEC

IRENA

ITC

$\mathrm{kV}$

$\mathrm{km}$

LEEDCo

Berkeley Lab

LCOE

$\mathrm{m}$

MW

MWh

nm

NOAA

NREL

NYSERDA

O\&M

OEM

OpEx

OREC

OWDB

PPI

PPA

REC

RPS

$\mathrm{S}$

SIOW

TBD

WEA alternating current

battery energy storage system

Bloomberg New Energy Finance

Bureau of Ocean Energy Management

Board of Public Utilities

capital expenditures

Copenhagen Infrastructure Partners

commercial operation date

U.S. Department of Energy

Électricité de France Renouvelables

Energias de Portugal Renováeis

Energie Baden-Württemberg AG

gigawatt

high-voltage direct current

International Electrotechnical Commission

International Renewable Energy Agency

investment tax credit

kilovolt

kilometer

Lake Erie Energy Development Corporation

Lawrence Berkeley National Laboratory

levelized cost of energy

meter

megawatt

megawatt-hour

nautical mile

National Oceanic and Atmospheric Administration

National Renewable Energy Laboratory

New York State Energy Research and Development Authority

operation and maintenance

original equipment manufacturer

operational expenditures

offshore renewable energy certificate

offshore wind database

Principle Power Inc.

power purchase agreement

renewable energy certificate

renewables portfolio standard

second

Special Initiative on Offshore Wind

to be determined

wind energy area 


\section{Executive Summary}

Offshore wind energy is a rapidly growing global industry that creates electricity from wind turbines installed in coastal waters on either rigid or floating substructures anchored to the seabed or lake bottom. The 2018 Offshore Wind Technologies Market Report was developed by the National Renewable Energy Laboratory (NREL) with support from the U.S. Department of Energy (DOE) and is intended to provide offshore wind policymakers, regulators, developers, researchers, engineers, financiers, supply chain participants, and other stakeholders with up-to-date quantitative information about the offshore wind market, technology, and cost trends in the United States and worldwide. This report provides detailed information on the domestic offshore wind industry to contextualize the U.S. market and help policymakers, researchers, and the general public understand technical and market barriers and opportunities. Globally, the scope of the report covers the status of the 176 operating offshore wind projects through December 31,2018, and provides the status of, and analysis on, a broader global pipeline of 838 projects in various stages of development. ${ }^{1}$ To provide the most up-to-date discussion of this dynamically evolving industry, this report also tracks the most significant domestic developments and events from January 1, 2018, through March 31, 2019. The following is a summary of the key offshore wind market findings.

\section{U.S. Offshore Wind Energy Market-Key Findings}

The U.S. offshore wind energy project development and operational pipeline ${ }^{2}$ grew to a potential generating capacity of 25,824 megawatts (MW), with $21,225 \mathrm{MW}$ under exclusive site control. ${ }^{3}$ The overall size of the U.S. offshore wind pipeline grew from 25,464 MW to 25,824 MW in 2018-about 1.4\% growth. The 25,824 MW that make up the U.S. offshore wind project development and operating pipeline comprise one operating project (Block Island Wind Farm), eight projects that have reached the permitting phase with either a construction and operations plan or a viable offtake mechanism for sale of electricity, 15 commercial lease areas in federal waters with exclusive site control, two unleased wind energy areas, and five projects (all Pacific-based) that have submitted unsolicited applications to the Bureau of Ocean Energy Management (BOEM) ${ }^{4}$ the government agency that regulates energy development in federal waters. The pipeline has three projects located in state waters, including the operating Block Island Wind Farm, the Aqua Ventus I floating-wind project in Maine, and the Lake Erie Energy Development Corporation Icebreaker Wind project on Lake Erie. In addition, there is one BOEM research lease in Virginia federal waters.

Offshore wind project development and regulatory activities span multiple U.S. regions. Historic development and regulatory activities were concentrated in the North Atlantic region from Virginia northward. New offshore wind activities have been initiated in the Pacific, Great Lakes, and South Atlantic regions as well. In the past, there have been project proposals and leasing activity in the Gulf of Mexico that have been limited to Texas state waters, but in 2018 offshore wind development and regulatory activity in this region was inactive. Figure ES-1 shows a map of offshore wind pipeline activity as of March 31, 2019, as well as BOEM Call Areas, for the entire United States.

\footnotetext{
${ }^{1}$ Note that the 2016 Offshore Wind Technologies Market Report covered operating projects through June 30, 2017, with a focus on developments in 2016 and the first half of 2017 (Musial et al. 2017).

${ }^{2}$ The project development and operational pipeline, commonly referred to as "the pipeline," is represented by the database that the National Renewable Energy Laboratory uses to monitor the progress of the commercial offshore wind industry. It includes sites under development as well as operating projects. In the United States, the pipeline does not include Call Areas because their boundaries are not fixed. Unleased wind energy areas in the United States are included because they have a defined area.

${ }^{3}$ Federal law requires the Bureau of Ocean Energy Management to conduct a fair public auction for offshore wind sites in which there is interest from more than one developer (i.e., "competitive interest"). A developer cannot proceed until they have been awarded exclusive rights to the site through the competitive auction process.

${ }^{4} \mathrm{~A}$ lease area is a parcel of ocean area that is auctioned to prospective developers. Wind energy areas can comprise one or more lease areas. A Call Area is a precursor to a wind energy area.
} 
State-level policy commitments accelerated, driving increased market interest. At the end of 2017, U.S. offshore state wind procurement policies totaled over 5,300 MW targeted for deployment by 2030. By early 2019 , the sum of official state offshore wind capacity commitments increased to 19,968 MW by 2035. In 2018, new commitments were added in Massachusetts (additional 1,600 MW authorized by 2035), New York (6,600 MW added by 2035), and New Jersey (2,400 MW added by 2030), while Connecticut and Rhode Island both agreed to purchase power from Ørsted's 600-MW Revolution project. In 2019, new policy commitments were enacted in Connecticut (2,000 MW) and Maryland (1,200 MW). In some states without offshore-wind-specific targets, like California and Hawaii, 100\% renewables portfolio standards and carbon reduction policies are driving these markets, which are progressing toward the creation of new offshore wind lease areas.
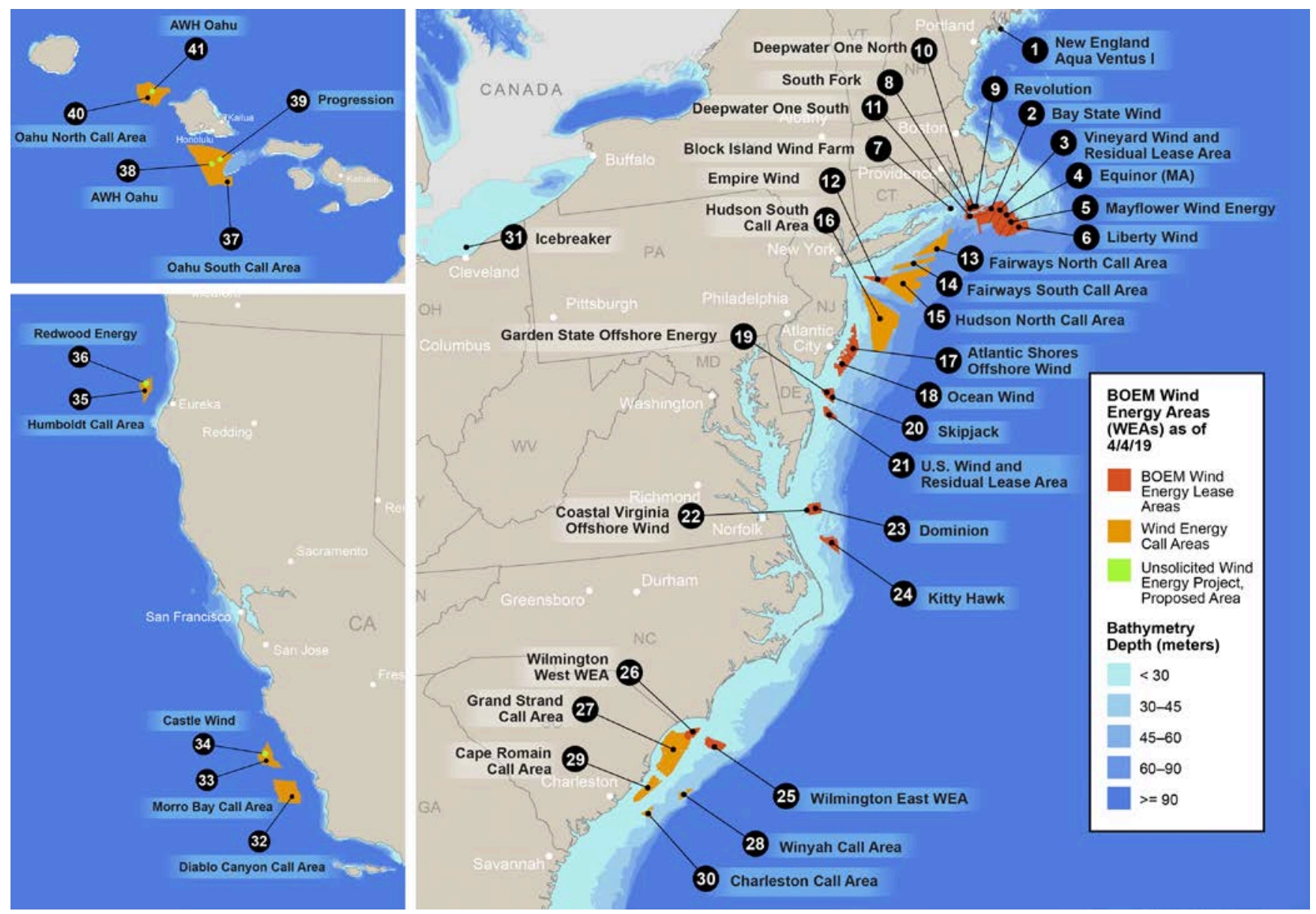

Figure ES-1. Locations of U.S. offshore wind pipeline activity and Call Areas as of March 2019. Map provided by NREL

Increased U.S. market interest spurred strong competition at offshore wind lease auctions. BOEM auctioned a total of 1,573 square kilometers $\left(\mathrm{km}^{2}\right)$, an area about half the size of Rhode Island, in three adjacent offshore wind lease areas off Massachusetts in December 2018. Each winner (Equinor, Mayflower Wind, and Vineyard Wind) submitted a bid of $\$ 135$ million, more than tripling the previous lease area sale price record for a single lease area of $\$ 42$ million in 2016 for the New York lease area submitted by Equinor. Higher offshore wind lease sale prices indicate 1) increased confidence in future market growth driven by state policies, 2) confidence in the regulatory and financial institutions to support offshore wind project development in the nascent U.S. market, 3) continued cost reductions, and 4) heightened demand for offshore wind in the northeastern United States. 
Several U.S. projects advanced in the development process. U.S. offshore wind market progress was more evident from the advancement of major projects in the pipeline in 2018 than the capacity growth of the pipeline. Most notably, the commercial-scale Vineyard Wind project and Ørsted's Revolution project negotiated electricity sale offtake agreements with major electric distribution companies and utilities and took major steps in permitting at both the state and federal level. Overall, in the United States, four projects have submitted construction and operations plans, nine projects have had site assessment plans approved, and six have signed power offtake agreements. Vineyard Wind and South Fork are the most advanced commercialscale U.S. projects, having both obtained a power purchase agreement (PPA) and completed state permits and site surveys, with a construction and operations plan under review by BOEM. Vineyard Wind reports a commercial operation date of 2022 for their Phase 1 facility, consisting of the first $400 \mathrm{MW}$.

Industry forecasts suggest U.S. offshore wind capacity could grow from 11 to 16 gigawatts $(\mathrm{GW})$ by 2030. Figure ES-2 shows three industry forecasts for offshore wind deployment in the United States for the period extending to the year 2030. These estimates were developed by Bloomberg New Energy Finance (BNEF 2018a), 4C Offshore (2018), and University of Delaware's Special Initiative on Offshore Wind (SIOW 2019), ${ }^{5}$ respectively. Together, they illustrate the degree of possible market growth as well as the potential variability associated with future deployment.

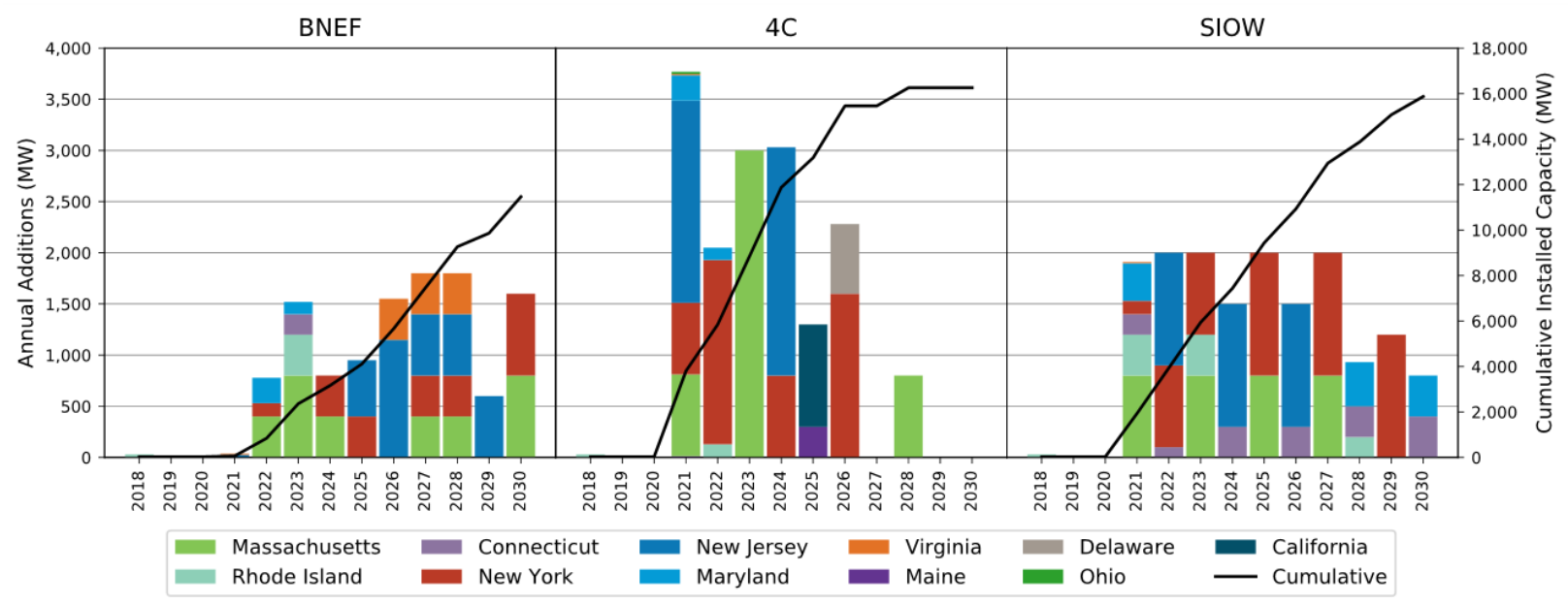

Figure ES-2. U.S offshore wind market forecasts for annual additions (left axis) and cumulative capacity (right axis) through 2030

Offtake prices for the first commercial-scale offshore wind project in Massachusetts were lower than expected. On July 31, 2018, Massachusetts electric distribution companies and Vineyard Wind LLC negotiated a PPA for delivery of offshore-wind-generated electricity at a first-year price of \$74/megawatt-hour (MWh) (2022\$) for Phase 1 (400 MW) and \$65/MWh (2023\$) for Phase 2 (400 MW). An NREL study showed that these PPA prices may not accurately reflect the true cost of the project at face value because other revenue sources, such as the investment tax credit, are not accounted for (Beiter et al. [2019]; see Section 5). Nevertheless, this price was lower than expected given the presumed risks associated with building the first U.S. commercial project with an immature U.S. supply chain. Vineyard Wind's apparent ability to access relatively low-cost financing and take advantage of the waning federal investment tax credit helped them set a competitive benchmark for the U.S. offshore wind industry. The Vineyard Wind PPA price provides a reference point for commercial-scale offshore wind generation in the United States that falls within the price range of European offshore wind projects scheduled to begin commercial operations in the early- to mid2020s. Additional commercial price points are anticipated in New York and New Jersey in 2019.

\footnotetext{
${ }^{5}$ Please note University of Delaware's SIOW forecast is based on the expected date a state selects to procure offshore wind capacity. A 3-year time lag is assumed from the time the procurement occurs until the project becomes fully operational.
} 
Attention to offshore wind in California increased in 2018. California passed Senate Bill 100, The 100 Percent Clean Energy Act of 2018, making it the largest state to establish a 100\% electric renewable energy goal, and setting a carbon-free target year of 2045. Amid continued negotiations with the U.S. Department of Defense, on October 18, 2018, BOEM published a Call for Information and Nominations and received 14 nominations from companies interested in commercial wind energy leases within three proposed Call Areas off central and northern California. All together, these three Call Areas total approximately $2,784 \mathrm{~km}^{2}(687,823$ acres), which could support an offshore-wind-generating capacity for nascent floating wind technology of up to $8.4 \mathrm{GW}$.

New national technical research consortium was launched to spur innovation. DOE has committed \$20.5 million to the New York State Energy Research and Development Authority to form a National Offshore Wind R\&D Consortium. The New York State Energy Research and Development Authority agreed to match the DOE contribution and launched a funding organization to make research and development awards on prioritized topics that will support developers in achieving their near-term deployment and cost targets. The first solicitation was released on March 29, 2019, and the first awards are expected in 2019.

\section{Global Offshore Wind Energy Market-Key Findings}

Globally, industry installed a record 5,652 MW of offshore wind capacity in 2018. Annual capacity additions increased by more than $50 \%$ relative to 2017 . The increase in global generating capacity can be attributed to increased deployment in China, with 2,652 MW of new capacity, followed by 2,120 MW commissioned in the United Kingdom, 835 MW in Germany, 28 MW in Denmark, and about 17 MW divided among the rest of the world. By the end of 2018, cumulative global offshore wind installed capacity grew to 22,592 MW from 176 operating projects. Projections indicate 2019 global capacity additions will be even higher based on projects currently under construction. As of December 31, 2018, the global pipeline for offshore wind development capacity was about 272,000 MW.

The pace of European auctions slowed in the second half of 2018, but forecasts show sustained industry growth. European auction strike prices ${ }^{6}$ in 2018 validated earlier cost reduction trends (see Section 5) but the number of auctions decreased, with only three occurring in the first two quarters of 2018. Adjusted strike prices $^{7}$ for these auctions ranged from $\$ 74 / \mathrm{MWh}$ to $\$ 79 / \mathrm{MWh}$ for commercial-scale projects. The slowdown can be partially attributed to the depletion of viable grid connections in the German markets (Foxwell 2018a). However, long-term forecasts indicate that this trend may be temporary as global offshore wind capacity is projected to reach between 154 and $193 \mathrm{GW}$ by 2030, with more than $50 \%$ coming from Europe (and another major fraction coming from China).

\section{Offshore Wind Energy Technology Trends-Key Findings}

Industry is seeking accelerated cost reductions through larger turbines with rated capacities of $10 \mathrm{MW}$ and beyond. Through technology innovation, turbine original equipment manufacturers have been able to limit the rise in turbine cost (\$/kilowatt) and manage the increase in mass (kilogram/kilowatt) to allow turbine growth to continue upward to at least $12 \mathrm{MW}$, if not $15 \mathrm{MW}$, in the next decade. There are no indications that turbine growth is slowing or has reached a limit for offshore wind. Although the market has experienced a steady upgrade of turbine drivetrain nameplate generating capacity, turbine rotor diameters have grown more slowly. The MHI Vestas V174-9.5 is currently the largest machine in the commercial market (Richard 2019). However, the next generation of turbines promises larger rotors and lower specific power ratings ${ }^{8}$ suited for U.S. offshore markets in the next few years. Specific examples of next-generation turbines include Siemens Gamesa SG 10.0-193DD turbine announced in January 2019, which is planned by Siemens Gamesa to be

\footnotetext{
${ }^{6}$ The strike price for an offshore wind project from an auction is usually the lowest bid price at which the offering can be sold. It usually covers a specific contract term for which that strike price will be paid for the energy produced. The offeror of that strike price is awarded the rights to develop a particular parcel under predetermined conditions set in the tender offer that may vary by country or market. It should not be confused with levelized cost of energy, which may be calculated using different financing and cost assumptions.

${ }^{7}$ The strike prices were adjusted to enable comparisons among projects in different countries to consider a range of possible subsidies and benefits that are available to some projects, such as the cost of the electrical grid connections.

${ }^{8}$ Specific power is the ratio of the nameplate rating of the turbine divided by the rotor's swept area and is given in Watts per meter squared.
} 
market ready by 2022, and the GE Haliade-X 12-MW turbine, which should arrive on the market by 2021 (Siemens 2019; GE 2018b).

Adoption of 66-kV(kilovolt) array cables is increasing to lower electrical infrastructure costs. As the rated power capacity of offshore wind turbines continues to grow, project developers and operators are increasing their use of 66-kV array cable technology instead of the conventional 33-kV systems to connect individual turbines within an array. In 2018, three projects incorporated $66-\mathrm{kV}$ array cables versus only one in 2017. Operation at a higher voltage offers important life cycle cost-efficiency benefits, such as the possibility of reducing the number of offshore substations, decreasing the overall length of installed cables, and minimizing electric losses. During 2018, the 66-kV technology was demonstrated by Nexans in three pilot wind power plant projects: the Blyth Offshore Demonstrator (United Kingdom), Nissum Bredning Vind (Denmark), and Aberdeen Bay (United Kingdom).

\section{The floating wind energy project pipeline is growing, with multiple floating pilot projects advancing.} The global pipeline for floating offshore wind energy reached 4,888 MW in 2018. The pipeline comprises 38 announced projects, including $46 \mathrm{MW}$ of operating projects. The floating offshore wind energy industry is well into a second-generation, multiturbine, precommercial pilot phase. There are 14 projects representing approximately $200 \mathrm{MW}$ that are currently under construction, having achieved either financial close or regulatory approval. These projects are distributed over nine countries. Figure ES-3 shows a turbine in Equinor's 30-MW floating array off the coast of Peterhead, Scotland — the world's first commercial floating wind energy project — which is now operating into its second year.

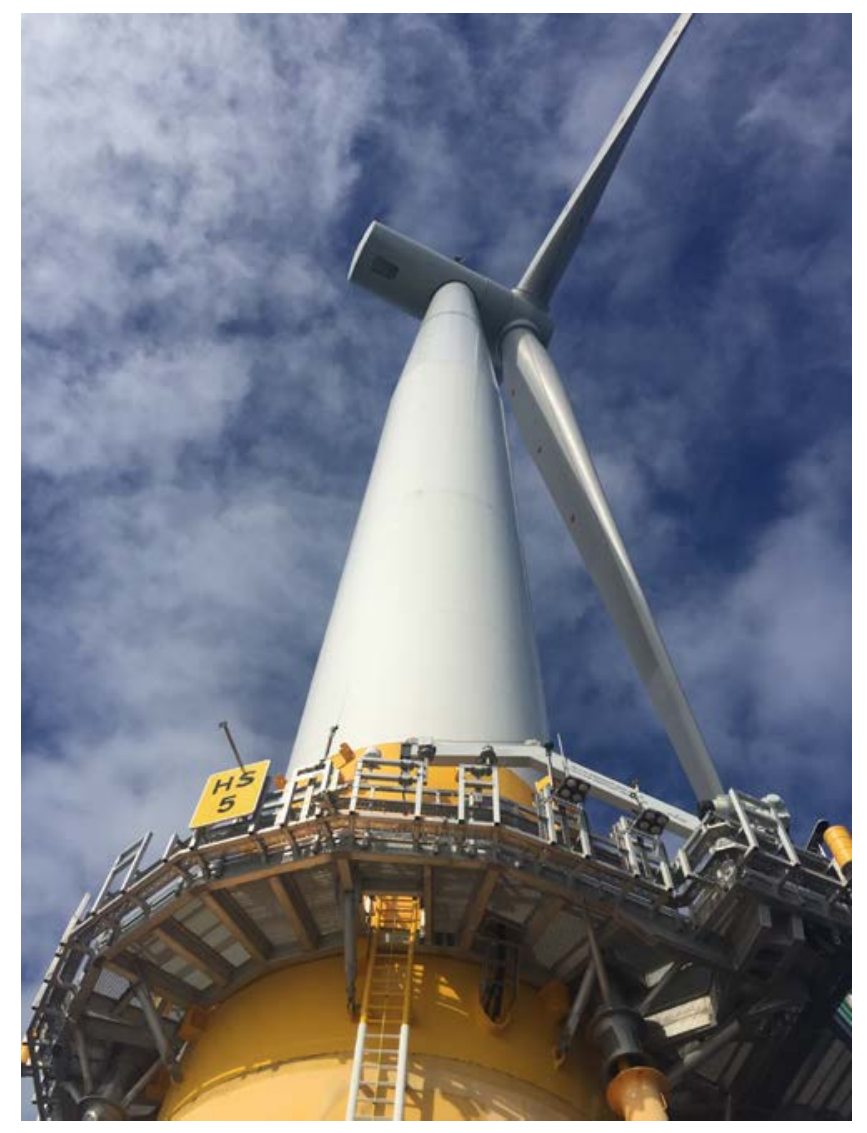

Figure ES-3. A 6-MW floating wind turbine in Equinor's 30-MW array near Peterhead, Scotland. Photo from Walt Musial, NREL 
Semisubmersible substructures dominate the market for floating support structures, but new hybrid platform technologies are being introduced that could compete in future projects. Semisubmersibles, which use buoyancy and the water plane area to achieve stability, make up $94 \%$ of floating projects on a capacity-weighted average because they are inherently a stable buoyant floating substructure with low draft that allows for in-port or nearshore assembly. Several new hybrid technologies (platforms that combine the characteristics of spars, tension-leg platforms and semisubmersibles) are being introduced this year that may rival these substructures. Stiesdal Offshore Technologies's TetraSpar and the SBM tension leg platform are highlighted in Section 4 and may be deployed as early as 2019.

\section{Offshore Wind Energy Cost and Price Trends-Key Findings}

Offshore wind auction strike prices in 2018 validate current cost reduction trends. Prices from European offshore wind auctions and PPAs in 2018 help validate the previously documented trends indicating prices dropping from approximately \$200/MWh for projects beginning operation between 2017 and 2019 to approximately $\$ 75 / \mathrm{MWh}$ for projects beginning operation between 2024 and 2025 . In the United States, Vineyard Wind LLC signed two PPAs with Massachusetts electric distribution companies in July 2018 for a combined $800 \mathrm{MW}$ of offshore wind capacity expected to become operational in 2022 and 2023, respectively. After adjusting for contract type, transmission, policy, and access to external revenue, the Vineyard Wind project has an all-in price of $\$ 98 / \mathrm{MWh}$. The Vineyard Wind price point indicates that U.S. projects may not be subject to a large price premium because of nascent U.S. market structures or a limited domestic supply chain. Figure ES-4 indicates the adjusted Vineyard Wind PPA prices are competitive with European offshore wind prices.

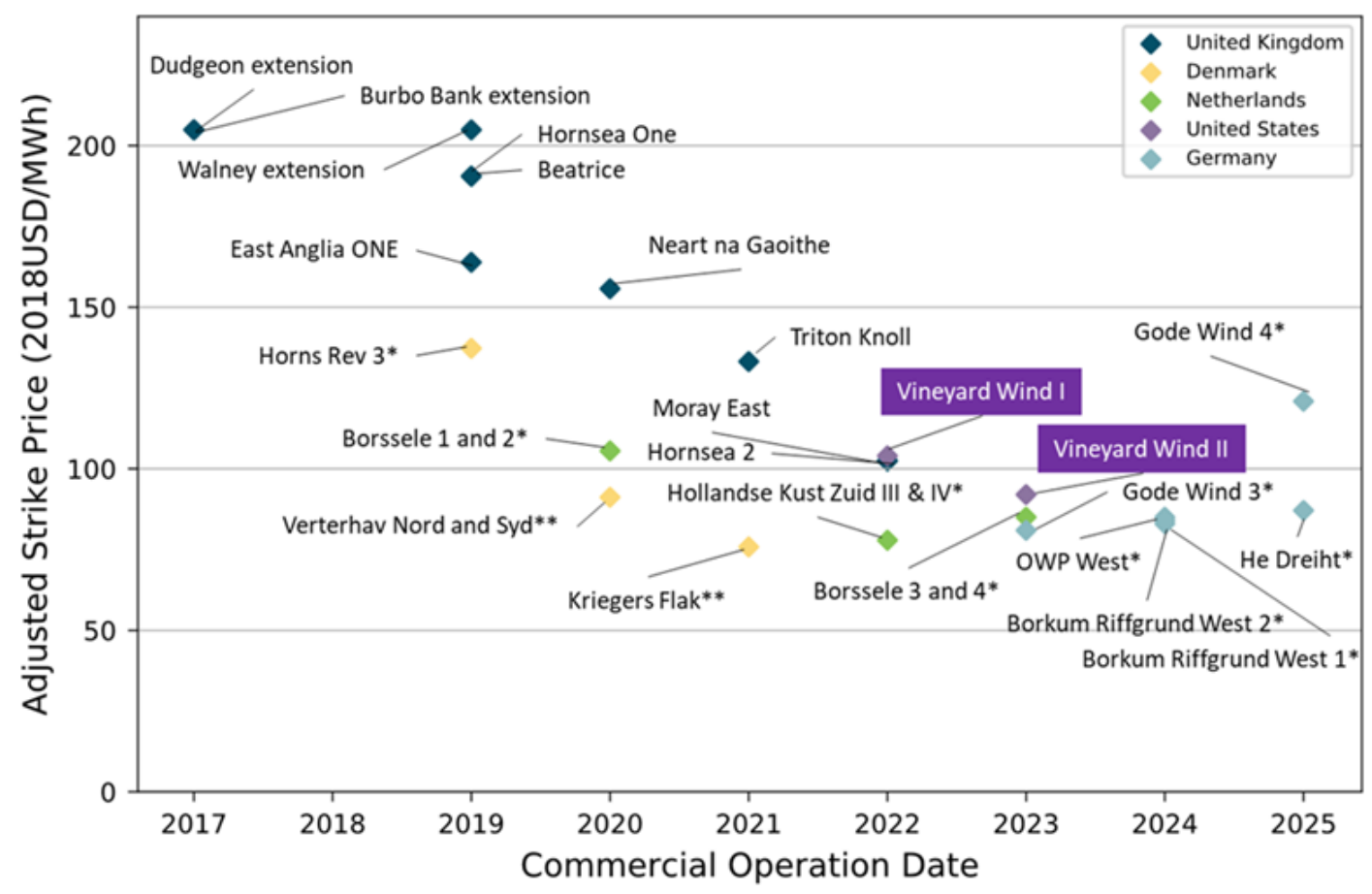

Figure ES-4. Adjusted strike prices from European offshore wind auctions

Sources: 4C Offshore $(2018,2019)$ and Beiter et al. 2019

Notes: * Grid and development costs added; ** Grid costs added and contract length adjusted 


\section{Future Outlook}

Offshore wind market projections show accelerated growth in the next decade, with cumulative capacity ranging from 154 to $193 \mathrm{GW}$ by 2030, and long-range predictions of over $500 \mathrm{GW}$ by 2050 (BNEF 2018a; 4C Offshore 2018; International Renewable Energy Agency 2018). In this context, offshore wind is still at an early stage with respect to the maturity of the technology, supply chain, and infrastructure. The pace of progress and development of the global supply chain is likely to be strongly influenced in the near term by the growth in turbine generating capacity, rising toward $15 \mathrm{MW}$. Although larger turbines improve project costs in the long run, they may also delay industry maturity. It may take several years for the corresponding industrial facilities and infrastructure needed for fabrication, installation, and maintenance to stabilize at ever-increasing turbine scales. This upscaling issue is likely to persist not only in the United States but globally as well.

In the United States, individual states may continue to push for greater commitments for offshore wind, but further declines in offshore wind offtake prices are far from certain in the near term. Offshore wind projects, such as Vineyard Wind, will be able to take advantage of the expiring investment tax credit (see Section 5.1.1.), which will enable low prices (on par with Europe) for the first commercial solicitation in Massachusetts. However, as the investment tax credit expires in 2020, projects will have to make up the difference by raising prices or lowering costs. This may increase the urgency to implement near-term solutions to manage costs, such as developing U.S.-flagged Jones-Act-compliant vessels or accelerating the growth and maturity of the domestic manufacturing supply chain (see Section 4).

If demand for offshore wind energy continues to increase in states along the U.S. Atlantic and Pacific coasts, as it did in 2018, state policy commitments that are now almost $20 \mathrm{GW}$ could exceed the capacity of the available sites. Presently, there is just over $21 \mathrm{GW}$ of capacity in BOEM lease areas where developers have been granted exclusive site control. Additional state policy commitments may create possible site shortages in some regions, which could trigger the development of more lease areas. 


\section{Introduction}

Offshore wind energy is a rapidly growing global industry that creates electricity from large wind turbines installed in coastal waters on either rigid or floating substructures anchored to the seabed or lake bottom. The 2018 Offshore Wind Technologies Market Report was developed by the National Renewable Energy Laboratory (NREL) for the U.S. Department of Energy (DOE) to provide offshore wind policymakers, regulators, developers, researchers, engineers, financiers, and supply chain participants with up-to-date quantitative information about the offshore wind market, technology, and cost trends in the United States and worldwide. This report includes detailed information on the domestic offshore wind industry to provide context to help navigate technical and market barriers and opportunities. It also covers the status of the 176 operating offshore wind projects in the global fleet through December 31, 2018, and provides the status and analysis on a broader global pipeline of 838 projects at varying stages of development. In addition, this report provides a deeper assessment of domestic developments and events through March 31, 2019, for this dynamically evolving industry.

This report includes data, obtained from a wide variety of sources about offshore wind projects that are both operating and under development, to offer current and forward-looking perspectives. It is a companion to the 2018 Wind Technologies Market Report and 2018 Distributed Wind Market Report funded by DOE and written by the Lawrence Berkeley National Laboratory (Berkeley Lab) (Wiser et al. 2019) and Pacific Northwest National Laboratory (Orrell et al. 2019), respectively. The reports cover the status of utility-scale and distributed, land-based wind energy located primarily in the United States, and provide quantitative, independent data for use by the wind industry and its various stakeholders.

Global offshore wind deployment in 2018 set a new record for a single year (5,652 megawatts [MW]), and optimism for the future is high, with long-term industry projections of over 150 gigawatts $(\mathrm{GW})$ by 2030 and over $500 \mathrm{GW}$ by 2050 (Bloomberg New Energy Finance [BNEF] 2018b; 4C Offshore 2018; International Renewable Energy Agency [IRENA] 2018). However, 2018 was somewhat unusual by historical standards as the Chinese market saw its largest deployment ever, with over 2,600 MW of new installations. Offshore wind in Europe installed 2,994 MW, representing about $50 \%$ of the new installed capacity.

The offshore wind market in the United States evolved rapidly in 2018 because of a series of positive global and domestic market growth indicators. After bids for a few offshore wind projects in Europe reinforced developers' confidence of zero-subsidy projects in some markets, the United States also saw low-price signals from its first commercial project. In 2018, the U.S. market logged the first competitive bid for an 800-MW commercial wind power plant-Vineyard Wind — in Massachusetts, which seemed to indicate that European market prices can be achieved in the northeastern United States for projects commissioned as early as 2022 . The possibility of achieving European offshore wind price levels in U.S. waters coincided with a new wave of state policy support for offshore wind, which originally began in 2016, but increased in late 2018 through the present day. Several new states made offshore wind commitments in 2018, whereas several of the alreadycommitted states aggressively increased their commitments (McClellan 2019). In addition, market optimism likely helped drive lease area auction prices to record highs, as observed in the Massachusetts wind energy area (WEA) lease sales in December 2018 (\$135 million per lease area), which were each three times higher than the previous winning lease area bid in New York just 2 years earlier. These record-high prices may indicate a heightened demand for new WEAs as well as an increase in the financial caliber of the bidders, as new members of well-capitalized oil companies and utilities try to establish themselves as offshore wind developers in the emerging U.S. market. All told, the U.S. market developments in 2018 appear to be laying the groundwork for the formation of a new multibillion-dollar offshore wind industry that is likely to bear fruit in the next 5 to 10 years (BNEF 2018a; 4C Offshore 2018; McClellan 2019).

The data and information in this report provide insight into the domestic and global market status, technology trends, and costs, and are key inputs to the annual Cost of Wind Energy Review report, which provides an updated summary of the cost of land-based and offshore wind energy in the United States to support DOE's programmatic reporting on the cost of wind energy (Stehly et al. 2017, 2018). 


\subsection{Approach and Method}

\subsubsection{NREL Offshore Wind Database}

The 2018 Offshore Wind Technologies Market Report uses NREL's internal offshore wind database (OWDB), which contains information on more than 1,700 offshore wind projects located in 49 countries and totaling approximately 623,329 MW of announced project capacity (both active and dormant). The database includes both fully operational projects dating back to 1990 and anticipated future projects that may or may not have announced their commercial operation date (COD). The OWDB contains information on project characteristics (e.g., water depth, wind speed, distance to shore), economic attributes (e.g., project- and component-level costs and performance), and technical specifications (e.g., component sizes and masses). The database also contains information on installation and transport vessels, as well as ports used to support the construction and maintenance of offshore wind projects.

The OWDB is built from internal research using a wide variety of data sources including peer-reviewed literature, press releases, industry news reports, manufacturer specification sheets, subscription-based industry databases, and global offshore wind project announcements. Unless stated otherwise, the data analysis in this report - both globally and domestically — is derived by NREL from the OWDB and reflects the best judgment of the authors and industry subject matter experts that were consulted. To ensure accuracy, NREL verified the OWDB against the following sources:

- The 4C Offshore Wind Database

- The Bureau of Ocean Energy Management (BOEM)

- The WindEurope Annual Market Update

- BNEF's Renewable Energy Project Database

- The University of Delaware's Special Initiative on Offshore Wind (SIOW).

Although the data were validated and harmonized with these other sources, minor differences in their definitions and methodology may cause the data in this report to vary from data reported in other published reports. For example, the method for counting annual capacity additions often varies among different sources, because of terms such as "installed" or "operational," and "first power" or "commercial operation date" are defined differently. NREL considers a project to be commercially operational when all turbines are fully operational and transmitting power to a land-based electricity grid (see Table 1). Data may also vary in quality and are subject to high levels of uncertainty, especially data for future projects that are subject to change based on developer and regulatory requirements. Despite annual variability and potential future project-level uncertainty, longer-term trends reported elsewhere are consistent with long-term market trends in NREL's OWDB.

Cost and pricing data in the OWDB span a lengthy time period and are reported in different currencies. To analyze these data, all information in this report were normalized into 2018 U.S. dollars (USD) by:

- Converting costs and prices to USD, using the exchange rate for the year in which the latest data were reported (United States Treasury Bureau of Fiscal Service 2019)

- Inflating the values, which are in nominal USD after the exchange rate conversion, to 2018 USD using the U.S. Consumer Price Index (United States Department of Labor Bureau of Statistics 2019).

\subsubsection{Classification of Project Status}

The "pipeline" is an offshore wind project development and operating project tracking process, which provides the ability to follow the status of a project from early-stage planning through decommissioning. The primary tracking method is aligned with the regulatory process. All offshore wind projects must navigate through the regulatory process that formally begins when a regulator initiates a leasing process to offer developers the 
opportunity to bid for site control through a competitive lease auction ${ }^{9}$ or when an unsolicited project application is formally submitted. In parallel with the regulatory process is the developer's efforts to characterize the economic viability of the project and its capability for long-term energy production to obtain financing. The parallel regulatory and financing pathways have several dependencies, but information about the regulatory path is more easily accessed in the public domain and is therefore the primary method used to track projects in this report. Therefore, the "pipeline" is defined as the set of all offshore wind projects, beginning with those that have formally entered the regulatory leasing process to bid for site control and development rights through projects that have been decommissioned. If known, information on a project's offtake mechanisms and financial close is specifically reported as well. ${ }^{10}$

Offshore wind projects remain in the pipeline from early-stage planning through the operating and decommissioning phases. In the early stages of a project, the exact project footprints and capacities are not always known, but NREL assumes that all lease areas will eventually be fully developed with an array density of $3 \mathrm{MW} /$ square kilometer $\left(\mathrm{km}^{2}\right)$. This is a common metric for computing the available wind resource over an area but is not meant to be restrictive (Musial et al. 2013, 2016). Some developers may want higher array densities for their lease areas, or conversely, could decide or be required to leave areas undeveloped for various reasons. The pipeline is adjusted when these decisions are publicly announced.

Table 1 describes the system used in this report for classifying and tracking the development of offshore wind projects and that has been used in past DOE-sponsored offshore wind market reports (Smith, Stehly, and Musial 2015; Musial et al. 2017; Beiter et al. 2018). Note that the criteria used in Table 1 also apply to the global project classification, but some differences may not allow for direct comparisons, especially during the earlier stages of planning. This disconnect is mainly because some countries have different methods of establishing "site control."

\footnotetext{
${ }^{9}$ Applies to U.S. projects on the Outer Continental Shelf but varies internationally and in state waters.

${ }^{10}$ The "pipeline" is often measured by the quantity of policy commitments made by states. These figures are tracked separately in Section 2.4.2 and offer a good metric for comparison.
} 
Table 1. Offshore Wind Project Pipeline Classification Criteria

\begin{tabular}{|c|c|c|c|}
\hline Step & Phase Name & Start Criteria & End Criteria \\
\hline 1 & Planning & $\begin{array}{l}\text { Starts when a developer or regulatory agency } \\
\text { initiates the formal site control process }\end{array}$ & $\begin{array}{l}\text { Ends when a developer obtains control of a site (e.g., } \\
\text { through competitive auction or a determination of no } \\
\text { competitive interest in an unsolicited lease area [United } \\
\text { States only]) }\end{array}$ \\
\hline 2 & Site Control & $\begin{array}{l}\text { Begins when a developer obtains site control (e.g., } \\
\text { a lease or other contract) }\end{array}$ & $\begin{array}{l}\text { Ends when the developer files major permit applications } \\
\text { (e.g., a construction and operations plan for projects in the } \\
\text { United States) or obtains an offtake agreement }\end{array}$ \\
\hline 3 & $\begin{array}{l}\text { Permitting = } \\
\text { Site Control }+ \\
\text { Offtake Pathway }\end{array}$ & $\begin{array}{l}\text { Starts when the developer files major permit } \\
\text { applications (e.g., construction and operations plan } \\
\text { or obtains an offtake agreement for electricity } \\
\text { production) }\end{array}$ & $\begin{array}{l}\text { Ends when regulatory entities authorize the project to } \\
\text { proceed with construction and certify its offtake agreement }\end{array}$ \\
\hline 4 & Approved & $\begin{array}{l}\text { Starts when a project receives regulatory approval } \\
\text { for construction activities and its offtake agreement }\end{array}$ & $\begin{array}{l}\text { Ends when sponsor announces a "financial investment } \\
\text { decision" and has signed contracts for construction work } \\
\text { packages }\end{array}$ \\
\hline 5 & Financial Close & $\begin{array}{l}\text { Begins when sponsor announces a financial } \\
\text { investment decision and has signed contracts for } \\
\text { major construction work packages }\end{array}$ & Ends when project begins major construction work \\
\hline 6 & Under Construction & Starts when offshore construction is initiated ${ }^{11}$ & $\begin{array}{l}\text { Ends when all turbines have been installed and the project } \\
\text { is connected to and generating power for a land-based } \\
\text { electrical grid }\end{array}$ \\
\hline 7 & Operating & $\begin{array}{l}\text { Commences when all turbines are installed and } \\
\text { transmitting power to the grid; COD marks the } \\
\text { official transition from construction to operation }\end{array}$ & $\begin{array}{l}\text { Ends when the project has begun a formal process to } \\
\text { decommission and stops feeding power to the grid }\end{array}$ \\
\hline 8 & Decommissioned & $\begin{array}{l}\text { Starts when the project has begun the formal } \\
\text { process to decommission and stops transmitting } \\
\text { power to the grid }\end{array}$ & $\begin{array}{l}\text { Ends when the site has been fully restored and lease } \\
\text { payments are no longer being made }\end{array}$ \\
\hline 9 & On Hold/Cancelled & $\begin{array}{l}\text { Starts if a sponsor stops development activities, } \\
\text { discontinues lease payments, or abandons a } \\
\text { prospective site }\end{array}$ & Ends when a sponsor restarts project development activity \\
\hline
\end{tabular}

\subsection{Report Structure}

The remainder of the report is divided into four sections:

- Section 2 summarizes the status of the offshore wind industry in the United States, providing in-depth coverage on the project development pipeline, regulatory activity, offtake mechanisms, infrastructure trends, and regional developments.

- Section 3 provides an overview of the global offshore wind market. Operational and proposed future projects are tracked by country, status, commercial operation date, and capacity. Developments on international floating offshore wind projects are also covered in detail.

- Section 4 describes offshore wind siting and technology trends focusing on turbine technologies, turbine manufacturers, project performance, fixed-bottom substructures, electrical power, export systems, and floating technologies.

- Section 5 provides insight into global and domestic offshore wind prices, capital and operational costs, and financing trends for both fixed-bottom and floating technologies. This section also compares historical and forecasted future prices between the European and U.S. offshore wind markets.

\footnotetext{
${ }^{11}$ Note that some developers may elect to start construction at an onshore landing area to secure certain subsidies or tax incentives.
} 


\section{U.S. Offshore Wind Market Assessment}

\subsection{U.S. Offshore Wind Industry Overview}

In 2018, the U.S. offshore wind market continued to attract significant attention from the global community, primarily brought on by a large increase in state policy commitments. From the end of 2017 until June 10, 2019, the total offshore wind capacity that was committed by the states nearly quadrupled. At the end of 2017 , U.S. state offshore wind procurement policies required over 5,300 MW of offshore wind by 2030. By June 2019 , the sum of official state offshore wind targets increased to 11,468 MW by 2030 and 19,968 MW by 2035. Even in states without offshore wind procurement targets like California and Hawaii, $100 \%$ renewables portfolio standards (RPS), clean energy, or carbon reduction goals are driving new market activity and the potential development of new offshore wind lease areas.

The U.S. offshore wind project pipeline was $25,824 \mathrm{MW}$ at the end of 2018, remaining relatively constant, with only a $1.4 \%$ increase in total pipeline capacity relative to 2017 . Multiple projects made significant progress with electricity offtake agreements and environmental permitting at both the state and federal level. Currently, nine projects have an offtake agreement or are negotiating offtake terms. State-level procurement goals have increased the attractiveness of the U.S. offshore wind market and encouraged competition between developers at recent BOEM auctions. BOEM's auction of three offshore wind lease areas off Massachusetts in December 2018 established a new lease sale price record of $\$ 135$ million each, more than tripling the previous record of $\$ 42$ million, signaling increased market confidence, higher demand, and the existence of a committed pool of well-capitalized bidders (BOEM 2019a, 2019b). Interest in the Pacific offshore wind markets also continued to grow in 2018 (BOEM 2019c). BOEM issued Calls for Information and Nominations for offshore wind development in California prompted by multiple prospective floating wind developers. In addition, a 20year power purchase agreement (PPA) signed with Vineyard Wind in 2018 revealed a first-year price of \$74/megawatt-hour (MWh) (2022\$) and \$65/MWh (2023\$), respectively (Beiter et al. 2019).

Despite an increasing number of offshore wind projects submitting their construction and operations plans and engaging local suppliers, supply chain investment in the United States was not commensurate with regulatory advancement. There has yet to be a U.S.-flagged installation vessel or any domestic manufacturing centers built. Also, states have not yet engaged significantly in land-based grid planning or transmission infrastructure upgrades necessary to integrate the expected levels of offshore wind power (Lefevre-Marton et al. 2019). Nevertheless, two U.S.-flagged crew transfer vessels are being built, multiple ports received significant investments to upgrade infrastructure, and states have developed portals to connect developers with local suppliers. Moreover, the near-term lag in the development of a robust domestic supply chain may not be a barrier to the first few commercial-scale projects because the European supply chains can serve the U.S. market in the near term. At the same time, delays in the development of the domestic supply chain could force U.S. project costs above European market costs for large-scale commercial deployment in the mid-2020s and beyond. New technical programs sponsored by DOE and others aim to spur innovation and increase industry supply chain activity (New York State Energy Research and Development Authority [NYSERDA] 2019).

\subsection{U.S. Offshore Wind Market Potential and Project Pipeline Assessment}

\subsubsection{U.S. Offshore Wind Pipeline}

As of December 31, 2018, NREL estimates the U.S. offshore wind pipeline to be 25,824 MW of capacity, which is based on the sum of current installed projects, existing lease areas, unleased WEAs, and unsolicited project applications. Table 2 shows the U.S. market broken into five segments by capacity. The U.S. pipeline capacity has one operational project $(30 \mathrm{MW}), 15$ lease areas where developers have site control (estimated 19,151 MW), two unleased WEAs (estimated 2,250 MW), and five unsolicited project applications (2,350 MW). Only installed projects (30 MW) and projects with site control that have advanced through the initial permitting process and are negotiating offtake agreements $(2,043 \mathrm{MW})$ use actual developer-specified capacity values. This is roughly $8 \%$ of the total capacity, or $2,073 \mathrm{MW}$. These projects have a clear project plan and a site boundary that has been specified including much of the design details. 
The rest of the pipeline capacity in the other three categories-lease areas with site control, unleased WEAs, and unsolicited project applications - are all estimations based on the potential of the lease area using a capacity density function of $3 \mathrm{MW} / \mathrm{km}^{2}$ (Musial et al. 2016). Therefore, these estimated values are likely to change over time as project parameters are defined more precisely and lease areas are converted from an unspecified or residual area to actual project capacity. Figure 1 shows each of those categories as a percent of the total U.S. pipeline.

Table 2. U.S. Offshore Wind Pipeline Capacity for Five Categories

\begin{tabular}{|c|c|c|c|}
\hline & Status & Description & Capacity \\
\hline 1 & Installed & $\begin{array}{l}\text { The project is fully operational with all turbines generating power to } \\
\text { the grid. }\end{array}$ & $30 \mathrm{MW}$ \\
\hline 2 & $\begin{array}{l}\text { Projects Permitting } \\
\text { with Site Control } \\
\text { and Offtake } \\
\text { Pathway }\end{array}$ & $\begin{array}{l}\text { The developer has site control and has initiated permitting processes } \\
\text { to construct the project and sell its power. }\end{array}$ & $2,043 \mathrm{MW}$ \\
\hline 3 & $\begin{array}{l}\text { Lease Areas with } \\
\text { Site Control }\end{array}$ & $\begin{array}{l}\text { Developer has acquired the rights to a lease area. Capacity is } \\
\text { estimated using a turbine density of } 3 \mathrm{MW} / \mathrm{km}^{2} \text {. Depending on market } \\
\text { demand, developers may or may not incrementally build out projects } \\
\text { to use a given lease area's entire size/potential. }\end{array}$ & $\begin{array}{l}19,151 \mathrm{MW} \\
\text { (Estimated) }\end{array}$ \\
\hline 4 & $\begin{array}{l}\text { Unleased Wind } \\
\text { Energy Areas }\end{array}$ & $\begin{array}{l}\text { The rights to lease areas have yet to be auctioned to developers. } \\
\text { Capacity is estimated using a } 3 \mathrm{MW} / \mathrm{km}^{2} \text { turbine density function. }\end{array}$ & $\begin{array}{l}2,250 \mathrm{MW} \\
\text { (Estimated) }\end{array}$ \\
\hline 5 & $\begin{array}{l}\text { Unsolicited Project } \\
\text { Applications }\end{array}$ & $\begin{array}{l}\text { Developer lacks site control but has submitted a project proposal to } \\
\text { BOEM. Project application capacities estimated using a 3-MW/km² } \\
\text { density and project footprint size identified in the proposal. }\end{array}$ & $\begin{array}{l}2,350 \mathrm{MW} \\
\text { (Estimated) }\end{array}$ \\
\hline & & Total & 25,824 MW \\
\hline
\end{tabular}

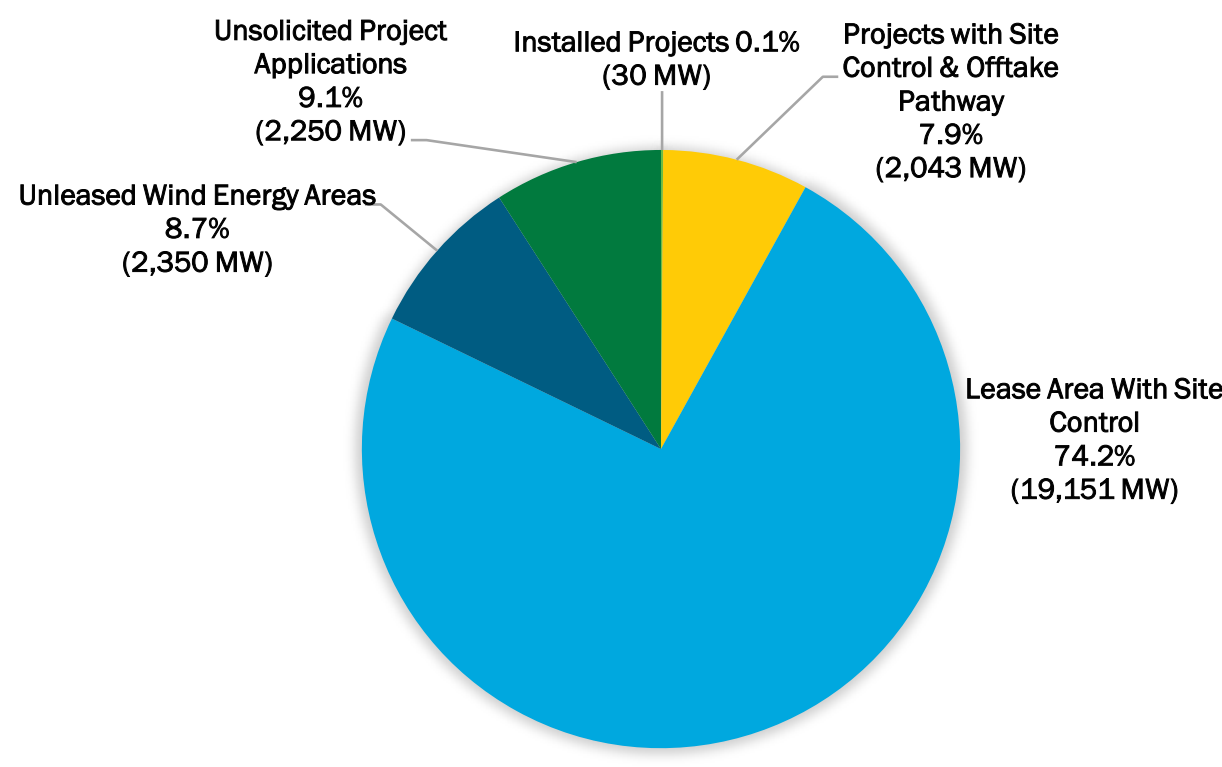

Figure 1. Percentages of U.S offshore wind pipeline $(25,824 \mathrm{MW})$ by classification category 
Figure 2 shows the U.S. pipeline activity as of June 10, 2019, for all categories shown in Table 1 by state. ${ }^{12}$ Breaking down the 2018 U.S. pipeline by project status: one project (30 MW) has been installed; nine projects (2,043 MW) have site control, made major permitting progress, or secured a power offtake contract or have a viable pathway to obtaining one; developers have the rights to possibly develop projects in 15 lease areas with a technical potential of 19,151 MW; two unleased WEAs have the potential to support 2,250 MW; and six unsolicited project applications (2,350 MW) may be developed but must comply with BOEM's competitive leasing processes. Projects progressing through offtake and permitting approval processes continued to be primarily located in the northeast United States, where state-level procurement drives the market and project development. However, there is also an increased interest in developing floating projects along the Pacific Coast, as described in Section 2.3.2.

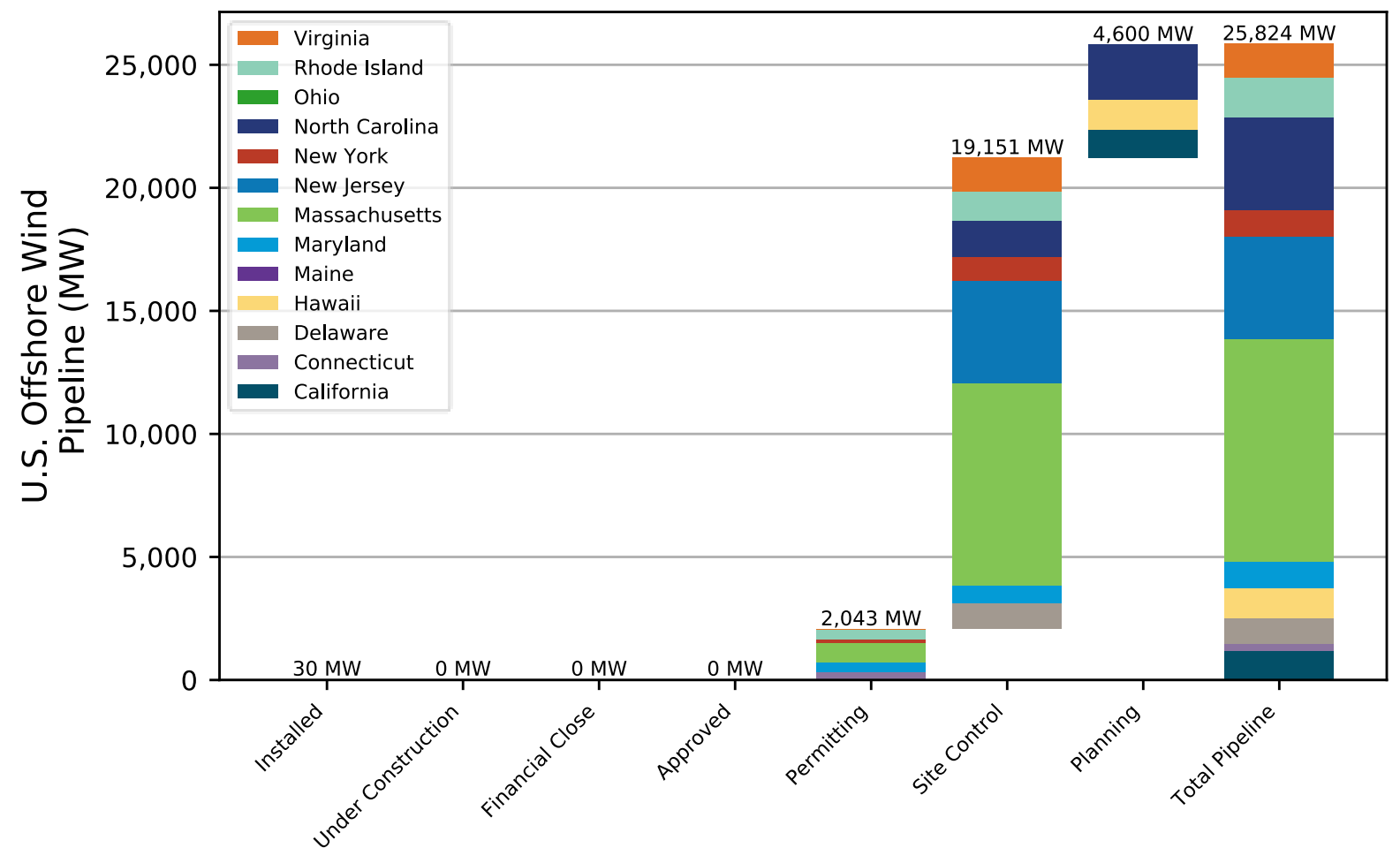

Pipeline Classification

Figure 2. U.S. project pipeline classification by state ${ }^{13}$

There were only minor changes in NREL's estimation of the U.S. offshore wind pipeline from 2017 to 2018 (reporting 25,464 MW in 2017 [Beiter et al. 2018]). The cancellation of the Nautilus Offshore Wind Project in New Jersey accounted for a 24-MW reduction; the expansion of South Fork from $90 \mathrm{MW}$ to $130 \mathrm{MW}$ shifted $40 \mathrm{MW}$ from the Deepwater One North lease area; the Redwood Coast Offshore Wind Project in California added $150 \mathrm{MW}$; and the proposed Castle Wind Project in California increased its capacity from $765 \mathrm{MW}$ to $1,000 \mathrm{MW}$. All told, the pipeline only increased by a slight $1.4 \%$.

\footnotetext{
${ }^{12}$ State in Figure 2 refers to the state the project intends to sell its power to. If a project has not signed an offtake agreement, the state refers to its physical location.

${ }^{13}$ The location of the project is defined by where the project's power is intended to be sold. If the project does not have an offtake agreement, the location is its physical location. This clarification is needed where projects are located in a certain location but sell their power to a neighboring state market.
} 
Figure 3 provides a different breakdown of the U.S. pipeline by state. From the chart, Massachusetts, New Jersey, and North Carolina possess the most offshore wind potential ${ }^{14}$ as of March 31, 2019. Note that the hashed bars on the chart indicate the pipeline capacity that was estimated on a $3 \mathrm{MW} / \mathrm{km}^{2}$ area basis and the solid (green) colored bars are specific projects.

It is important to be cautious about interpreting these geographic lease areas that have been assigned to specific states, because their physical location does not indicate where the offshore wind power will ultimately be delivered. For example, power from Massachusetts can feasibly be delivered to New York and vice versa. In this sense, projects being developed in nearby WEAs may sell power and other grid services to adjacent states because of market demand, state-level offtake policies, or other factors. Current projects in the pipeline that plan to sell power to neighboring markets include:

- Revolution Wind in the Rhode Island/Massachusetts WEA is planning to deliver power to both Connecticut and Rhode Island

- South Fork in the Rhode Island/Massachusetts WEA is planning to deliver power to Long Island New York

- Skipjack in the Delaware WEA is planning to deliver power to the Delmarva grid in Maryland.

Accordingly, state policy may be a more important driver in determining what projects move forward and which markets they serve than the physical location of the leases.

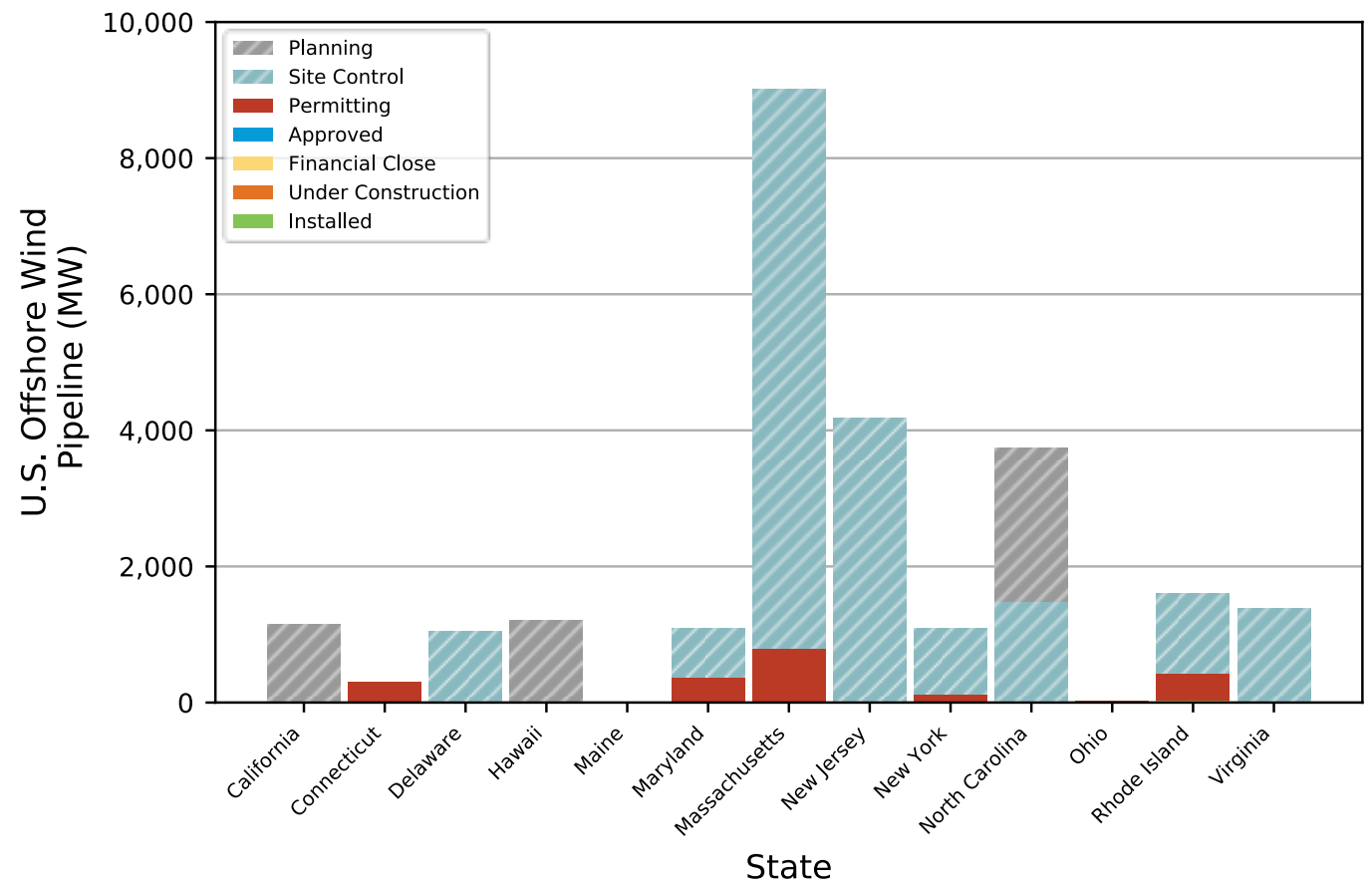

Figure 3. U.S. project pipeline by state ${ }^{15}$

\footnotetext{
${ }^{14}$ Offshore wind potential estimates are made with a significant amount of uncertainty. Uncertainty comes from future market demand, assumed density function, and regulatory proceedings.

${ }^{15}$ The location of the project is defined by where the project's power is sold to. If the project does not have an offtake agreement, the location is the project's physical location. This clarification is needed for projects located in a state's WEA that sells their power to a neighboring state market.
} 
All of the 25,824 MW that make up the U.S. offshore wind pipeline in the United States are itemized as an individual project or project opportunity in Table 3, and in the maps shown in Figures 4, 5, and 6, corresponding to the eastern Atlantic Coast (and Great Lakes ${ }^{16}$ ), California Coast, and Hawaii, respectively.

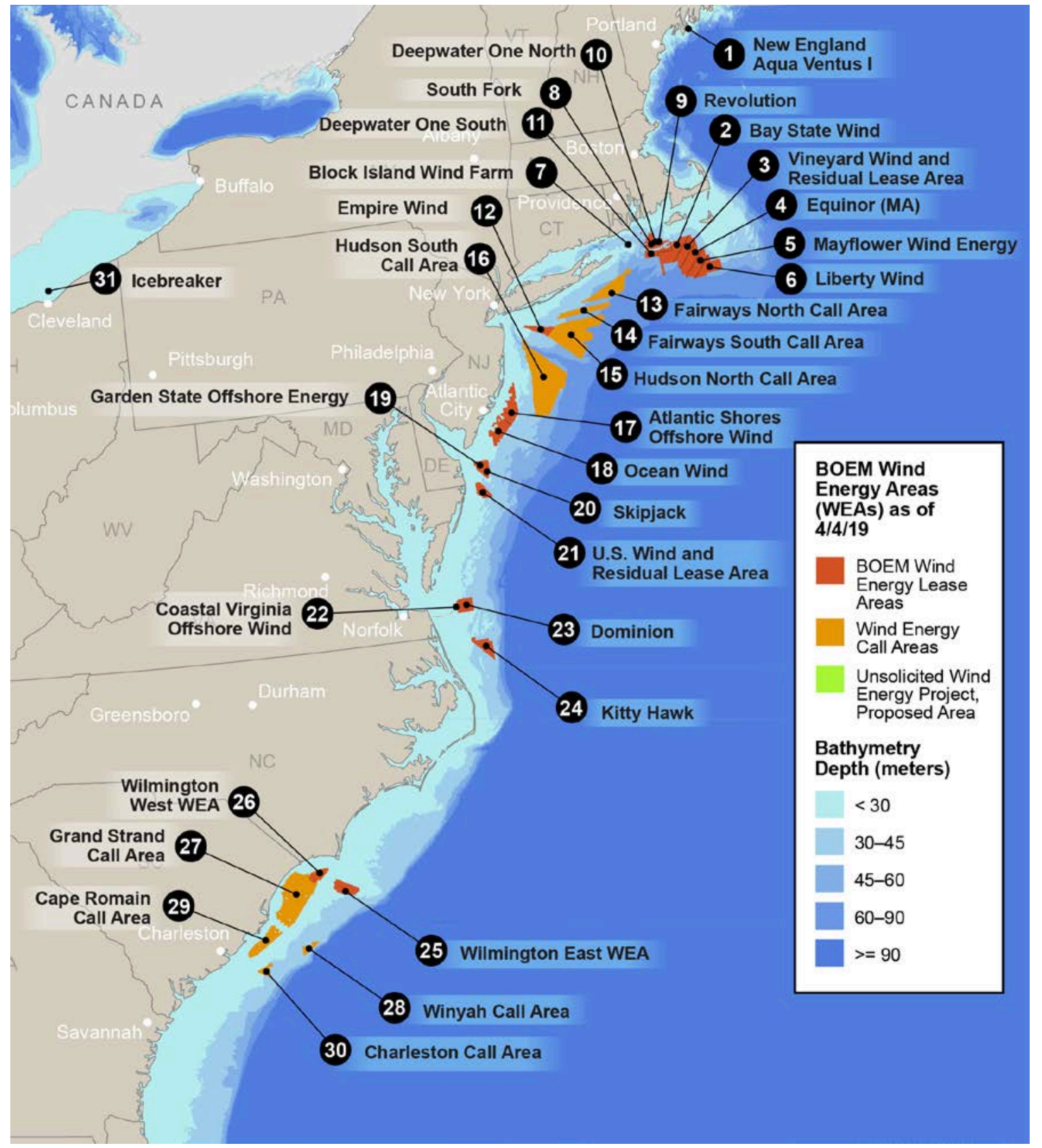

Figure 4. Locations of U.S. Atlantic Coast offshore wind pipeline activity and Call Areas as of March 2019. Map provided by NREL

Most activity is concentrated in the North Atlantic region (Figure 4), but the pipeline activities extend to the Pacific, Great Lakes, and South Atlantic regions. Although there is interest in offshore wind development in the Gulf of Mexico, proposed projects and leasing activities have remained inactive since 2014.

\footnotetext{
${ }^{16}$ Please note the Great Lakes are outside BOEM's jurisdiction.
} 


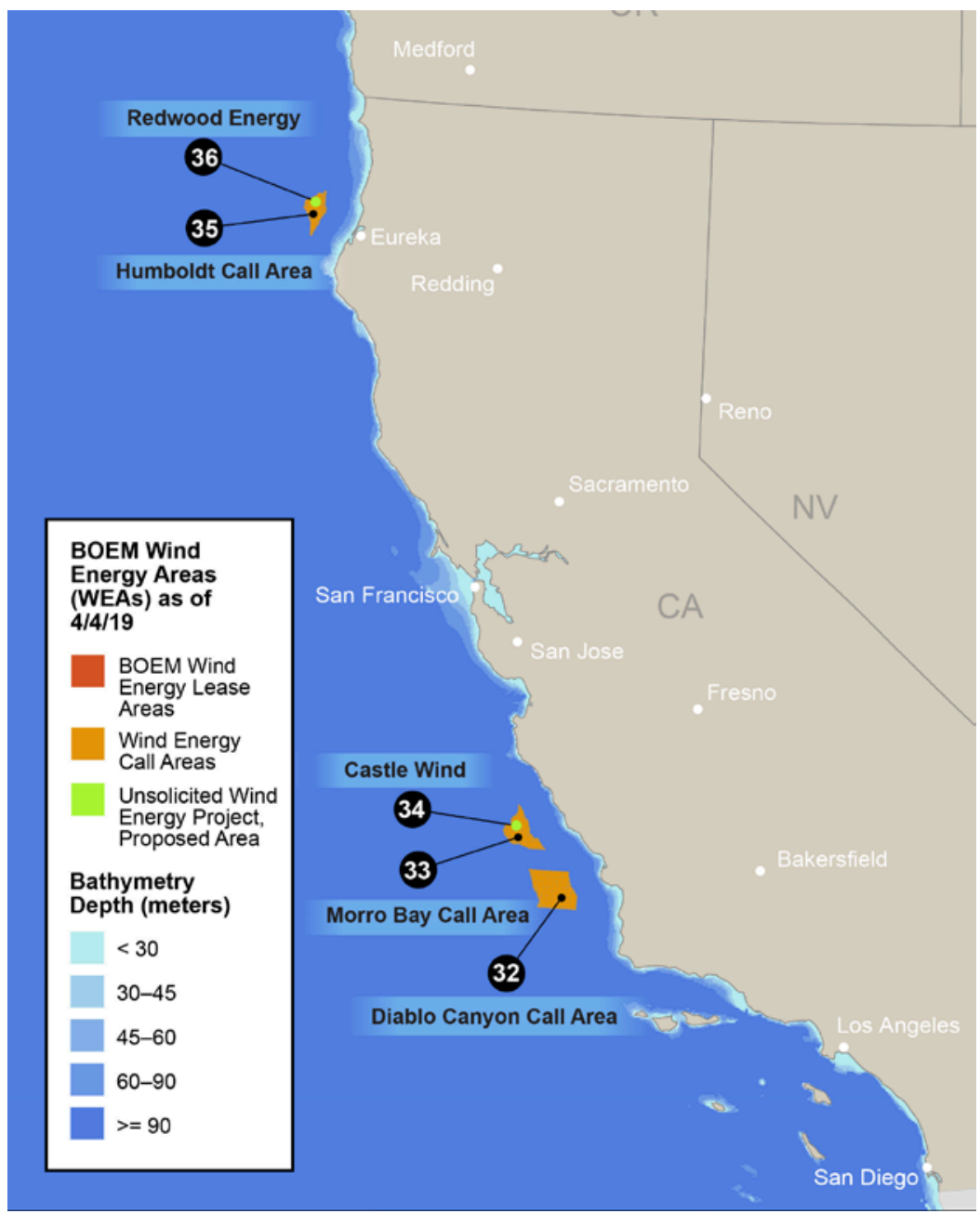

Figure 5. Locations of U.S. West Coast offshore wind pipeline activity and Call Areas as of March 2019. Map provided by NREL

In addition, Table 3 includes 13 Call Areas ${ }^{17}$ that are located in three regions, but the capacity of the Call Areas is not calculated or counted in the total pipeline capacity because Call Areas are too preliminary and likely to change in size and location. In total, there are 41 sites in the United States (as shown on the maps) where there is significant offshore wind development activity. The $25,824 \mathrm{MW}$ of pipeline activity comprises one operating project (Block Island Wind Farm), nine projects at the permitting phase with an offtake strategy, 15 lease areas with exclusive site control, two unleased WEAs, and five projects (all Pacific-based) that have submitted unsolicited applications to BOEM (BOEM 2019c, 2019d). The pipeline has three projects located in state waters, including the operating Block Island Wind Farm in Rhode Island, New England Aqua Ventus I in Maine, and the Lake Erie Energy Development Corporation (LEEDCo) Icebreaker project located in Lake Erie, just north of Cleveland. Both Aqua Ventus and Icebreaker were originally funded under the DOE Advanced Technology Demonstration Project program, which began in 2012 (DOE 2019). As a result, they have advanced further in the permitting process than many other projects, having acquired most site approvals from their respective states and establishing reasonable pathways to finalize their PPAs.

\footnotetext{
${ }^{17}$ BOEM periodically issues calls for information and nominations (Call Areas) to obtain public and developer feedback on what ocean areas may be suitable for future commercial offshore wind development.
} 


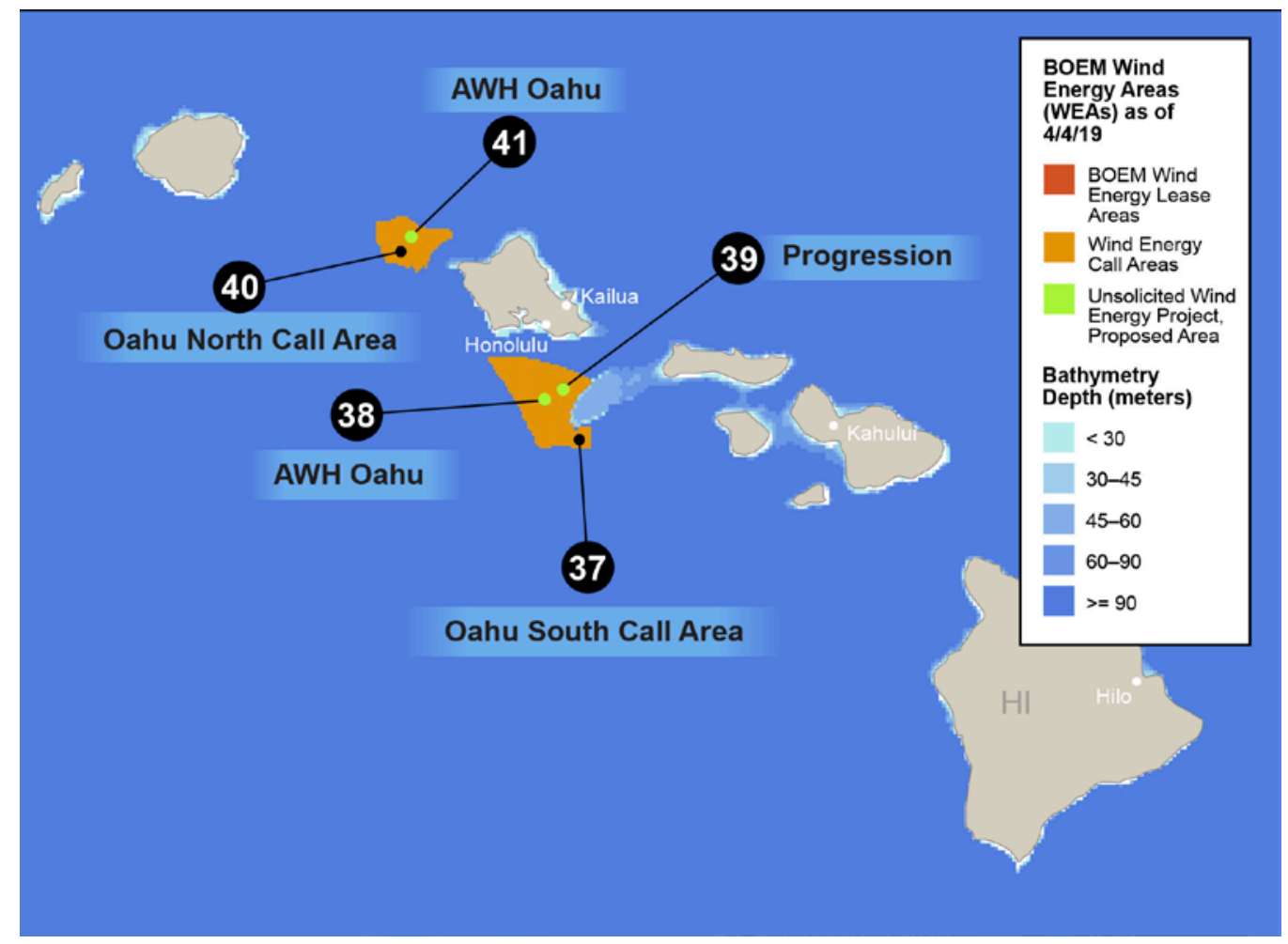

Figure 6. Locations of Hawaiian offshore wind pipeline activity and Call Areas as of March 2019. Map provided by NREL 
Table 3. 2018 U.S. Offshore Wind Pipeline

\begin{tabular}{|c|c|c|c|c|c|c|c|c|c|c|c|}
\hline$\#$ & Location $^{1}$ & Project Name ${ }^{2}$ & Status & $\mathrm{COD}^{3}$ & $\begin{array}{c}\text { Announced } \\
\text { Capacity } \\
(\mathrm{MW})^{4}\end{array}$ & $\begin{array}{c}\text { Lease } \\
\text { Area } \\
\text { Potential } \\
(\mathrm{MW})^{5}\end{array}$ & $\begin{array}{c}\text { Pipeline } \\
\text { Capacity } \\
(\mathrm{MW})^{6}\end{array}$ & Lease Area & $\begin{array}{c}\text { Size } \\
\left(\mathrm{km}^{2}\right)^{7}\end{array}$ & $\begin{array}{l}\text { Offtake } \\
\text { (MW) }\end{array}$ & Developer(s) \\
\hline 1 & ME & New England Aqua Ventus I & Permitting & 2022 & 12 & 0 & 12 & State Lease & 9 & ME-12 & Aqua Ventus \\
\hline 2 & MA & Bay State Wind & Site Control & - & 0 & 2,277 & 2,277 & OCS-A 0500 & 759 & TBD & $\varnothing$ rsted/Eversource \\
\hline 3 & MA & Vineyard Wind + Residual ${ }^{8}$ & Permitting & 2023 & 800 & 1,225 & 2,025 & OCS-A 0501 & 675 & MA- 800 & Avangrid/CIP \\
\hline 4 & MA & Equinor (MA) & Site Control & - & 0 & 1,564 & 1,564 & OCS-A 0520 & 521 & TBD & Equinor \\
\hline 5 & MA & Mayflower Wind Energy & Site Control & - & 0 & 1,547 & 1,547 & OCS-A 0521 & 516 & TBD & EDPR/Shell \\
\hline 6 & MA & Liberty Wind & Site Control & - & 0 & 1,607 & 1,607 & OCS-A 0522 & 536 & TBD & Avangrid/CIP \\
\hline 7 & $\mathrm{RI}$ & Block Island Wind Farm & Installed & 2016 & 30 & 0 & 30 & State Lease & 10 & RI-30 & $\varnothing$ rsted/Eversource \\
\hline 8 & RI & South Fork & Permitting & 2022 & 130 & 0 & 130 & OCS-A 0486 & & NY-130 & Ørsted/Eversource \\
\hline 9 & RI & Revolution & Permitting & 2023 & 700 & 0 & 700 & OCS-A 0486 & 395 & $\begin{array}{l}\text { CT-300 } \\
\text { RI-400 }\end{array}$ & Ørsted/Eversource \\
\hline 10 & $\mathrm{RI}$ & Deepwater ONE North & Site Control & - & 0 & 355 & 355 & OCS-A 0486 & & TBD & Ørsted/Eversource \\
\hline 11 & RI & Deepwater ONE South & Site Control & - & 0 & 816 & 816 & OCS-A 0487 & 272 & TBD & Ørsted/Eversource \\
\hline 12 & NY & Empire Wind & Site Control & - & 0 & 963 & 963 & OCS-A 0512 & 321 & TBD & Equinor \\
\hline 13 & NY & Fairways North & BOEM Call Area & - & - & - & - & N/A & - & - & - \\
\hline 14 & NY & Fairways South & BOEM Call Area & - & - & - & - & N/A & - & - & - \\
\hline 15 & NY & Hudson North & BOEM Call Area & - & - & - & - & N/A & - & - & - \\
\hline 16 & NY & Hudson South & BOEM Call Area & - & - & - & - & N/A & - & - & - \\
\hline 17 & $\mathrm{NJ}$ & $\begin{array}{l}\text { Atlantic Shores Offshore } \\
\text { Wind }\end{array}$ & Site Control & - & 0 & 2,226 & 2,226 & OCS-A 0499 & 742 & TBD & EDF/Shell \\
\hline 18 & NJ & Ocean Wind & Site Control & - & 0 & 1,947 & 1,947 & OCS-A 0498 & 649 & TBD & $\varnothing$ rsted \\
\hline 19 & $\mathrm{DE}$ & $\begin{array}{c}\text { Garden State Offshore } \\
\text { Energy }\end{array}$ & Site Control & - & 0 & 1,050 & 1,050 & OCS-A 0482 & 284 & TBD & Ørsted \\
\hline 20 & DE & Skipjack & Permitting & 2023 & 120 & 0 & 120 & OCS-A 0519 & 107 & MD-120 & $\varnothing$ rsted \\
\hline 21 & MD & US Wind + Residual ${ }^{8}$ & Permitting & 2023 & 248 & 718 & 966 & OCS-A 0490 & 322 & MD-248 & US Wind \\
\hline 22 & VA & $\begin{array}{c}\text { Coastal Virginia Offshore } \\
\text { Wind }\end{array}$ & Permitting & 2022 & 12 & 0 & 12 & OCS-A 0497 & 9 & VA-12 & $\begin{array}{c}\varnothing \text { rsted/Dominion } \\
\text { Energy }\end{array}$ \\
\hline 23 & VA & Dominion & Site Control & - & 0 & 1,371 & 1,371 & OCS-A 0483 & 457 & TBD & Dominion Energy \\
\hline 24 & NC & Kitty Hawk & Site Control & - & 0 & 1,485 & 1,485 & OCS-A 0508 & 495 & TBD & Avangrid \\
\hline 25 & NC & Wilmington East WEA & Unleased $^{9}$ & - & 0 & 1,623 & 1,623 & N/A & 209 & - & - \\
\hline 26 & $\mathrm{NC}$ & Wilmington West WEA & Unleased $^{9}$ & - & 0 & 627 & 627 & N/A & 541 & - & - \\
\hline 27 & SC & Grand Strand & BOEM Call Area & - & - & - & - & N/A & - & -- & - \\
\hline 28 & SC & Winyah & BOEM Call Area & - & - & - & - & N/A & - & - & - \\
\hline 29 & SC & Cape Romain & BOEM Call Area & - & - & - & - & N/A & - & - & - \\
\hline 30 & SC & Charleston & BOEM Call Area & - & - & - & - & N/A & - & - & - \\
\hline 31 & $\mathrm{OH}$ & Icebreaker & Permitting & 2022 & 21 & 0 & 21 & State Lease & 10 & $\mathrm{OH}-21$ & LEEDCo/Fred Olsen \\
\hline 32 & $\mathrm{CA}$ & Diablo Canyon & BOEM Call Area & - & - & - & - & - & - & - & - \\
\hline 33 & $\mathrm{CA}$ & Morro Bay & BOEM Call Area & - & - & - & - & - & - & - & - \\
\hline 34 & $\mathrm{CA}$ & Castle Wind & $\begin{array}{l}\text { Unsolicited Project } \\
\text { Application }\end{array}$ & - & 0 & 1,000 & 1,000 & $\mathrm{~N} / \mathrm{A}$ & 334 & TBD & $\begin{array}{c}\text { Trident } \\
\text { Winds/EnBW }\end{array}$ \\
\hline 35 & $\mathrm{CA}$ & Humboldt & BOEM Call Area & - & - & - & - & - & - & - & - \\
\hline 36 & $\mathrm{CA}$ & Redwood Energy & $\begin{array}{l}\text { Unsolicited Project } \\
\text { Application }\end{array}$ & - & 0 & 150 & 150 & N/A & 50 & TBD & EDPR/PPI \\
\hline 37 & $\mathrm{HI}$ & Oahu South & BOEM Call Area & & - & - & - & - & - & - & - \\
\hline 38 & $\mathrm{HI}$ & AWH Oahu South & $\begin{array}{l}\text { Unsolicited Project } \\
\text { Application }\end{array}$ & - & 0 & 400 & 400 & N/A & 133 & TBD & AW Wind \\
\hline 39 & $\mathrm{HI}$ & Progression & $\begin{array}{l}\text { Unsolicited Project } \\
\text { Application }\end{array}$ & - & 0 & 400 & 400 & N/A & 133 & TBD & Progression Wind \\
\hline 40 & $\mathrm{HI}$ & Oahu North & BOEM Call Area & - & - & - & - & - & - & - & - \\
\hline 41 & $\mathrm{HI}$ & AWH Oahu North & $\begin{array}{l}\text { Unsolicited Project } \\
\text { Application }\end{array}$ & - & 0 & 400 & 400 & N/A & 133 & TBD & AW Wind \\
\hline \multicolumn{5}{|c|}{ Total } & $2,073 \mathrm{MW}$ & 23,751 MW & $25,824 \mathrm{MW}$ & & & & \\
\hline \multicolumn{12}{|c|}{$\begin{array}{l}\text { 1. Location refers to physical location of the project. The offtake column identifies where the project sells its power and other attributes. } \\
\text { 2. Some project names may change based on successful bids to state procurement solicitations } \\
\text { 3. Future commence operation dates are subject successfully negotiating offtake agreement and may change } \\
\text { 4. Announced capacity describes the size of a project as stipulated by a developer to regulators } \\
\text { 5. Lease Area Potential describes the potential capacity that could be installed in a lease area using a } 3 \mathrm{MW} / \mathrm{km}^{2} \text { density } \\
\text { 6. Pipeline capacity represents the lease area potential minus any developer announced capacity } \\
\text { 7. Sizes for Unsolicited Project Applications are likely to change during stakeholder and regulatory review processes and may be eliminated in the future } \\
\text { 8. Lease areas can often accommodate multiple projects or project phases built incrementally. The "+ Residual" refers to remaining space in the lease area that } \\
\text { may be utilized in the future } \\
\text { 9. The two Wind Energy Areas in North Carolina have currently not been leased by BOEM }\end{array}$} \\
\hline
\end{tabular}




\subsubsection{U.S. Offshore Wind Market Forecasts to 2030}

Figure 7 is a compilation of three independent industry forecasts for offshore wind deployment in the United States for the period extending to the year 2030. These estimates were developed by BNEF (2018b), 4C Offshore (2018), and University of Delaware's SIOW (2019) ${ }^{18}$ respectively. Combined, they illustrate the degree of expected market growth and the possible variability associated with the year, size, and location of future projects.

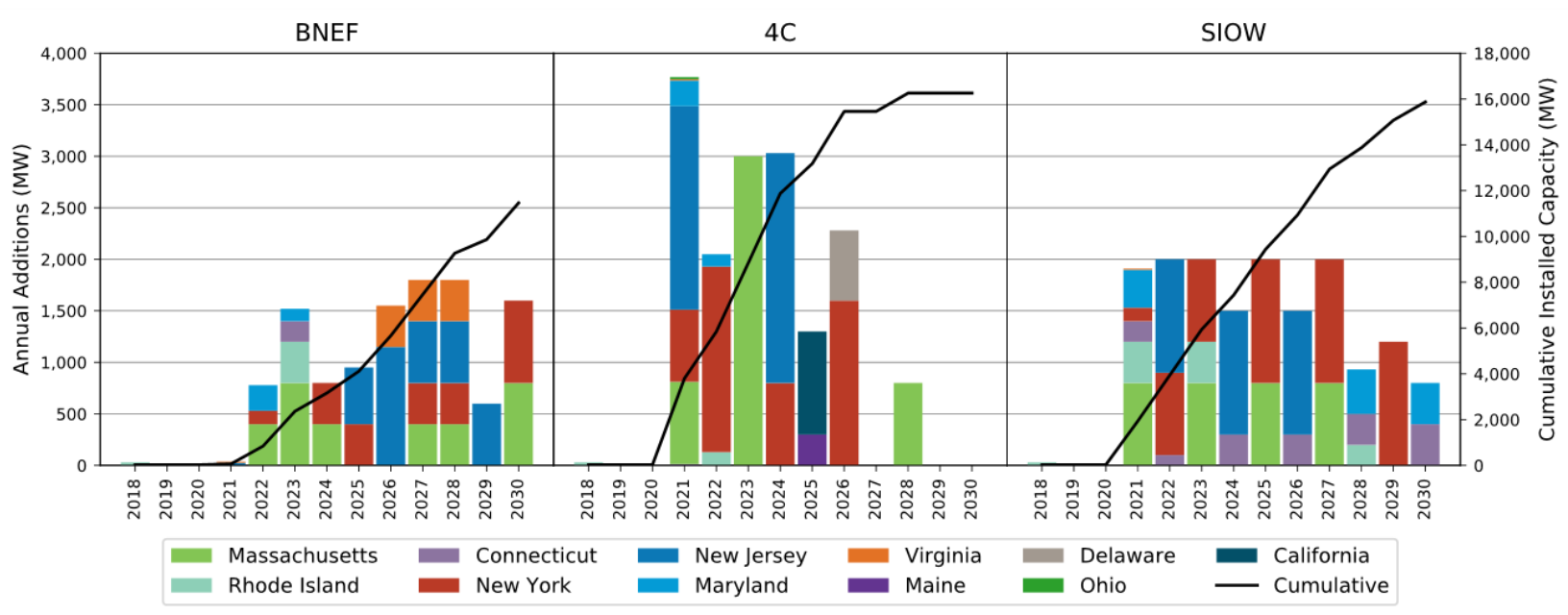

Figure 7. U.S offshore wind market forecasts (annual additions-left axis) (cumulative capacity through 2030-right axis)

The forecasts estimate that the U.S. offshore wind market will cumulatively deploy between 4 and 13 GW by 2025, and 11 and $16 \mathrm{GW}$ by 2030. All three forecasts agree that the U.S. market has the potential to be greater than $10 \mathrm{GW}$ by 2030 , but the size and speed of build-out are likely to be impacted by regulatory uncertainty, availability of installation vessels and port infrastructure, land-based grid planning and upgrades, and evolving market demand. All forecasts predict the majority of future offshore wind deployment out to 2030 will occur on the East Coast in states with currently existing or planned offshore wind procurement goals. Only $4 \mathrm{C}$ Offshore's forecast includes commercial-scale floating projects by 2030: one on the West Coast off California, and one off the state of Maine.

The main factor causing variability in the forecasts is uncertainty regarding state policy as well as the size and regularity of future procurements beyond state-level solicitations that have already been announced. Other significant factors include potential problems acquiring project financing, vessel availability, cost reduction challenges, problems with environmental and geotechnical surveys, and unexpected issues with competing ocean uses. The forecasts likely assume the creation of new offshore wind lease areas to fully support state procurement targets, but this is not stated explicitly. For example, New York's 9-GW-by-2035 target may necessitate obtaining capacity from neighboring WEAs in states like Rhode Island, Massachusetts, and New Jersey, and establishing new lease areas. As such, there has been much speculation over the four Call Areas in the New York Bight but at this time it is not known if or when BOEM will propose new WEAs (BOEM 2019b).

\footnotetext{
${ }^{18}$ Please note University of Delaware's Special Initiative for Offshore Wind forecast is based on the expected date a state selects to procure offshore wind capacity. A 3-year time lag is assumed from the time the procurement occurs until the project becomes fully operational.
} 


\subsection{Regulatory Activity}

\subsubsection{Lease Activity}

Acquiring exclusive rights to develop a lease area in federal waters (where most lease areas are located) is the first fundamental step toward building an offshore wind project in the United States.

Market consolidation was a major trend in 2018, driven by international developers purchasing the assets of smaller U.S. companies. Although construction for commercial projects has not yet begun in earnest, approximately $\$ 1.39$ billion was exchanged in the United States this year in gross revenue involving lease areas and corporate acquisitions:

- In April 2018, Ørsted asked BOEM to reassign $107 \mathrm{~km}^{2}$ in the southern portion of lease area OCS-A 0482 (Garden State Ocean Energy) in Delaware to the Skipjack project. Skipjack now has its own lease area: OCS-A 0519.

- In December 2018, Atlantic Shores Offshore Wind, a partnership between Électricité de France Renouvelables (EDF) and Shell New Energies, bought lease area OCS-A 0499 from US Wind for \$215 million pending regulatory approval (offshoreWIND.biz 2018a).

- In November 2018, Ørsted completed the acquisition of Deepwater Wind's offshore assets including their lease areas for a reported $\$ 510$ million (Ørsted 2018).

- In February 2019, Ørsted sold a partial ownership stake for \$225 million in some of their newly acquired Deepwater projects to Eversource Energy, a utility serving Connecticut, Rhode Island, and Massachusetts (Eversource Energy 2019).

Another major market trend in 2018 was an increase in offshore lease area prices, as demonstrated in BOEM's sale of three offshore wind lease areas in the Massachusetts WEA. Each lease area sold for at least \$135 million. The lease areas had previously been up for auction in January 2015 but did not receive any bids. The results of this auction are shown in Table 4.

Table 4. BOEM's Massachusetts Offshore Wind Auction Results from December 2018

\begin{tabular}{|c|c|c|c|c|c|c|}
\hline State & Lease Area & $\begin{array}{c}\text { Auction } \\
\text { Date }\end{array}$ & $\begin{array}{c}\text { Provisional } \\
\text { Winner }\end{array}$ & Winning Bid & $\begin{array}{c}\text { Size } \\
\mathbf{( k m}^{\mathbf{2}} \mathbf{)}\end{array}$ & Lease Area Potential \\
\hline MA & OCS-A 0520 & $12 / 14 / 18$ & Equinor & $\$ 135,000,000$ & 521 & $1,564 \mathrm{MW}$ \\
\hline MA & OCS-A 0521 & $12 / 14 / 18$ & $\begin{array}{c}\text { Mayflower Wind } \\
\text { Energy }\end{array}$ & $\$ 135,000,000$ & 516 & $1,547 \mathrm{MW}$ \\
\hline MA & OCS-A 0522 & $12 / 14 / 18$ & Vineyard Wind & $\$ 135,100,000$ & 536 & $1,607 \mathrm{MW}$ \\
\hline
\end{tabular}

In aggregate, the three lease areas in Massachusetts have the potential to support at least $4.7 \mathrm{GW}$ of new capacity. Figure 8 shows the overall trend of increasing lease sale prices in the United States since 2013, on the basis of $\$ / \mathrm{km}^{2}$. 


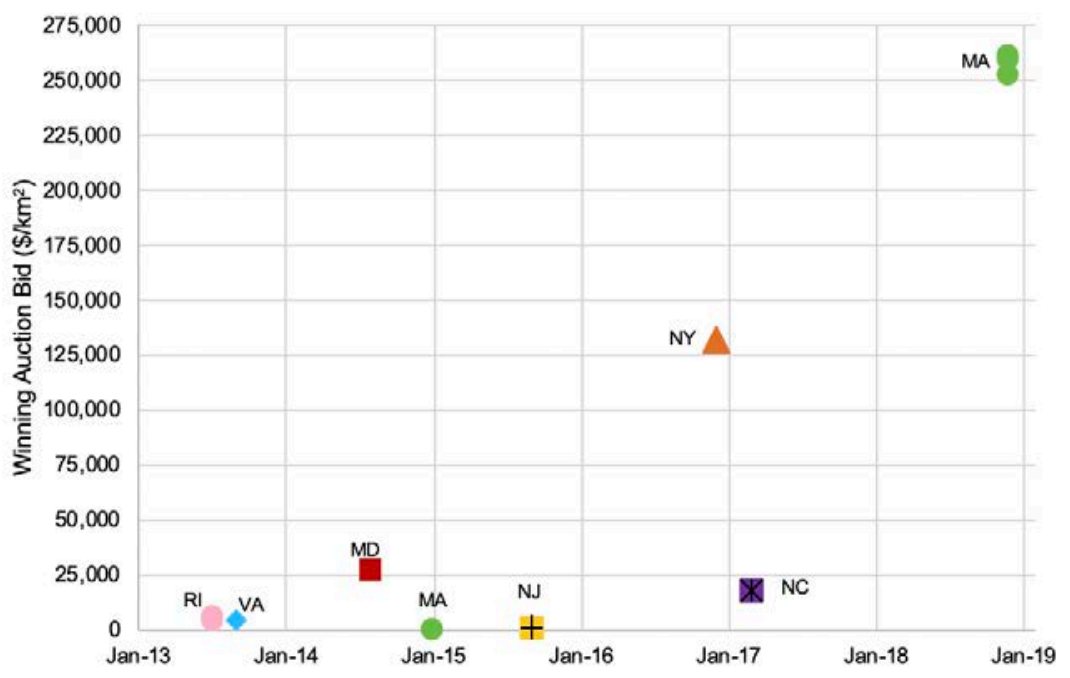

Figure 8. U.S. offshore wind lease sale prices to date by year

Notably, the winning auction bid price of $\$ 135$ million surpassed the previous record-winning sale price of \$42.4 million in Equinor's 2016 acquisition of the New York lease area. Not surprisingly, the highest-priced leases were in states with both proposed and implemented offshore wind offtake policies (e.g., Massachusetts, New York, Maryland, and Massachusetts) in 2018.

Although increased lease sale prices may be a signal that the offshore wind market is maturing and the bankability of future projects is increasing, it may also offset some expected (or required ${ }^{19}$ ) project price reductions and could increase the delivery price of a project's electricity. As an example, NREL calculated that recent Massachusetts lease sale prices could increase the levelized cost of energy (LCOE) for a hypothetical $800-\mathrm{MW}$ project by about 5\% relative to U.S. projects that acquired lease areas prior to 2016.

\subsubsection{New Area Identification}

BOEM periodically publishes Calls for Information and Nominations to assess commercial competitive interest for offshore wind development on specific parcels of ocean acreage in federal waters. The information gathered during these calls is used by BOEM in conjunction with other stakeholder input to identify future WEAs and subsequent lease area auctions. A Call Area is a precursor to a defined wind energy area, but not all Call Areas become wind energy areas, and they are typically modified (reduced in size) to address stakeholder input. In 2015, BOEM issued calls for four areas in federal waters off South Carolina and in 2016 issued calls for two areas off the Hawaiian island of Oahu (BOEM 2019d). There are currently 13 Call Areas for offshore wind today in the United States. Table 5 lists the seven newest Call Areas created by BOEM in 2018, including four in New York and three in California. These can also be found on the maps in Figures 4 and 5, and in Table 3 (BOEM 2019b, 2019c).

\footnotetext{
${ }^{19}$ Some states, such as Massachusetts, have procurement policies that mandate that project prices in future solicitations must be lower than previous project prices to require a downward cost trend.
} 
Table 5. 2018 BOEM Offshore Wind Call Areas

\begin{tabular}{|c|c|c|}
\hline State & Name & Call Period \\
\hline NY & Fairways North Call Area & $4 / 11 / 2018-7 / 30 / 2018$ \\
\hline NY & Fairways South Call Area & $4 / 11 / 2018-7 / 30 / 2018$ \\
\hline NY/NJ & Hudson North Call Area & $4 / 11 / 2018-7 / 30 / 2018$ \\
\hline NY/NJ & Hudson South Call Area & $4 / 11 / 2018-7 / 30 / 2018$ \\
\hline CA & Humboldt Call Area & $10 / 19 / 2018-1 / 28 / 2019$ \\
\hline CA & Morro Bay Call Area & $10 / 19 / 2018-1 / 28 / 2019$ \\
\hline CA & Diablo Canyon Call Area & $10 / 19 / 2018-1 / 28 / 2019$ \\
\hline
\end{tabular}

\subsubsection{Stakeholder Engagement}

The offshore wind industry in the United States continues to look for strategies to responsibly develop projects that minimize interference with the environment as well as the following preexisting ocean uses:

- Fishing. In cooperation with the Rhode Island Coastal Resources Management Council and local fishermen, Avangrid-Copenhagen Infrastructure Partners (CIP) established a \$12.5-million trust fund to compensate fishermen who may be negatively impacted ${ }^{20}$ by Vineyard Wind's construction (Rhode Island Coastal Resources Management Council 2019). The Responsible Offshore Science Alliance has partnered with fishermen, the National Oceanic and Atmospheric Administration (NOAA), Equinor, EDF, Shell, and Ørsted to disseminate salient and credible fisheries data (Froese 2019a). Ørsted partnered with the Responsible Offshore Development Alliance to improve communication between fishermen and their project planners (Saltzberg and Dowd 2019). Equinor and EDF also joined the alliance's Joint-Industry Task Force to ensure fishing and offshore wind development can coexist (Froese 2019b). The Responsible Offshore Development Alliance has also partnered with BOEM, NOAA, the U.S. Coast Guard, and other fishing industry liaisons to ensure that stakeholder concerns and best mitigation practices are incorporated into regulatory review processes. The group conducted multiple workshops in 2019 to minimize potential impacts of offshore wind development on fishermen.

- Environmental. Offshore wind construction and operations could potentially impact marine mammals, ${ }^{21}$ fisheries, or avian species. Of specific interest in the northeast is the North Atlantic right whale, one of the world's most endangered marine mammals with historical migration routes that transit multiple offshore WEAs. In April 2018, Bay State Wind announced it would provide \$2 million in research grants to help protect New England marine mammals (Bay State Wind 2018). In 2019, Equinor partnered with the Conservation Society and Woods Hole Oceanographic Institute to deploy acoustic buoys to better understand whale activities near proposed construction areas (Lillian 2019). Vineyard Wind signed an agreement with the National Wildlife Federation, Natural Resources Defense Council, and Conservation Law Fund to develop a construction strategy that minimizes pile driving and geophysical surveys during North Atlantic right whale migration periods, sets vessel speed limits to minimize marine mammal collision, and adopts new technologies like bubble screens to minimize installation noise (Skopljak 2019a). Vineyard Wind is also accepting proposals from universities and private companies for new passive acoustic monitoring systems to detect when whales are in the vicinity and appropriately pause construction activities to mitigate negative impacts (Skopljak 2019b). LEEDCo continues to work through federal and state regulations to minimize the impact of offshore wind energy on bird and bat species. As a resource for the public, DOE's Tethys database ${ }^{22}$ provides users with access to scientific studies that can help developers, regulatory staff, stakeholders, and researchers effectively site renewable

\footnotetext{
${ }^{20}$ Offshore wind construction may impact the availability of certain fish species or interfere with the ability of fishermen to fish in certain locations.

${ }^{21}$ Underwater noise associated with offshore wind construction (especially pile driving) may impact marine mammal communication and migration.

${ }^{22}$ Please visit DOE's Tethys database at https://tethys.pnnl.gov/.
} 
projects and employ installation and operations techniques that minimize impact to the environment (DOE 2018). Additional public resources relevant to offshore wind include BOEM's Environmental Science Database (BOEM 2019e), the Northeast Regional Ocean Council Data Portal (NOAA 2019a), and the Mid-Atlantic Ocean Data Portal (NOAA 2019b).

- Navigation. To avoid collisions and entanglement of fishing gear, Vineyard Wind proposed maritime transit corridors through their lease area with the support of BOEM, local stakeholders, and the U.S. Coast Guard (Vineyard Wind 2018d).

- Military. As reported in the 2017 Offshore Wind Technologies Market Update, offshore wind developers, state agencies, the U.S. Department of Defense, and BOEM have been working together to resolve potential offshore wind conflicts with military operations, training, and radar. Areas with military activities and potential offshore wind development include California, Hawaii, New York, Delaware, Maryland, North Carolina, and South Carolina. These discussions are continued in 2018 and are likely to remain active in the foreseeable future.

\subsection{U.S. Offshore Wind Project Offtake and Policy Assessment}

\subsubsection{Project Offtake Agreements}

In addition to obtaining site control and regulatory approval, negotiating an offtake agreement to sell the electricity and other possible clean power attributes (e.g., offshore renewable energy credits [ORECs]) is one of the three crucial steps to developing a bankable project. In the United States, each state has unique procurement targets and uses different mechanisms to negotiate the duration and terms of buying an individual project's electrical generation from a developer. ${ }^{23}$ Eight offtake agreements have been signed for seven U.S. projects and two projects are in the process of negotiating terms with electric distribution companies, as shown in Table 6. (Note that Revolution is one project but is selling power to two different states.)

\footnotetext{
${ }^{23}$ As shown in Table 6, some of the most common offtake agreement types are PPAs; legal contracts where a developer sells a project's power and other attributes to a buyer for a specified price and term; offshore renewable energy credits, in which each credit represents 1 MWh of energy and other attributes generated from an offshore wind energy project; and utility owned, wherein an offshore wind project is fully owned by a utility and sells power directly to utility customers.
} 
Table 6. U.S. Offshore Wind Offtake Agreements as of June 10, 2019

\begin{tabular}{|c|c|c|c|c|c|}
\hline Project & $\begin{array}{l}\text { Offtake } \\
\text { State }\end{array}$ & $\begin{array}{c}\text { Offtake } \\
\text { Mechanism }\end{array}$ & $\begin{array}{c}\text { Public Utility } \\
\text { Commission } \\
\text { Approved }\end{array}$ & $\begin{array}{l}\text { Offtake } \\
\text { Mechanism } \\
\text { Price }\end{array}$ & Description \\
\hline $\begin{array}{l}\text { Block Island } \\
\text { Wind Farm }\end{array}$ & $\mathrm{RI}$ & PPA & Yes & \$244/MWh & $\begin{array}{l}\text { In } 2014 \text {, Deepwater Wind signed a } 20 \text {-year PPA with } \\
\text { National Grid for } \$ 244 / \mathrm{MWh} \text {, with a } 2.5 \% \text { annual escalator. }\end{array}$ \\
\hline South Fork & NY & PPA & Yes & Undisclosed & $\begin{array}{l}\text { In 2017, Deepwater Wind signed a } 20 \text {-year PPA with Long } \\
\text { Island Power Authority for } 90 \mathrm{MW} \text { at an undisclosed price. In } \\
2019 \text {, Long Island Power Authority executed an amendment } \\
\text { in the PPA to increase the offtake agreement to } 130 \mathrm{MW} \text {. }\end{array}$ \\
\hline US Wind & MD & MD ORECs & Yes & \$131.92/MWh & $\begin{array}{l}\text { In } 2017 \text {, Maryland awarded US Wind ORECs }{ }^{24} \text { for } 248 \mathrm{MW} \\
\text { of capacity for } 20 \text { years. Each year, } 913,945 \text { ORECs will be } \\
\text { sold. The levelized OREC price is } \$ 131.94 / \mathrm{MWh} \text {. }\end{array}$ \\
\hline Skipjack ${ }^{25}$ & MD & MD ORECs & Yes & $\$ 131.92 / \mathrm{MWh}$ & $\begin{array}{l}\text { In } 2017 \text {, Maryland awarded Skipjack ORECs for } 120 \mathrm{MW} \text { of } \\
\text { capacity for } 20 \text { years. Each year, } 455,482 \text { ORECs will be } \\
\text { sold. The levelized OREC price is } \$ 131.94 / \mathrm{MWh} \text {. }\end{array}$ \\
\hline $\begin{array}{l}\text { Vineyard } \\
\text { Wind }\end{array}$ & MA & PPA & Yes & $\begin{array}{l}\text { \$74/MWh } \\
\$ 65 / \mathrm{MWh}\end{array}$ & $\begin{array}{l}\text { In } 2018 \text {, Vineyard Wind signed two } 400-M W \text { PPAs with } \\
\text { Massachusetts utilities for } 20 \text { years. The levelized first-year } \\
\text { prices of the PPAs were } \$ 74 / \mathrm{MWh}(2022 \$) \text { and } \$ 65 / \mathrm{MWh} \\
(2023 \$) \text {, respectively. }\end{array}$ \\
\hline $\begin{array}{l}\text { Coastal } \\
\text { Virginia } \\
\text { Offshore } \\
\text { Wind }\end{array}$ & VA & $\begin{array}{l}\text { Utility } \\
\text { Owned }\end{array}$ & Yes & $\$ 780 / \mathrm{MWh}^{26}$ & $\begin{array}{l}\text { In } 2018 \text {, Virginia regulators approved Dominion/Ørsted to } \\
\text { construct a } 12-\mathrm{MW} \text { demo project. The estimated levelized } \\
\text { cost of energy is } \$ 780 / \mathrm{MWh} \text {. }\end{array}$ \\
\hline $\begin{array}{l}\text { Revolution } \\
\text { Wind }\end{array}$ & CT & PPA & Yes & \$94/MWh & $\begin{array}{l}\text { In } 2018 \text {, Ørsted signed a } 20 \text {-year PPA with Eversource and } \\
\text { United Illuminating for } 200 \mathrm{MW} \text {, with a levelized PPA price of } \\
\text { approximately } \$ 94 / \mathrm{MWh} \text {. Ørsted has been approved to start } \\
\text { negotiations on an additional } 100 \mathrm{MW} \text {. }\end{array}$ \\
\hline $\begin{array}{l}\text { Revolution } \\
\text { Wind }\end{array}$ & RI & PPA & Yes & $\$ 98.43 / \mathrm{MWh}$ & $\begin{array}{l}\text { In } 2019, \varnothing \text { rsted signed a } 20 \text {-year PPA with National Grid for } \\
400 \mathrm{MW} \text {. The proposal was approved by the Public Utility } \\
\text { Commission, and the all-in price is } \$ 98.43 / \mathrm{MWh} \text {. }\end{array}$ \\
\hline Icebreaker & $\mathrm{OH}$ & PPA & Pending & TBD & $\begin{array}{l}\text { LEEDCo is working to secure offtake with multiple partners } \\
\text { for the project's electricity. }\end{array}$ \\
\hline Aqua Ventus & ME & PPA & Pending & TBD & Aqua Ventus I is negotiating a PPA with Central Maine Power. \\
\hline
\end{tabular}

\subsubsection{State Policies}

The U.S. offshore wind market continues to be driven by an increasing amount of state-level offshore wind procurement activities and statutory policies. In aggregate, these activities now call for the deployment of 19,968 MW of offshore wind capacity by 2035 , almost four times the aggregate state-level targets identified at the end of 2017. These commitments are shown in Table 7.

Note that the states that have adopted offshore wind energy policies listed in Table 7 may not have their own offshore wind resources. For several projects (e.g., Revolution, Skipjack, South Fork), deployment is being planned in a WEA adjacent to the state ${ }^{27}$ that will receive the power, generally at a location where the most favorable PPAs can be negotiated. The primary requirement is that the project is close enough to the onshore injection point to avoid prohibitive costs for the export cables.

\footnotetext{
${ }^{24}$ Each OREC represents $1 \mathrm{MWh}$ of offshore wind generation and is a remuneration mechanism for the environmental attributes of offshore wind generation.

${ }^{25}$ Note that Skipjack is both a lease area and a project.

${ }^{26}$ Please note the levelized price for Coastal Virginia Offshore Wind is significantly higher than other projects because it is a demonstration project and is unable to leverage economies of scale.

${ }^{27}$ For example, the Phase 1 New York offshore wind solicitation allows generators to interconnect with other markets (PJM Interconnection or ISO New England), as long as the power can be sold into the New York control area.
} 
Table 7. Current U.S. Offshore Wind State Policies and Activity as of June 10, 2019

\begin{tabular}{|c|c|c|c|c|c|c|c|c|}
\hline State & $\begin{array}{c}2018 \text { Capacity } \\
\text { Commitment }^{28} \\
\text { (MW) }\end{array}$ & $\begin{array}{l}\text { Offshore } \\
\text { Wind } \\
\text { Solicited } \\
\text { (MW) }\end{array}$ & $\begin{array}{l}\text { Contract } \\
\text { Type }\end{array}$ & $\begin{array}{l}\text { Target } \\
\text { Year }\end{array}$ & Statutory Authority & $\begin{array}{c}\text { Year } \\
\text { Enacted }\end{array}$ & $\begin{array}{l}\text { RPS } \\
\text { Goal }^{29}\end{array}$ & $\begin{array}{l}\text { State } \\
\text { RPS } \\
\text { Year }\end{array}$ \\
\hline \multirow{2}{*}{ MA } & 1,600 & 1600 & PPA & 2027 & $\begin{array}{c}\text { An Act to Promote Energy } \\
\text { Diversity }(\mathrm{H} .4568)\end{array}$ & 2016 & \multirow{2}{*}{$35 \%$} & \multirow{2}{*}{2030} \\
\hline & $1,600^{30}$ & - & PPA & 2035 & $\begin{array}{l}\text { An Act to Advance Clean } \\
\text { Energy }(\mathrm{H} .4857)\end{array}$ & 2018 & & \\
\hline $\mathbf{R I}^{31}$ & 400 & 400 & PPA & - & - & - & $31 \%$ & 2030 \\
\hline NJ & 3,500 & 1,100 & OREC & 2030 & $\begin{array}{l}\text { Executive Order } 8 \\
\qquad \text { AB No. } 3723\end{array}$ & 2018 & $50 \%$ & 2030 \\
\hline \multirow{4}{*}{ MD } & $368^{32}$ & 368 & OREC & 2030 & $\begin{array}{c}\text { Maryland Offshore Wind } \\
\text { Energy Act }\end{array}$ & 2013 & \multirow{4}{*}{$24 \%$} & \multirow{4}{*}{2020} \\
\hline & 400 & - & \multirow{3}{*}{ OREC } & 2026 & \multirow{3}{*}{ Senate Bill $516^{33}$} & \multirow{3}{*}{2019} & & \\
\hline & 400 & - & & 2028 & & & & \\
\hline & 400 & - & & 2030 & & & & \\
\hline \multirow[t]{2}{*}{ NY } & 2,400 & $930^{34}$ & OREC & 2030 & $\begin{array}{l}\text { Case 18-E-0071 Order } \\
\text { Establishing Offshore Wind } \\
\text { Standard and Framework } \\
\text { for Phase } 1 \text { Procurement }\end{array}$ & 2018 & \multirow[t]{2}{*}{$50 \%$} & \multirow[t]{2}{*}{2030} \\
\hline & 6,600 & - & TBD & 2035 & $\begin{array}{l}\text { Climate Leadership and } \\
\text { Community Protection Act }\end{array}$ & 2019 & & \\
\hline \multirow[t]{2}{*}{ CT } & $300^{35}$ & 300 & PPA & 2020 & $\begin{array}{c}\text { House Bill } 7036 \text { (Public Act } \\
17-144)\end{array}$ & 2017 & \multirow[t]{2}{*}{$44 \%$} & \multirow[t]{2}{*}{2030} \\
\hline & 2,000 & - & TBD & 2030 & House Bill $7156^{36}$ & 2019 & & \\
\hline VA & - & 12 & $\begin{array}{l}\text { Utility } \\
\text { Owned }\end{array}$ & 2028 & Virginia Energy Plan & TBD & - & - \\
\hline TOTAL & $19,968 \mathrm{MW}$ & $4,710 \mathrm{MW}$ & & & & & & \\
\hline
\end{tabular}

${ }^{28}$ State commitments in this table are listed incrementally and are additive (e.g., New York has a 9,000 MW goal by 2035).

${ }^{29}$ RPS goals are often staged over time; for this table, only the nearest-term RPS goal is included for simplification purposes.

${ }^{30}$ H.4857 authorized Massachusetts Department of Energy Resources to consider an additional 1,600 MW procurement by 2035. On May 31, 2019, the

Department of Energy Resources said it would use the authorization and hold 800-MW solicitations in 2022 and 2024, and in 2026, if needed.

${ }^{31}$ Rhode Island has a strategic goal to increase the state's clean energy to $1,000 \mathrm{MW}$ by 2030 . However, the state has no offshore-wind-specific statutory requirement or goal.

32 The Maryland Offshore Wind Energy Act of 2013 limits an offshore wind RPS carve-out to 2.5\% of total retail electric sales in state. This proportional goal corresponds to the OREC award on May 11, 2017, for $368 \mathrm{MW}$ awarded to Skipjack Offshore Energy (120 MW) and US Wind (248 MW). (Total retail electric sales in Maryland were 59,303,885 MWh in 2017 [Energy Information Administration 2019]).

${ }^{33}$ Maryland legislature passed SB516 May 25, 2019. It mandates the procurement of 400 MW by 2026,800 MW by 2028 , and 1,200 MW by 2030 .

${ }^{34}$ Long Island Power Authority solicited 90 MW for the South Fork project in 2017. The project size was later increased to 130 MW. NYSERDA solicited $800 \mathrm{MW}$ in 2018.

${ }^{35}$ Public Act 17-144 limits authority to procure offshore wind to 3\% of Connecticut electric distribution companies' total electric, which corresponds to approximately $200 \mathrm{MW}$. The other $100 \mathrm{MW}$ come from technology-neutral auctions.

${ }^{36}$ CT House Bill 7156 was signed into law June 10, 2019. It requires Connecticut to procure 2,000 MW by 2030 and DOE and Environmental Protection to issue a solicitation by June 24, 2019. 
In April 2018, New Jersey increased its RPS goal to 50\% by 2030 and its offshore wind goal from 1,100 MW to 3,500 MW by 2030 (New Jersey State Legislature 2018). In August 2018, Massachusetts passed new legislation to increase its offshore wind procurement goal from 1,600 MW by 2027 to 3,200 $\mathrm{MW}^{37}$ by 2035 (Commonwealth of Massachusetts 2018). In October 2018, Virginia published a state energy plan that proposed an offshore wind target of 2,000 MW by 2028 (BVG Associates 2018a). ${ }^{38}$ In January 2019, New York's Governor Cuomo increased the state's offshore wind goal to 9,000 MW by 2035 (New York State 2019a), which was codified into law in the Climate Leadership and Community Protection Act in June 2019 (New York State 2019b). Maryland also passed legislation in April 2019 to mandate the deployment of an additional 1,200 MW of offshore wind by 2030 (Maryland General Assembly 2019). In June 2019, Connecticut passed new legislation to procure 2,000 MW of offshore wind capacity by 2030 (Connecticut General Assembly 2019).

To meet their committed procurement targets, multiple states issued solicitations for commercial projects in 2018, and executed significant planning around future solicitations including the following:

- In New York, NYSERDA issued a solicitation for approximately $800 \mathrm{MW}$ of capacity worth of ORECs. Bids were due February 19, 2019, and NYSERDA announced that Atlantic Shores Offshore Wind (EDF/Shell), Empire Wind (Equinor), Liberty Wind (Avangrid/CIP), and Sunrise Wind (Ørsted and Eversource) all responded to the solicitation. Winners are expected to be announced in spring 2019.

- New Jersey issued a solicitation for 1,100 MW of ORECs that was open from September 20 to December 28, 2018. Three developers responded to the solicitation: Board Walk Wind (Equinor), Atlantic Shores Offshore Wind (EDF/Shell), and Ocean Wind (Ørsted). The Board of Public Utilities (BPU) is expected to announce a winner by summer 2019.

- NYSERDA plans to have another 800-MW solicitation in 2019 (NYSERDA 2019).

- The New Jersey BPU also announced plans for two additional solicitations for 1,200 MW in 2020 and 2022 (New Jersey BPU 2019).

- Maryland's new offshore wind procurement legislation requires the state to procure $400 \mathrm{MW}$ by 2026 , 800 MW by 2028, and 1,200 MW by 2030 (Maryland General Assembly 2019).

- Massachusetts Department of Public Utilities issued its second offshore wind solicitation on May 27, 2019, to meet the state's 1,600-MW-by-2027 goal. The request for proposals asks developers to submit plans for designs between 400 and 800 MW (Massachusetts Department of Energy Resources 2019a). Bids are due by August 9, 2019.

- The Massachusetts Department of Energy Resources conducted an offshore wind study to investigate the necessity, benefits, and costs of requiring Massachusetts's electric distribution companies ${ }^{39}$ to conduct additional offshore wind generation solicitations of up to 1,600 MW. The agency found that the additional capacity was in the best interest of the state and announced it will hold additional solicitations for up to $800 \mathrm{MW}$ of offshore wind in 2022 and 2024, and if necessary to meet the 1,600 MW target, in 2026 (Massachusetts Department of Energy Resources 2019b).

\footnotetext{
${ }^{37}$ Note the additional 1,600 MW is at the discretion of the Massachusetts Department of Energy Resources, so the ultimate procurement target could change.

${ }^{38}$ The state energy plan recommends $2,000 \mathrm{MW}$ and is awaiting action from the governor.

${ }^{39}$ Electric distribution companies are regulated entities that purchase wholesale energy and sell it to retail customers.
} 


\subsection{U.S. Infrastructure Trends}

\subsubsection{Vessels and Logistics}

A lack of specialized, U.S.-flagged offshore wind installation vessels and limitations imposed by the Jones $\mathrm{Act}^{40}$ continues to be a potential bottleneck for the nascent U.S. offshore wind industry. As reported in past market reports, multiple marine engineering companies (e.g., Gusto MSC, Zentech, AK Suda) have drafted designs and conducted cost studies for U.S.-flagged installation vessels, but no offshore installers publicly announced construction of a new vessel in 2018. The only known vessel development in 2018-2019 was Ørsted entering into partnership with WindServe Marine to construct two crew transfer vessels - one in North Carolina and the other in Rhode Island - for use at the Coastal Virginia Offshore Wind and Revolution Wind projects (Foxwell 2019). The lack of specialized U.S.-flagged installation and support vessels will likely prompt initial commercial-scale projects to use foreign-flagged installations vessels and U.S.-flagged feeder barges.

\subsubsection{Ports and Harbors}

Although no investments have been made for U.S.-flagged offshore wind installation vessels, developers and state bodies have started to make investments in port infrastructure to make sure there are sufficient cranes and laydown space required for large-scale commercial projects. There are a number of ports in the United States that are potentially suitable for offshore wind construction, staging, and assembly. The few ports that have made recent infrastructure investments to upgrade and prepare for the first wave of projects are listed in Table 8. Going forward, this list is expected to grow.

Table 8. Ports with Recent Investments for the U.S. Offshore Wind Industry

\begin{tabular}{|c|c|c|c|}
\hline State & Location & Description & $\begin{array}{l}\text { Offshore Wind } \\
\text { Projects }\end{array}$ \\
\hline MA & $\begin{array}{l}\text { Port of New } \\
\text { Bedford }\end{array}$ & $\begin{array}{l}\text { Vineyard Wind is leasing the New Bedford Commerce Terminal for } \\
18 \text { months as the primary staging and deployment base for its } \\
800-\mathrm{MW} \text { project (Mass Live 2018). }\end{array}$ & Vineyard Wind \\
\hline MA & Brayton Point & $\begin{array}{l}\text { Anabaric and Commercial Development Company signed an } \\
\text { agreement to invest } \$ 650 \text { million into Brayton Point's Commerce } \\
\text { Center to create an offshore wind hub that has a } 1.2-G W \text { high- } \\
\text { voltage direct-current converter, } 400-\mathrm{MW} \text { battery storage, and } \\
\text { additional wind turbine component laydown space. }\end{array}$ & Multiple in MA and RI \\
\hline CT & New London & $\begin{array}{l}\text { Ørsted, the Connecticut Port Authority, and Gateway will invest } \\
\$ 93 \text { million in the State Pier at New London to expand the laydown } \\
\text { space, increase its heavy-lift capacity, and add other features } \\
\text { necessary for large-scale offshore wind development activities. } \\
\varnothing \text { rsted will lease rights to use the pier for } 10 \text { years. }\end{array}$ & Revolution Wind \\
\hline MD & $\begin{array}{l}\text { Tradepoint Atlantic } \\
\text { (Formerly Sparrow } \\
\text { Point) }\end{array}$ & $\begin{array}{l}\text { In 2017, US Wind and Deepwater Wind agreed to invest } \$ 115 \\
\text { million in new manufacturing and port infrastructure. }\end{array}$ & US Wind and Skipjack \\
\hline
\end{tabular}

The development and timing of port infrastructure could become a significant bottleneck for the industry. This may be especially true as wind turbines and project sizes continue to grow and put a strain on the capacity of existing infrastructure in terms of heavy lifting, ship access, clearances, channel draft, and physical laydown space. According to a recent McKinsey report, approximately five staging ports will be required to meet the needs for the first $10 \mathrm{GW}$ of offshore wind deployment on the Atlantic Coast alone (Lefevre-Marton et al. 2019).

\footnotetext{
${ }^{40}$ The Jones Act prohibits the maritime shipment of merchandise and passengers between two points in the United States by any vessel that is not U.S.flagged (domestically manufactured, owned, and operated). For offshore wind development, this means foreign-flagged turbine installation vessels are unable to carry turbine components from a U.S. port to a construction site in U.S. waters.
} 


\subsection{Other Regional Developments}

Most activity is centered on the WEAs and states that have specific offshore wind procurement activities. The activities highlighted here by region are notable yet were not documented earlier in this report.

\subsubsection{North Atlantic}

Other offshore wind activities for the North Atlantic region included the following:

- In February 2019, Maine's Governor Janet Mills signed an Executive Order to end a 2018 moratorium on the issuance of offshore wind permits in the state (Mills 2019). The University of Maine is now in the process of renegotiating the Aqua Ventus I PPA for its 12-MW floating demonstration project. If built, this project would likely be the first wind project using floating turbines in the United States.

- In January 2019, New Hampshire's Governor Christopher Sununu requested that BOEM establish an intergovernmental offshore renewable energy task force to coordinate renewable energy activities on the New Hampshire Outer Continental Shelf, including potential commercial leases for offshore wind (Sununu 2019).

- The New Jersey BPU denied EDF's application for 20 years of ORECs for its 24-MW Nautilus demonstration project (formerly known as Fishermen's Energy) (New Jersey BPU 2018). This ends a long process, which began in 2008, to build this offshore wind demonstration project approximately 2.8 miles off the coast of Atlantic City, New Jersey. Ultimately, the project failed because it was unable to demonstrate neteconomic benefits, as required under law by the Offshore Wind Economic Development Act.

\subsubsection{South Atlantic}

Offshore wind activities for the South Atlantic region included the following:

- In September 2018, BVG Associates and the Sierra Club published their Offshore Wind in Virginia: A Vision report. This study recommended that the state set a target to support $2 \mathrm{GW}$ of offshore wind development by 2028 and claimed this policy could create thousands of local jobs and make the state an offshore wind hub (BVG Associates 2018a). In 2018, The Virginia Advantage: The Roadmap for the Offshore Wind Supply Chain in Virginia assessed the state's port infrastructure and found that five ports could support offshore wind construction and manufacturing activities without significant upgrades (BVG Associates 2018b).

- In March 2019, North Carolina Governor Roy Cooper approved an offshore wind study to assess the state's ability to develop successful ports and manufacturing facilities (Durakovic 2019).

\subsubsection{Pacific}

Offshore wind activities for the Pacific region included the following:

- In 2018, California passed SB 100 (100 Percent Clean Energy Act), committing the state to realizing $100 \%$ of its total retail electricity sales from eligible renewable energy and zero-carbon resources by 2045. To comply with this mandate, California will consider the large-scale development of offshore wind. The state's offshore wind technical resource has been determined by NREL to be over $100 \mathrm{GW}$, and offshore wind deployment scenarios studied suggest that a potential build-out of several gigawatts may be feasible using floating technology. Floating technology is expected to be commercially available by the mid-2020s (Musial et al. 2016, 2017).

- On October 18, 2018, BOEM published a Call for Information and Nominations to gauge interest from prospective floating wind developers in commercial wind energy leases within three proposed areas off central and northern California (BOEM 2019c). The Call Areas are shown in Figure 5 on the central and northern California coasts. All together, these three Call Areas total approximately $2,784 \mathrm{~km}^{2}(687,823$ 
acres), which could potentially deliver a generating capacity of up to $8.4 \mathrm{GW}$. In response to the call, BOEM received 14 nominations from developers identifying their interest in developing certain portions of the Call Areas. Interested developers include Algonquin Power Fund, Wpd Offshore Alpha, Avangrid Renewables, Castle Wind/Energie Baden-Württemberg AG (EnBW), Cierco Corporation, EDF

Renewables, EDP Renewables North America, E.ON Development, Equinor Wind US, Mission Floating Wind, Northcoast Floating Wind, Northland Power America, Redwood Coast Energy Authority, and US Mainstream Renewable Power. 


\section{Overview of Global Offshore Wind Development}

\subsection{Global Offshore Wind Market}

Following the 2017 deployment of more than 3,500 MW, a record capacity of 5,652 MW new offshore wind was commissioned globally in 2018, as shown in Figure 9. The increase in global capacity can be attributed to a strong increase in deployment from the Chinese market, with 2,652 MW of new Chinese offshore wind capacity coming on line, followed by 2,120 MW commissioned in the United Kingdom, $835 \mathrm{MW}$ in Germany, 28 MW in Denmark, and about 17 MW divided between the rest of Europe and Vietnam. By the end of 2018, the global offshore wind installed capacity grew to 22,592 MW from 176 operating projects. Projections for 2019 indicate greater amounts of new global capacity based on projects currently under construction.

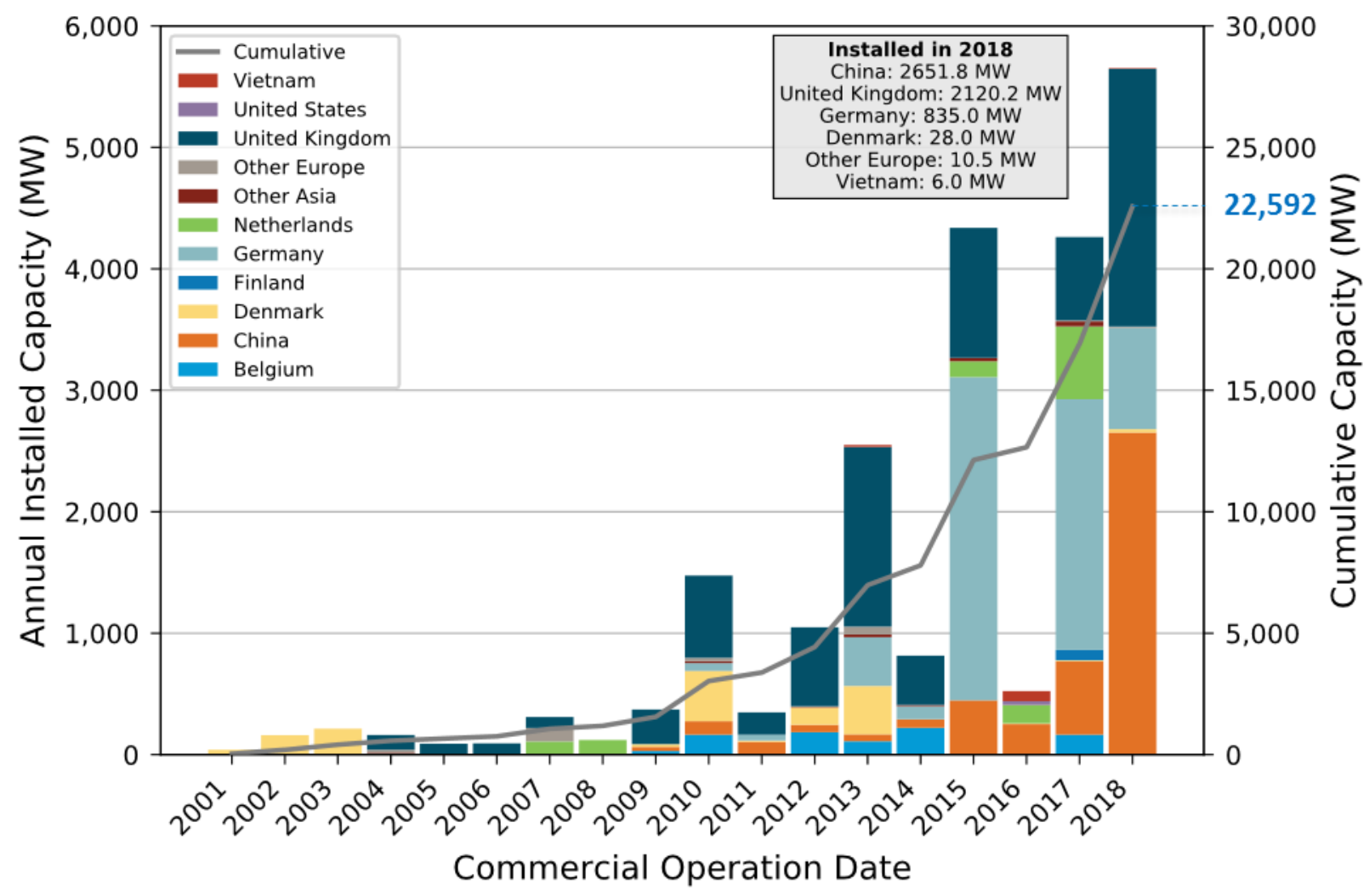

Figure 9. Global offshore wind in 2018 (annual installed capacity-left axis) (cumulative capacity-right axis)

The global offshore wind market is still centered in Europe, with approximately 17,979 MW of installed cumulative capacity. Asia is the second largest regional market, with 4,639 MW, and North America is the third largest market, with only $30 \mathrm{MW}$ of capacity installed today. The OWDB indicates that future market growth will shift toward the Asian and U.S. markets.

Europe's large regional offshore wind market is sustained in part because it has the most transparent national offshore wind procurement schedules, regionally based original equipment manufacturers (OEMs) and installers, mature logistical and manufacturing supply chains, and strong research and development networks to support its development. In addition, Europe has had 28 years of offshore wind experience. However, the Asian offshore wind market may soon surpass the European market in terms of annual capacity additions, driven primarily by China's demand for renewable energy and the motivation to advance the country's domestic manufacturing capabilities. This shift is noticeable in the 2018 annual capacity additions. As shown in Figure 10, there were three main countries contributing to offshore wind capacity in 2018 - China, the United Kingdom, and Germany. 


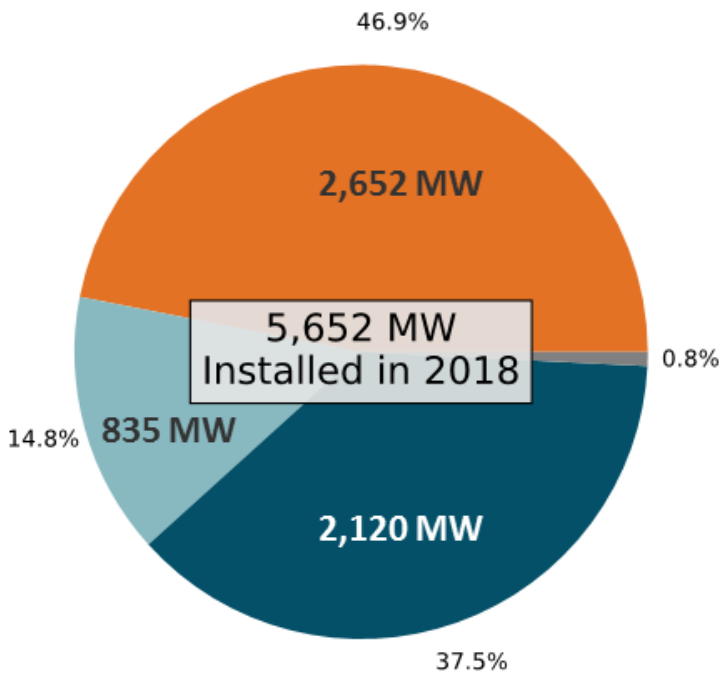

\section{China United Kingdom Other \\ Germany}

Figure 10. Installed offshore wind capacity by country in 2018

Of the 22,592 MW of cumulative offshore wind deployment recorded by the end of 2018, Figure 11 shows how that capacity is distributed among all countries. The United Kingdom continues to lead the world in terms of total deployment, with $35.2 \%$, followed by Germany (27.4\%), China (19.5\%), Denmark (6.4\%), the Netherlands (5\%), and Belgium (3.9\%).

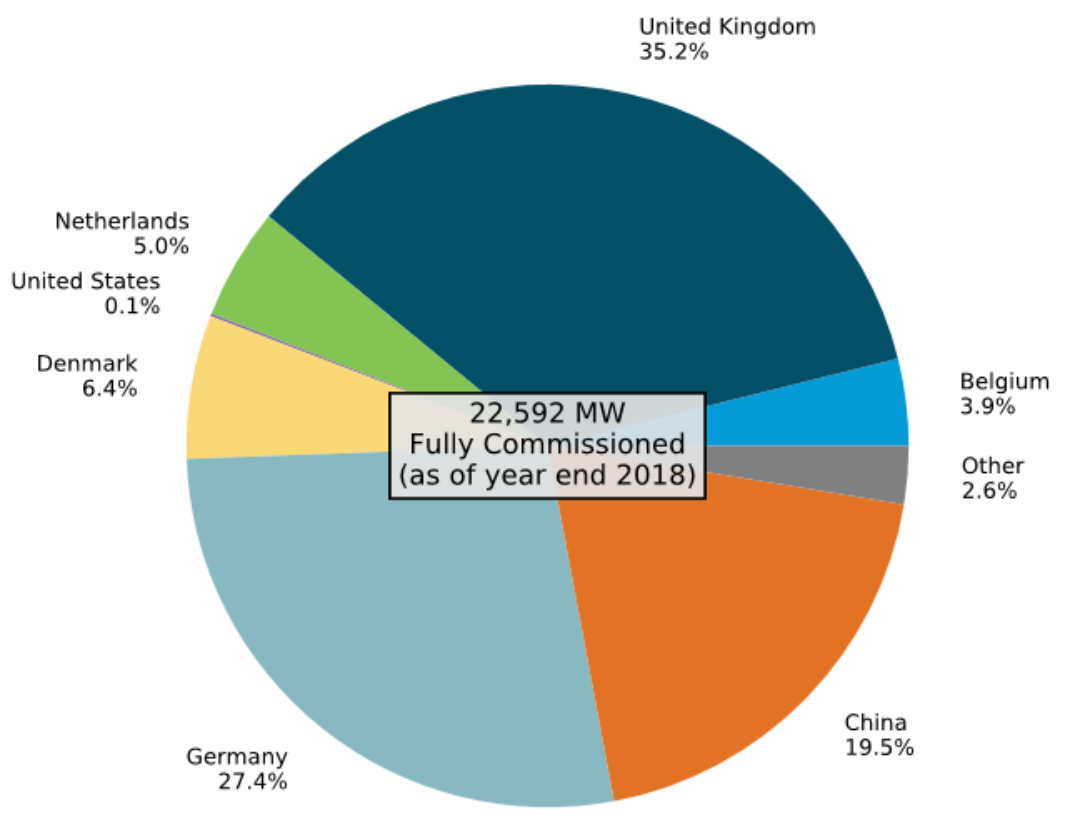

Figure 11. Cumulative offshore wind installed capacity by country 
Figure 12 shows the same data plotted in Figure 9 but provides more insight into how the cumulative capacity changed by country.

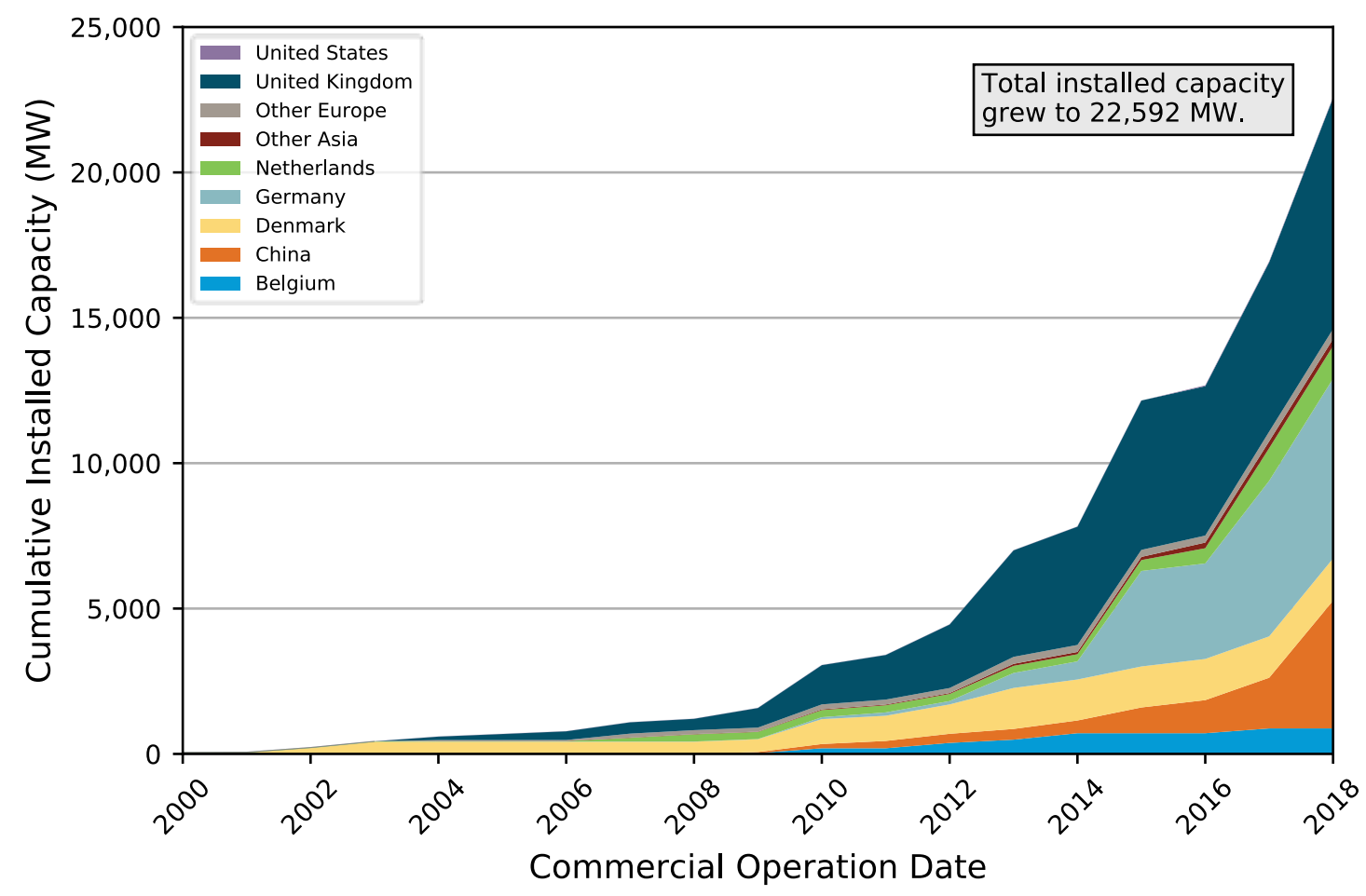

Figure 12. Cumulative installed offshore wind capacity by country over time

Historically, Denmark was clearly the first mover of the industry; however, being a small country, its longterm demand is smaller, and by 2010 the United Kingdom gained more total deployment. Germany began its transition to offshore wind around 2010 and has been increasing its deployment rapidly. Figure 12 also shows the sharp acceleration of the Chinese market, especially this past year-a trend that is likely to continue.

\subsubsection{European Market Activities}

As of December 31, 2018, 2,994 MW of additional offshore wind capacity was installed in Europe, bringing the total cumulative capacity to 17,979 MW. In 2018, Denmark installed $28 \mathrm{MW}$, France installed 2.2 MW, Germany installed 835 MW, Spain installed 5 MW, Sweden installed 3.3 MW, and the United Kingdom installed 2,120 MW. Table 9 provides a list of all the projects that reached commercial operation in 2018 by country. The table provides the project capacity values in megawatts and the name of the developer. Note that both of the French projects are subscale floating demonstration projects. 
Table 9. European Projects Installed and Grid Connected in 2018

\begin{tabular}{|c|c|c|c|}
\hline Country & Project Name & $\begin{array}{c}\text { Capacity } \\
\text { (MW) }\end{array}$ & Lead Developer \\
\hline Denmark & Nissum Bredning Vind & 28 & $\begin{array}{l}\text { Nissum Bredning } \\
\text { Vindmallelaug }\end{array}$ \\
\hline France & EOLINK 1/10 Scale Prototype & 0.2 & EOLINK \\
\hline France & Floatgen & 2 & Ideol \\
\hline Germany & Arkona & 385 & E.ON \\
\hline Germany & Borkum Riffgrund 2 & 450 & $\varnothing$ rsted \\
\hline Spain & Elisa/Elican Demonstration & 5 & Elican and ESTEYCO \\
\hline Sweden & Bockstigen & 3.3 & Momentum Gruppen A/S \\
\hline United Kingdom & Aberdeen Offshore Wind Farm & 93.2 & Vattenfall \\
\hline United Kingdom & $\begin{array}{l}\text { Blyth Offshore Demonstration } \\
\text { Array } 2\end{array}$ & 41.5 & EDF \\
\hline United Kingdom & Galloper & 353 & Innogy \\
\hline United Kingdom & Race Bank & 573.3 & $\varnothing$ rsted \\
\hline United Kingdom & Rampion & 400.2 & E.ON \\
\hline United Kingdom & Walney Extension & 659 & Ørsted \\
\hline
\end{tabular}

Looking beyond 2018, there has been a significant amount of additional offshore wind activity in Europe related to new policy, procurements, permits, and offtake agreements, indicating continued market growth. Some of the highlights of these activities by country include the following.

France. Although France initially implemented policies targeting $6 \mathrm{GW}$ of offshore wind by 2020 , disagreements over the feed-in tariff prices continually delayed commercial projects that had been approved in two tenders in 2012 and 2014. However, in June 2018, the French government finally approved the construction of six of the previously approved offshore wind projects after reducing the feed-in tariff. ${ }^{41}$ Each project is expected to receive between $150 € / \mathrm{MWh}$ and $200 € / \mathrm{MWh}$ (Reuters 2018). The projects, all expected to come on line around 2022, are Saint-Nazaire (480 MW), Courseulles-sur-Mer (496 MW), Fécamp (498 MW), Dieppe-Le Tréport (496 MW), and Ile d'Yeu et Noirmoutier (496 MW) (Espérandieu 2018).

Germany. In April 2018, six projects with CODs from 2022 to 2024 were awarded grid connection in the second German offshore wind tender. The projects were Baltic Eagle (476 MW), Gode Wind 4 (132 MW), Kaskasi (325 MW), Arcadis Ost (248 MW), Wikinger Sud (350 MW), and Borkum Riffgrund West I (420 MW). The German Renewable Source Act drives the German offshore wind market and has targeted installing $6.5 \mathrm{GW}$ by 2020 and $15 \mathrm{GW}$ of offshore wind capacity by 2030 . Because the German market is poised to achieve its offshore wind goals ahead of schedule, the German legislature initiated a grid reliability study to assess the feasibility of increasing the country's offshore wind goal to $20 \mathrm{GW}$ by 2030 (Foxwell 2018b).

\footnotetext{
${ }^{41} \mathrm{~A}$ feed-in tariff guarantees the amount of compensation a developer receives for every megawatt-hour of electricity that their project supplies to the grid.
} 
Poland. Poland held its first offshore wind tender in November 2018, awarding two projects the rights to connect to the grid. Additionally, the Polish Secretary of State announced the country was targeting $8 \mathrm{GW}$ of offshore wind deployment by 2030 (offshoreWIND.biz 2018b).

Portugal. Portugal continues to support the development of the 25-MW floating WindFloat Atlantic project. The project is expected to reach financial close and initiate construction in late 2019 pending government approval.

Spain. Spain deployed its first offshore wind project in the Canary Islands, the 5-MW Elisa/Elican, a novel gravity-base float-out system that can be fully assembled inshore, with a telescoping tower. According to $4 \mathrm{C}$ Offshore, the turbine became fully operational in March 2019. As such, this project will be counted toward the 2019 capacity additions (Skopljak 2019c).

United Kingdom. The United Kingdom continues to be the world leader in offshore wind, with over 7.9 GW of installed capacity. In November 2018, The Crown Estate announced the fourth round of offshore wind tenders would be held in May 2019 and subsequent tenders would occur every 2 years. Based on "market appetite," the tender was increased from 6 to $7 \mathrm{GW}$, and wind development regions that were limited to 50-m depths were extended to 60-m depths (The Crown Estate 2018).

\subsubsection{Asian Market Activities}

By the end of 2018, 2,658 MW of new offshore wind capacity was added in Asia, increasing the region's total cumulative installed capacity to 4,639 MW. In 2018, China added 2,652 MW and Vietnam added $6 \mathrm{MW}$.

Table 10 provides a list of all of the Asian projects that reached commercial operation in 2018 by country.

Table 10. Asian Projects Installed and Grid Connected in 2018

\begin{tabular}{|c|c|c|c|}
\hline Country & Project Name & $\begin{array}{c}\text { Capacity } \\
\text { (MW) }\end{array}$ & Developer \\
\hline China & Fuqing Xinghua Bay - Phase 1 & 77.4 & China Three Gorges New Energy Co. \\
\hline China & Guodian Zhoushan Putuo District 6 Zone 2 & 252 & GD Power Development Co. \\
\hline China & Jiang Su Ru Dong Jiangjiasha H2 & 300 & Shanghai Electric Power \\
\hline China & Jiangsu Longyuan Chiang Sand H1 & 300 & China Longyuan Power Group \\
\hline China & Jiangsu Luneng Dongtai & 200 & Shandong Luneng \\
\hline China & Laoting Bodhi Island Demonstration & 300 & Jointo Energy Investment \\
\hline China & Longyuan Jiangsu Dafeng (H12) & 200 & China Longyuan Power Group \\
\hline China & Longyuan Putian Nanri Island I & 200 & China Longyuan Power Group \\
\hline China & SPIC Binhai North H2 & 400 & State Power Investment Corporation \\
\hline China & SPIC Jiangsu Dafeng H3 & 302.4 & State Power Investment Corporation \\
\hline China & Zhuhai Guishan Hai Demonstration - Phase 1 & 120 & China Southern Power Grid \\
\hline Vietnam & Ben Tre 10 - Phase 1 & 6 & Mekong Wind Power \\
\hline
\end{tabular}

Looking beyond 2018, other significant offshore wind activities in Asia related to new policy, procurements, permits, and offtake agreements by country include the following.

China. China has a national offshore wind deployment goal of $5 \mathrm{GW}$ by 2020 ; however, the rapid increase in the number of proposed projects has been driven by the individual province-level goals in Jiangsu (3.5 GW), Fujian (2 GW), and Guangdong (2 GW) (Deign 2019). In May 2018, China's National Energy Administration determined that offshore wind power prices in 2019 and beyond will be set by competitive auctions instead of 
feed-in tariffs in an effort to increase competition and spur cost reductions in the industry (Recharge News 2018). These cost-reduction and province-level procurement targets, in conjunction with a rapidly maturing supply chain, are expected to dramatically accelerate the future deployment of offshore wind in China, potentially making it a world leader by 2030 (see Section 3.2).

Japan. In November 2018, the Japanese government passed a bill that created a national framework for offshore wind development. Under the law, the Japanese government will designate at least five offshore wind lease areas, hold competitive auctions, and award leases for 30-year terms. In January 2019, Tokyo Electric Power Company, Japan's largest utility, signed a memorandum of understanding with Ørsted to develop the Chosi project near Tokyo (Ørsted 2019). Although Japan still lacks firm government targets for offshore wind, outside analysts such as Wood Mackenzie predict that by 2028 the country will have $4 \mathrm{GW}$ of offshore wind (Hill 2019).

Taiwan. Taiwan has a national goal to develop $5.5 \mathrm{GW}$ of offshore wind capacity by 2025 (Jacobsen 2018). In April and June 2018 , the government awarded the first tranche of projects $(\sim 3.5 \mathrm{GW})$ the right to connect to the grid. In late 2018, the Taiwanese government proposed to reduce its feed-in-tariff before some of the awardees could finalize their power purchase agreements. This uncertainty led some developers to question the bankability of their projects and temporally suspend project development. Ultimately, the government settled on smaller feed-in-tariff reduction that enabled all projects to stay economically viable. In early 2019, Ørsted reached financial close on Changhua 1 (605 MW) and Changhua 2 (205 MW), Wpd reached financial close on Yunlin (640 MW), and Northland Power reached financial close on Hai Long 2A (300 MW) (4C Offshore 2019a).

South Korea. Although no projects were commissioned in South Korea in 2018, land-use constraints are shifting the focus for renewable energy to offshore wind power. In 2018, the government set a 12-GW offshore-wind-capacity-by-2030 target to help the country meet a $20 \%$ renewable energy target set earlier in 2017. In June 2018, the government adjusted the RPS to increase the renewable energy certificate (REC) value for offshore wind because of economic efficiency and ability to meet policy goals (Linklaters 2019). Offshore wind REC values are attractive because they increase with the distance from the interconnection facilities (Linklaters 2019).

\subsection{Offshore Wind Market Projections}

This report contains both near-term (2024) and medium-term (2030) projections for the global offshore wind market. Near-term trends are based on NREL's OWDB and medium-term trends are based on a collection of outside sources, but primarily BNEF and $4 \mathrm{C}$ Offshore. These projections can help illuminate broad market trends, identify different national and regional deployment trajectories, and approximate the level of uncertainty in future deployment estimates.

\subsubsection{Project Pipeline Through 2024}

The near-term project projection is based on data obtained for NREL's OWDB and represents our best understanding of the global offshore wind market. Note that market dynamics, policies, and future technological innovations are always subject to change, and could impact these projections.

Near-term projections are based on industry data reporting their status in the pipeline and the developers' expected commercial operation dates. Projects that have made it past financial close have a much higher probability of being completed and a much lower uncertainty about when they will be completed. Figure 13 shows that 9,511 MW of new offshore wind is underway globally, which is broken down by key countries. 


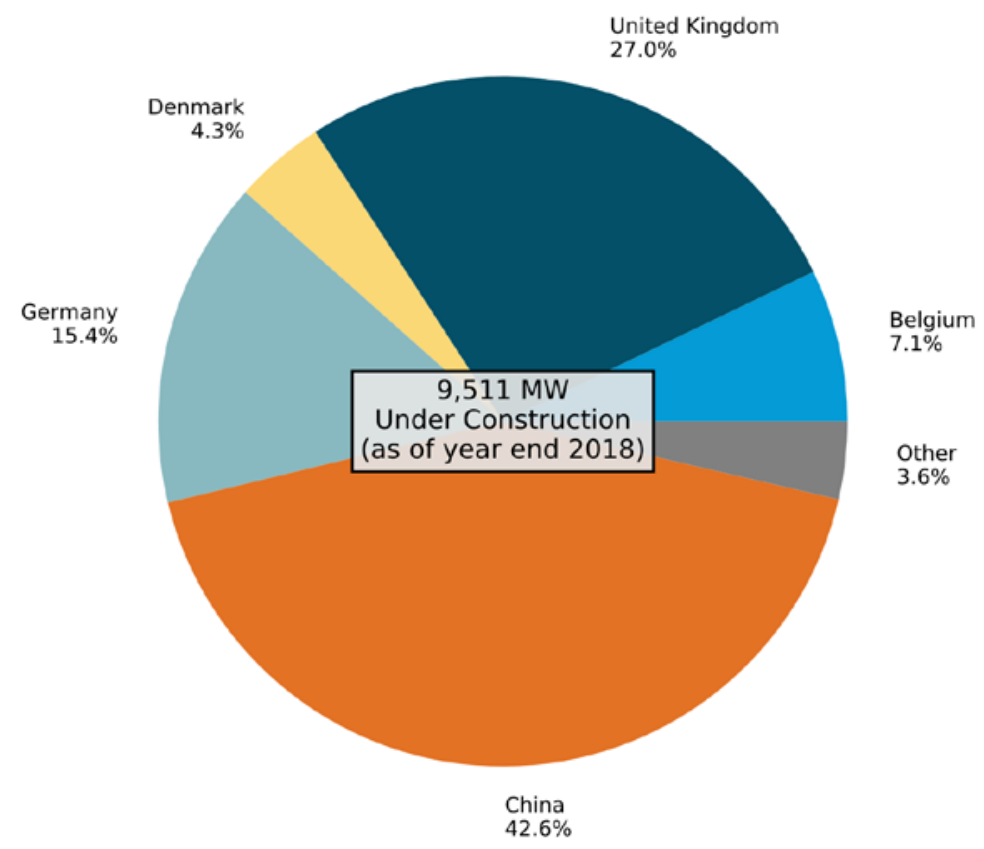

Figure 13. Offshore wind capacity under construction by country as of 2018

By the end of 2018, there were 12 European offshore wind projects under construction, representing 5,115 MW of new capacity to be commissioned. ${ }^{42}$ The majority of ongoing construction in Europe is occurring in the United Kingdom (2,520 MW) and Germany (1,460 MW), with smaller amounts in Belgium (678.6 MW) and Denmark (406 MW). In Asia, 17 projects, with a combined capacity of 3,469 MW, are currently under construction. Of the projects under construction, 12 are located in China, three in Vietnam, one in Japan, and one in South Korea. The increased amount of construction in Asia, especially China, represents a new market segment that is expected to grow in future years.

In 2018, just over $10 \mathrm{GW}$ of projects reached financial close. In Europe, 14 projects, representing 6,052 MW of capacity, reached financial close in 2018. In the Asian market, 17 projects, representing 4,178 MW of capacity, reached financial close. In total, there are about $19 \mathrm{GW}$ of projects that have reached financial close or are under construction as of 2018.

Figure 14 provides a yearly estimate of new deployment based solely on the developer's estimation of when they expect their project to be commissioned. Although a project developer may not always be at liberty to disclose detailed updates or information related to their exact deployment schedule, the developer COD data is a rough proxy for near-term deployment. In 2019, annual capacity additions are expected to be dominated by the United Kingdom and China.

Although most deployments until 2024 are located in the United Kingdom and China, other European countries, such as Germany, the Netherlands, and Denmark, continue to approve new projects to meet their national renewable or offshore wind targets. Based on only the projects reporting COD dates in Figure 14, these new additions would result in approximately $44 \mathrm{GW}$ of new capacity from 2019 through 2024.

\footnotetext{
${ }^{42}$ Generally, a project is assumed to be commissioned 2 years after construction begins.
} 


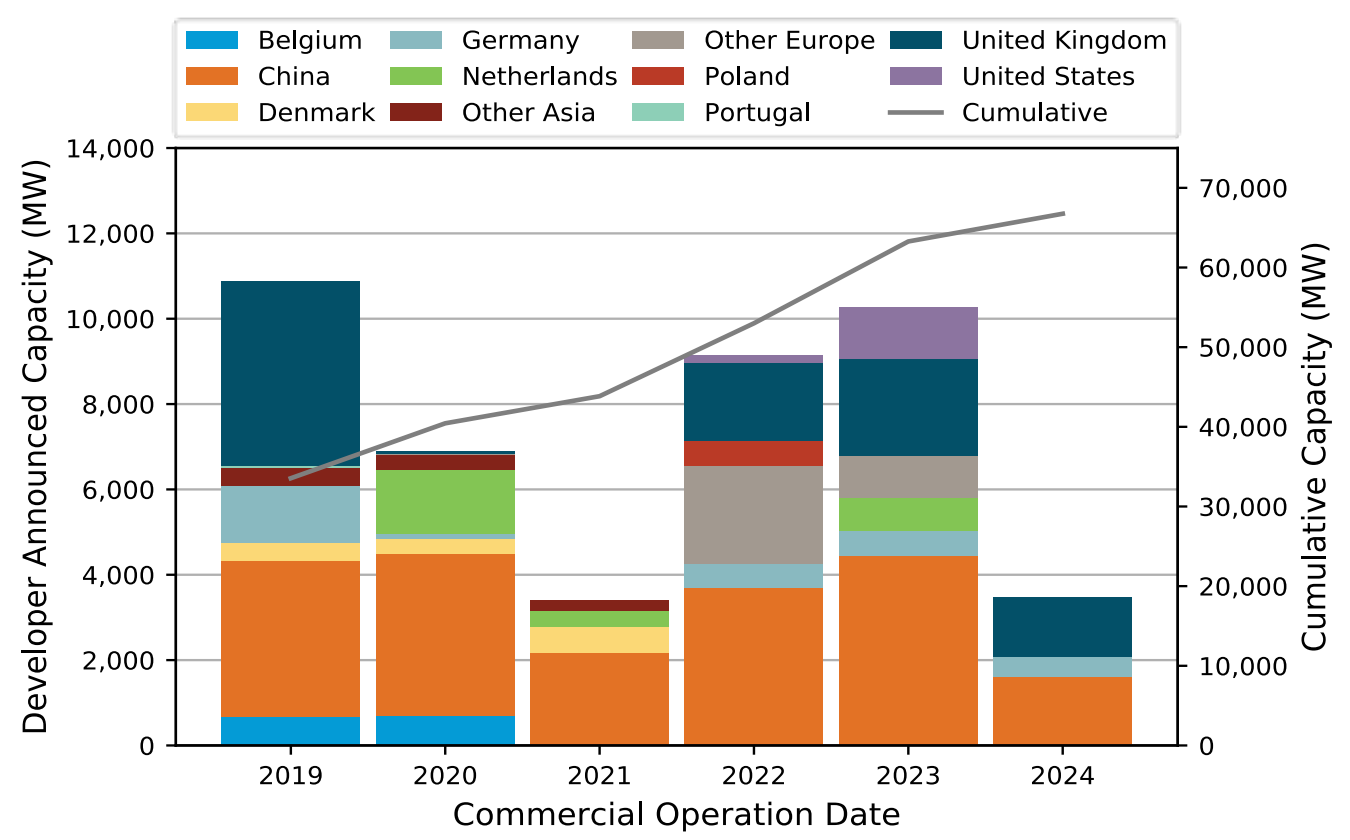

Figure 14. Developer-announced offshore wind capacity through 2024 for projects with financial close

Figure 15 extends Figure 12 beyond the present day using the data shown in Figure 14 as a proxy to estimate near-term offshore wind deployment through 2024.

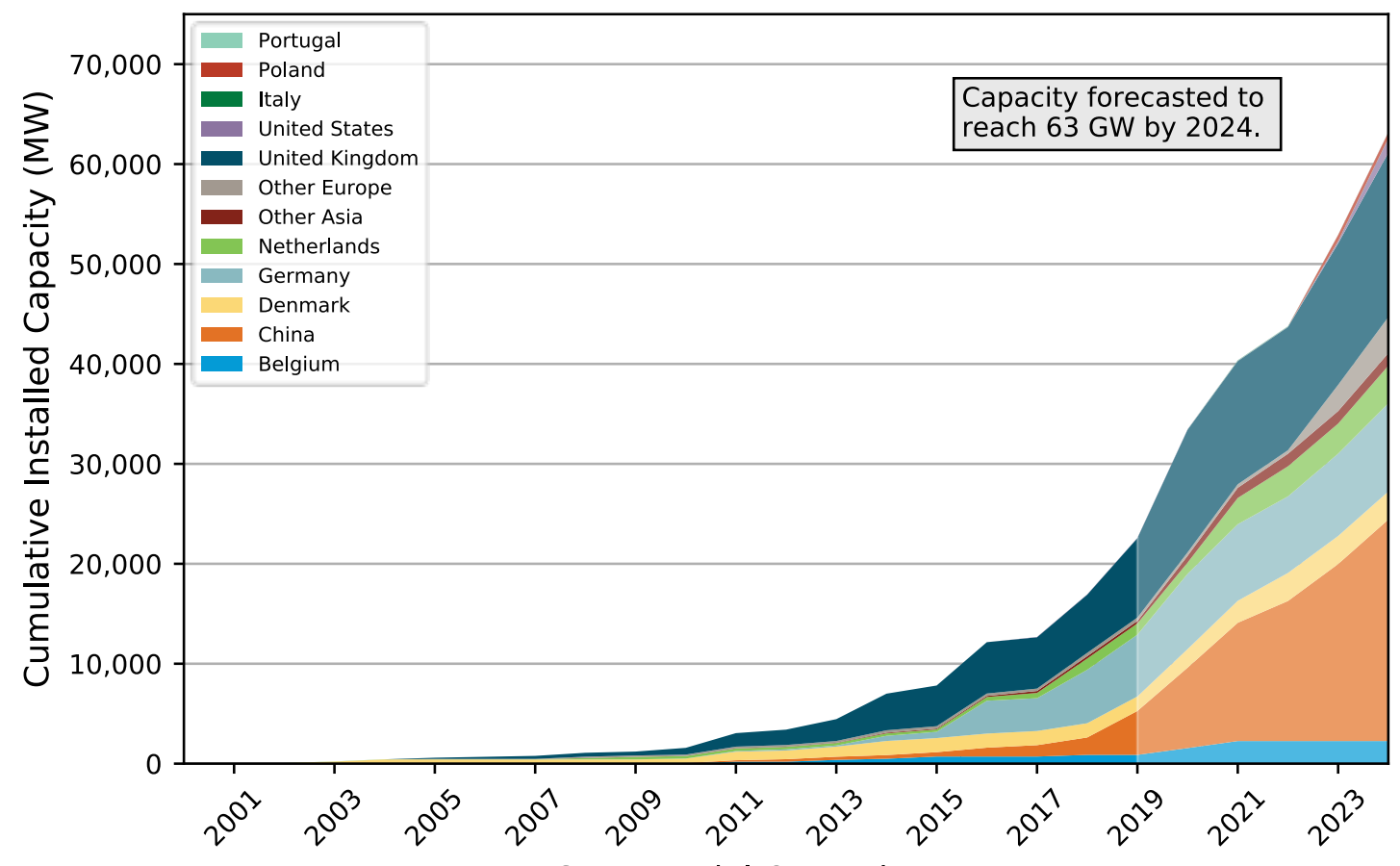

Commercial Operation Date

Figure 15. Estimated 2024 cumulative offshore wind capacity by country based on a developer-announced COD (shaded areas represent forecasted deployments) 
The figure shows steady or accelerated growth for the next 5 years. Although new markets, such as Poland or Portugal, could help maintain the European share of total global offshore wind capacity, dramatic growth in Asian markets indicates that China may represent almost $50 \%$ of the cumulative global capacity in the next 5 years. In aggregate, cumulative global offshore wind deployment is expected to reach over $63 \mathrm{GW}$ by 2024 .

\subsubsection{Total Global Pipeline}

Figure 16 shows the global capacity of the operating and announced development pipeline for all offshore wind projects by region to be $272 \mathrm{GW}$, compared to approximately $230 \mathrm{GW}$ in 2017 . The uptick is primarily attributed to more Asian projects entering the planning phase. This figure does not provide information about the likely timing of developments within the long-term pipeline, but provides overall announced capacity for all active projects recorded in the NREL OWDB. ${ }^{43}$ Generally, projects that are more advanced within the pipeline are more likely to reach COD and to be installed sooner than those at an earlier stage; however, international differences in regulatory structure can result in a wide range of development timelines. The global project pipeline illustrates that the majority of the world's installed projects and projects under advanced development are in Europe, but the majority of the world's potential future capacity is in Asia. Looking at project status, there are approximately $63 \mathrm{GW}$ of approved projects in the global pipeline - roughly three times the amount of capacity currently installed today. If all of the approved capacity gets built, the dramatic expansion of the global market will require the further maturation of global supply chains, expansion of manufacturing capabilities, and new installation vessels.

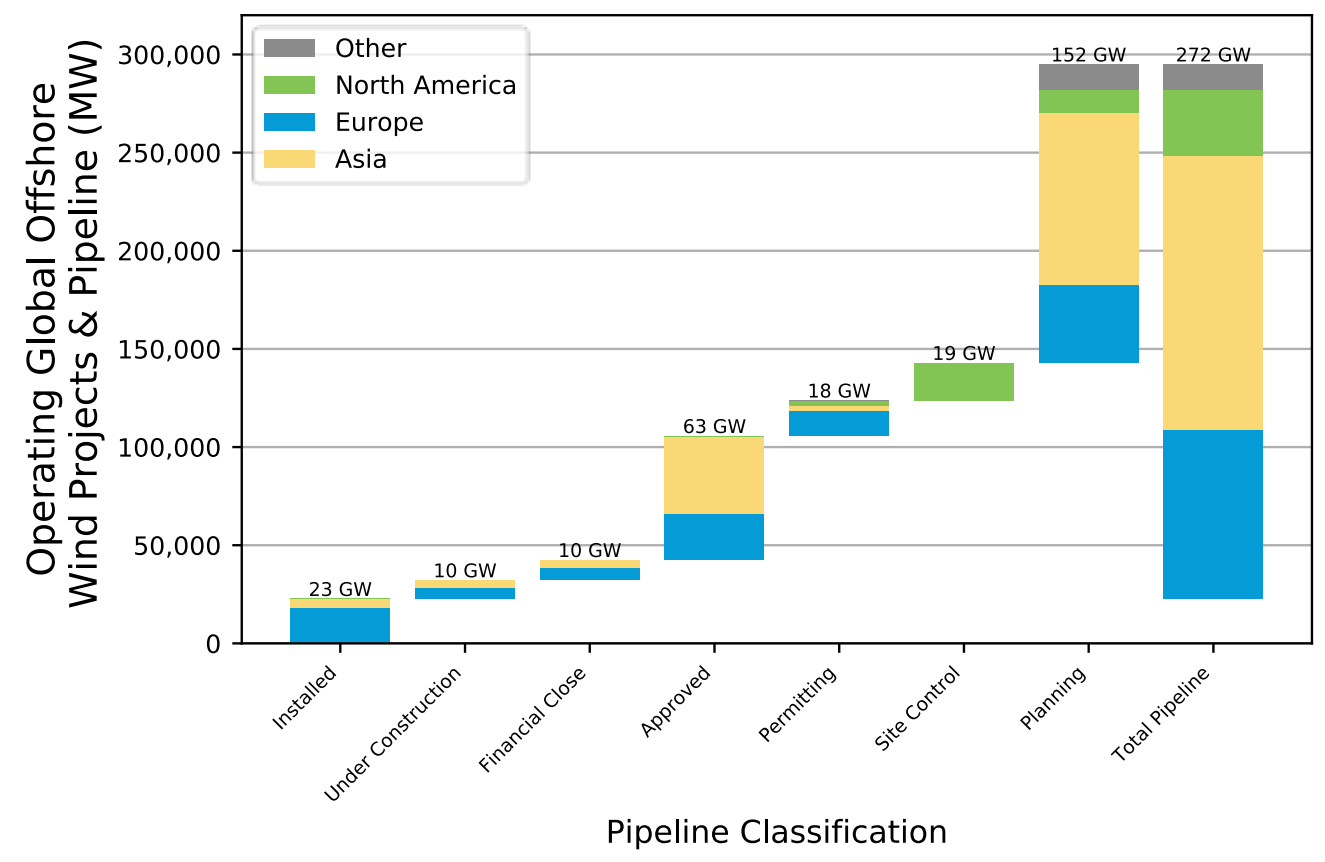

Figure 16. Total global pipeline by status

\footnotetext{
${ }^{43}$ The data in Figure 16 do not include projects that are dormant, cancelled, decommissioned, or development zones.
} 


\subsubsection{Medium-Term Projections}

Figure 17 illustrates medium-term forecasts of global offshore deployment broken down by country from 2018 through 2030.

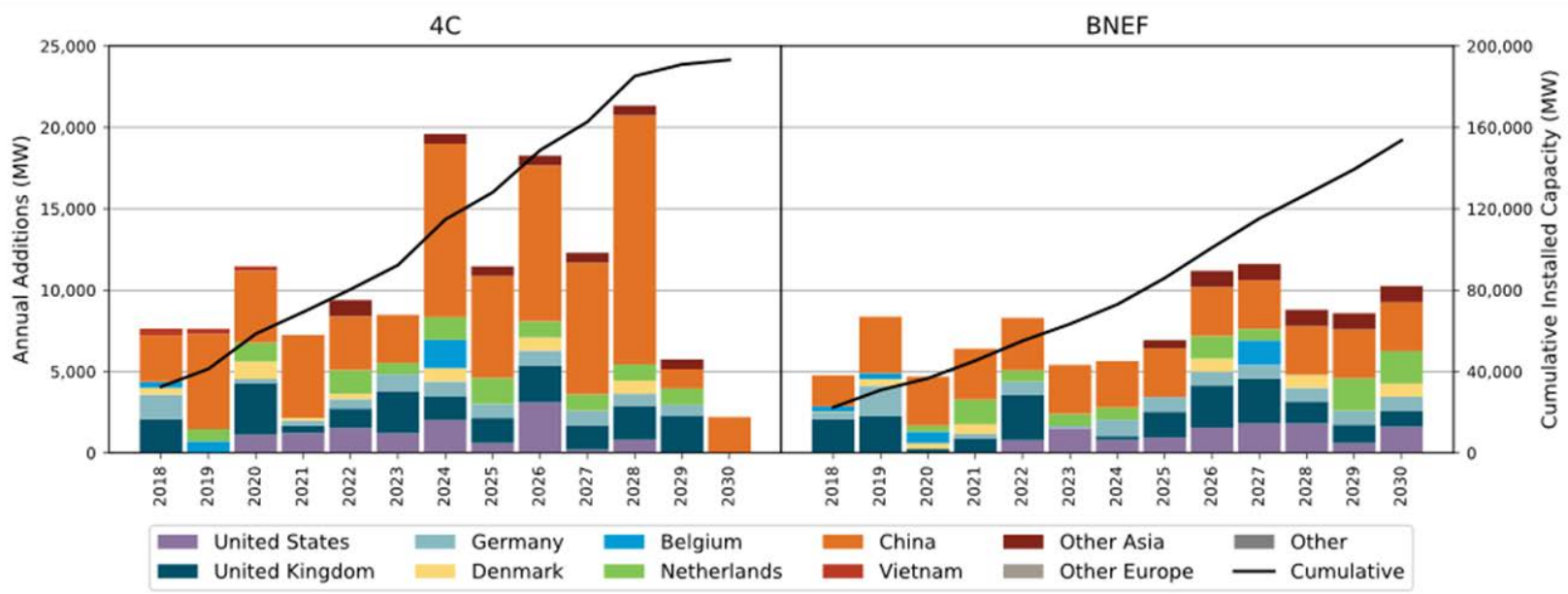

Figure 17. Medium-term wind capacity forecasts by country through 2030

In the figure, two independent forecasts are shown; one by BNEF (2018a) and one by 4C Offshore (2018), which estimate the future growth of the global offshore wind industry. BNEF forecasts offshore wind will reach $154 \mathrm{GW}$ by 2030, whereas 4C Offshore estimates a projected deployment level of $193 \mathrm{GW}$ by 2030 . Both forecasts are provided to illustrate the variability and uncertainty associated with longer-range deployment estimates.

Like the near-term forecast to 2024, the most striking shift in offshore wind market dynamics in the 2030 forecast scenarios is the estimated growth of the Chinese market. Both forecasts expect China will cumulatively deploy between $41 \mathrm{GW}$ and $84 \mathrm{GW}$ by 2030. Forecasts also predict European developers will continue to incrementally build projects at a similar rate relative to today, with Europe holding roughly $47 \%$ of the total installed global offshore wind capacity by 2030 . China itself is expected to represent $27 \%$ of the total 2030 installed capacity with the remaining other Asian countries (e.g., Korea, Japan, and Vietnam) accounting for $19 \%$. Depending on the forecast scenario (4C Offshore or BNEF), the U.S. proportion of installed capacity could range from $6.5 \%$ to about $8.5 \%$ of the global total by 2030 .

\subsection{Floating Offshore Wind Market Trends}

The floating offshore wind market is still driven by the prospect of accessing a much larger resource area with high-quality wind resources, but in water depths that are too deep (nominally greater than $60 \mathrm{~m}$ ) for conventional fixed-bottom technologies. In the United States, more than $58 \%$ of the total technical offshore wind resource is located in water depths greater than $60 \mathrm{~m}$, and in Europe that number is $80 \%$ (Musial et al. 2016; WindEurope 2018). Globally, the development of a floating offshore wind market is emerging quickly as experience and knowledge are gained from pilot projects in Europe, Asia, and North America. This pilot phase, which should be mostly operational by 2022 , is expected to inform the development of cost-effective commercial-scale projects that may be possible by as early as 2025 .

\subsubsection{Existing Floating Projects}

There are currently eight floating offshore wind projects installed around the world representing $46 \mathrm{MW}$ of capacity. Five projects (37 MW) are installed in Europe and three ( $9 \mathrm{MW})$ are in Asia. There are an additional 14 projects representing approximately $200 \mathrm{MW}$ that are currently under construction or have achieved either financial close or regulatory approval. Two projects $(488 \mathrm{MW})$ have advanced to the permitting phase of development, and another 14 are in the early planning stages (4,162 MW). Overall, the 2018 global floating offshore wind pipeline represents approximately 4,888 MW of capacity, growing by 2,000 MW relative to the 
2017 Offshore Wind Technologies Market Report Update. Figure 18 illustrates the current offshore wind market pipeline in terms of market timeline, proposed project size, water depth, and host country. The figure illustrates how the floating offshore wind market evolved from small-scale, single-turbine prototypes (20092015) to multiturbine demonstration projects (2016-2022). Post-2022, the first large-scale floating projects are expected to become commercially viable.

Each of the 38 projects shown in Figure 18 are listed in Table 11, which also includes the project status, capacity developer, and substructure type.

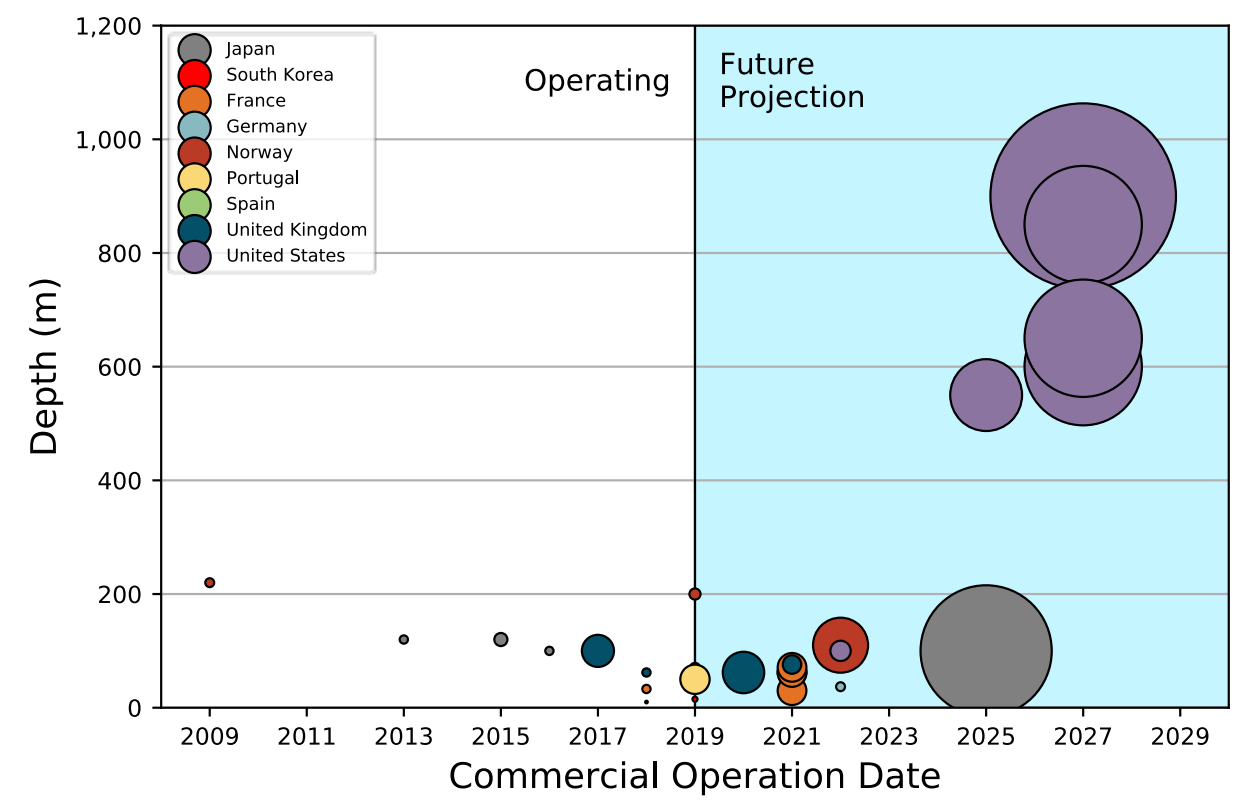

Figure 18. Global floating offshore wind pipeline 
Table 11. Current Floating Offshore Wind Projects in Pipeline

\begin{tabular}{|c|c|c|c|c|c|c|c|c|c|}
\hline Region & Project & Country & $\begin{array}{l}\text { Pipeline } \\
\text { Status }\end{array}$ & COD & $\begin{array}{c}\text { Capacity } \\
\text { (MW) }\end{array}$ & $\begin{array}{l}\text { Water } \\
\text { Depth } \\
\text { (m) }\end{array}$ & Developer & $\begin{array}{c}\text { Turbine } \\
\text { Rating } \\
\text { (MW) }\end{array}$ & Substructure \\
\hline \multirow{13}{*}{ Asia } & $\begin{array}{c}\text { Fukushima Floating } \\
\text { Offshore Wind Farm } \\
\text { Demo Phase } 1\end{array}$ & Japan & Installed & 2013 & 2 & 120 & $\begin{array}{l}\text { Marubeni } \\
\text { Corporation }\end{array}$ & 2 & Semisubmersible \\
\hline & $\begin{array}{c}\text { Fukushima Floating } \\
\text { Offshore Wind Farm } \\
\text { Demo Phase } 2\end{array}$ & Japan & Installed & 2015 & 5 & 120 & $\begin{array}{l}\text { Marubeni } \\
\text { Corporation }\end{array}$ & 5 & Semisubmersible \\
\hline & $\begin{array}{l}\text { Sakiyama 2-MW } \\
\text { Floating Wind } \\
\text { Turbine }\end{array}$ & Japan & Installed & 2016 & 2 & 100 & $\begin{array}{c}\text { TODA } \\
\text { Corporation }\end{array}$ & 2 & Spar \\
\hline & $\begin{array}{c}\text { Kitakyushu - New } \\
\text { Energy Development } \\
\text { Organization (NEDO) }\end{array}$ & Japan & $\begin{array}{c}\text { Under } \\
\text { Construction }\end{array}$ & 2019 & 3 & 70 & NEDO/Ideol & 3 & Semisubmersible \\
\hline & Hitachi Zosen & Japan & Permitting & 2024 & 400 & - & Equinor Hitachi & TBD & Semisubmersible \\
\hline & Macquarie Japan & Japan & Planning & 2025 & 500 & 100 & Macquarie & TBD & TBD \\
\hline & $\begin{array}{l}\text { Ulsan } 750 \text {-kilowatt } \\
\text { Floating Demo }\end{array}$ & $\begin{array}{l}\text { South } \\
\text { Korea }\end{array}$ & $\begin{array}{l}\text { Financial } \\
\text { Close }\end{array}$ & 2019 & 0.75 & 15 & Consortium & 0.75 & Semisubmersible \\
\hline & $\begin{array}{c}\text { Donghae KNOC - } \\
\text { Equinor }\end{array}$ & $\begin{array}{l}\text { South } \\
\text { Korea }\end{array}$ & Planning & 2027 & TBD & TBD & Equinor/KNOC & TBD & TBD \\
\hline & $\begin{array}{c}\text { Ulsan Shell, Coens, } \\
\text { Hexicon }\end{array}$ & $\begin{array}{l}\text { South } \\
\text { Korea }\end{array}$ & Planning & 2027 & 200 & TBD & $\begin{array}{l}\text { Shell/Coens/ } \\
\text { Hexicon }\end{array}$ & TBD & Semisubmersible \\
\hline & Ulsan Macquarie & $\begin{array}{l}\text { South } \\
\text { Korea }\end{array}$ & Planning & 2027 & 200 & TBD & Macquarie & TBD & TBD \\
\hline & Ulsan SK E\&S - CIP & $\begin{array}{l}\text { South } \\
\text { Korea }\end{array}$ & Planning & 2027 & 200 & TBD & SK E\&S/CIP & TBD & TBD \\
\hline & $\begin{array}{l}\text { Ulsan KFWind - } \\
\text { Principle Power - } \\
\text { Wind Power Korea }\end{array}$ & $\begin{array}{l}\text { South } \\
\text { Korea }\end{array}$ & Planning & 2027 & 200 & TBD & KFWind/PPI/WPK & TBD & Semisubmersible \\
\hline & Floating W1N & Taiwan & Planning & 2025 & 500 & & Eolfi/Cobra & TBD & TBD \\
\hline \multirow{8}{*}{ Europe } & $\begin{array}{c}\text { EOLINK } 1 / 10 \text {-scale } \\
\text { prototype }\end{array}$ & France & Installed & 2018 & 0.2 & 10 & EOLINK S.A.S. & 0.2 & Semisubmersible \\
\hline & Floatgen Project & France & Installed & 2018 & 2 & 33 & Ideol & 2 & Barge \\
\hline & Groix Belle Ille & France & Approved & 2021 & 24 & 62 & EOLFI & 6 & Semisubmersible \\
\hline & $\begin{array}{c}\text { Provence Grand } \\
\text { Large }\end{array}$ & France & Approved & 2021 & 24 & 30 & EDF & 8 & $\begin{array}{l}\text { Tension Leg } \\
\text { Platform }\end{array}$ \\
\hline & Eolmed & France & Approved & 2021 & 24 & 62 & Ideol & 6.2 & Barge \\
\hline & $\begin{array}{l}\text { Les Eoliennes Flotant } \\
\text { du Golfe du Lion }\end{array}$ & France & Approved & 2021 & 24 & 71 & $\begin{array}{c}\text { Engie, EDPR, } \\
\text { Caisse de Depots }\end{array}$ & 6 & Semisubmersible \\
\hline & $\begin{array}{c}\text { GICON } \\
\text { Schwimmendes } \\
\text { Offshore Fundament } \\
\text { SOF Pilot }\end{array}$ & Germany & $\begin{array}{l}\text { Financial } \\
\text { Close }\end{array}$ & 2022 & 2.3 & 37 & GICON & 2.3 & $\begin{array}{l}\text { Tension Leg } \\
\text { Platform }\end{array}$ \\
\hline & Hywind - Demo & Norway & Installed & 2009 & 2.3 & 220 & $\begin{array}{l}\text { UNITECH } \\
\text { Offshore }\end{array}$ & 2.3 & Spar \\
\hline
\end{tabular}




\begin{tabular}{|c|c|c|c|c|c|c|c|c|c|}
\hline Region & Project & Country & $\begin{array}{l}\text { Pipeline } \\
\text { Status }\end{array}$ & COD & $\begin{array}{c}\text { Capacity } \\
\text { (MW) }\end{array}$ & $\begin{array}{c}\text { Water } \\
\text { Depth } \\
\text { (m) }\end{array}$ & Developer & $\begin{array}{c}\text { Turbine } \\
\text { Rating } \\
\text { (MW) }\end{array}$ & Substructure \\
\hline & $\begin{array}{c}\text { TetraSpar } \\
\text { Demonstrator }\end{array}$ & Norway & $\begin{array}{l}\text { Financial } \\
\text { Close }\end{array}$ & 2019 & 3.6 & 200 & $\begin{array}{l}\text { Innogy, Shell, } \\
\text { Stiesdal }\end{array}$ & 3.6 & Semisubmersible \\
\hline & Hywind Tampen & Norway & Permitting & 2022 & 88 & 110 & Equinor & 8 & Spar \\
\hline & NOAKA & Norway & Planning & 2023 & TBD & 130 & Equinor/Aker BP & TBD & TBD \\
\hline & $\begin{array}{l}\text { WindFloat Atlantic } \\
\text { (WFA) }\end{array}$ & Portugal & $\begin{array}{l}\text { Financial } \\
\text { Close }\end{array}$ & 2019 & 25 & 50 & WindPlus S.A. & 8 & Semisubmersible \\
\hline & DemoSATH - BIMEP & Spain & Approved & 2020 & 2 & 68 & $\begin{array}{l}\text { Saitec Offshore } \\
\text { Technologies }\end{array}$ & TBD & Semisubmersible \\
\hline & $\begin{array}{l}\text { X1 Wind prototype } \\
\text { PLOCAN }\end{array}$ & Spain & Approved & 2021 & TBD & 62 & X1 Wind & TBD & $\begin{array}{l}\text { Tension Leg } \\
\text { Platform }\end{array}$ \\
\hline & $\begin{array}{c}\text { Floating Power Plant } \\
\text { PLOCAN }\end{array}$ & Spain & Approved & 2021 & TBD & 62 & FPP & $8 \mathrm{MW}$ & $\begin{array}{l}\text { Hybrid Wave Power } \\
\text { Semisubmersible }\end{array}$ \\
\hline & $\begin{array}{c}\text { Hywind Scotland } \\
\text { Pilot Park }\end{array}$ & $\begin{array}{l}\text { United } \\
\text { Kingdom }\end{array}$ & Installed & 2017 & 30 & 100 & Equinor & 6 & Spar \\
\hline & Dounreay Tri & $\begin{array}{l}\text { United } \\
\text { Kingdom }\end{array}$ & Approved & 2021 & 10 & 76 & Hexicon & 5 & Semisubmersible \\
\hline & $\begin{array}{l}\text { Kinkardine Offshore } \\
\text { Wind Farm Phase } 1\end{array}$ & $\begin{array}{l}\text { United } \\
\text { Kingdom }\end{array}$ & Installed & 2018 & 2 & 62 & Cobra & $2 \mathrm{MW}$ & Semisubmersible \\
\hline & $\begin{array}{l}\text { Kinkardine Offshore } \\
\text { Wind Farm Phase } 2\end{array}$ & $\begin{array}{l}\text { United } \\
\text { Kingdom }\end{array}$ & $\begin{array}{c}\text { Under } \\
\text { Construction }\end{array}$ & 2020 & 50 & 62 & Cobra & $9.5 \mathrm{MW}$ & Semisubmersible \\
\hline \multirow{6}{*}{$\begin{array}{c}\text { North } \\
\text { America }\end{array}$} & Castle Wind & $\begin{array}{l}\text { United } \\
\text { States }\end{array}$ & Planning & 2027 & 1,000 & 900 & $\begin{array}{c}\text { EnBW/Trident } \\
\text { Winds }\end{array}$ & $8+$ & Semisubmersible \\
\hline & $\begin{array}{l}\text { Redwood Coast } \\
\text { Energy }\end{array}$ & $\begin{array}{l}\text { United } \\
\text { States }\end{array}$ & Planning & 2025 & 150 & 550 & EDPR/PPI & $8+$ & Semisubmersible \\
\hline & Aqua Ventus I & $\begin{array}{l}\text { United } \\
\text { States }\end{array}$ & Planning & 2022 & 12 & 100 & $\begin{array}{l}\text { University of } \\
\text { Maine }\end{array}$ & $6+$ & Semisubmersible \\
\hline & Oahu North & $\begin{array}{l}\text { United } \\
\text { States }\end{array}$ & Planning & 2027 & 400 & 850 & AW Wind & $6+$ & Semisubmersible \\
\hline & Oahu South & $\begin{array}{l}\text { United } \\
\text { States }\end{array}$ & Planning & 2027 & 400 & 600 & AW Wind & $6+$ & Semisubmersible \\
\hline & Progression Wind & $\begin{array}{l}\text { United } \\
\text { States }\end{array}$ & Planning & 2027 & 400 & 650 & Progression Wind & $6+$ & Semisubmersible \\
\hline
\end{tabular}




\subsubsection{Global Floating Market Assessment}

The global offshore wind market continues to mature and show signs that it will accelerate its growth in the future. Major developments and trends in 2018 include the following.

- Initial pilot and demonstration projects have validated functionality of floating technologies and encouraged further turbine upscaling. Principle Power indicated that its 25-MW WindFloat Atlantic project in Portugal on its tri-hull asymmetrical semisubmersible substructures will be paired with three MHI Vestas V164-8.4 MW turbines, and the 50-MW Kincardine Floating Offshore Wind Park will use five MHI Vestas V164-9.5 MW turbines and one V80-2.0 MW turbine. Equinor also intends to deploy 8-MW (and above) turbines at its proposed 88-MW Tampen project aimed at powering two offshore oil and gas rigs in Norway. Similar to fixed-bottom technologies, floating systems seek larger turbines to help lower project costs (see Section 4).

- Ideol installed a 2-MW demonstration project and France approved four demonstration projects. Ideol's 2-MW Floatgen (dampening pool barge ${ }^{44}$ ) demonstration project was successfully installed $2 \mathrm{~km}$ off Le Crosic and connected to the grid in September 2018. The European Commission has offered financial support and the French government has approved four 24-MW demonstration projects: Groix Belle Ille in the Atlantic as well as Golfe du Lion, Eolmed, and Provence Grand Large on the Mediterranean (European Commission 2019).

- Interest in offshore wind on the West Coast of the United States increased in 2018. California's ambitious $100 \%$ renewable energy goals could necessitate the development of floating offshore wind projects in water depths up to 1,000 meters $(\mathrm{m})$ (see Section 2). Two unsolicited offshore wind project applications have been filed with BOEM including Redwood Coast Energy (150 MW) and Castle Wind $(1,000 \mathrm{MW})$. Because competitive commercial interest has been established, BOEM initiated three Call Areas (two are around these projects) and is accepting public comments on how to best shape potential future lease areas.

- Nascent Asian markets showed strong interest in floating wind. Japan has been interested in offshore wind since 2011 and installed some of the first prototypes using government funding appropriated after the Fukushima nuclear accident. New floating projects in Japan look increasingly promising now that the country has developed offshore wind deployment policies. In the near term, Japan's New Energy and Technology Development Organization announced that it is constructing a 3-MW demonstration project. Equinor has signed a memorandum of understanding with Korea National Oil Corporation to develop a floating project near the Donghae gas platform that is $58 \mathrm{~km}$ off the coast of Ulsan City, South Korea. Ulsan Metropolitan City and National Government also signed four memorandums of understanding with developers ${ }^{45}$ to each develop 200-MW floating projects with a COD of 2023 (Quest Floating Wind Energy 2019).

\footnotetext{
${ }^{44} \mathrm{~A}$ dampening pool barge is a shallow-draft, buoyant foundation with a central opening that damps out platform motion caused by wave action.

${ }^{45}$ Developers include 1) Macquarie, 2) CIP and SK E\&C, 3) PPI and Wind Power Korea, and 4) Shell, Coens, and Hexicon.
} 


\section{Offshore Wind Technology Trends}

Technology advancements have played a key role in achieving the cost reductions experienced over the past few years that are enabling offshore wind energy to compete without subsidies in some energy markets. New technology and technical innovations are leading the industry to both lower costs and create new market regions. Continued cost reductions are allowing fixed-bottom offshore wind systems to compete in high-priced energy markets today, and floating wind technology, when matured, can open new regions that are currently inaccessible with existing technology (Gilman et al. 2016; WindEurope 2018). For many years, offshore wind technology advancements were measured by metrics, such as greater water depths and distances from shore (Beiter et al. 2016). More revolutionary technology advancements, such as floating wind turbines, promise larger payoffs in terms of dramatically greater siting options and wide-ranging increases in global electricity market penetration.

Using NREL's OWDB described in Section 1, this section relies substantially on empirical data for planned projects advancing through the pipeline to provide insight into global technology siting trends through 2024. The OWDB also provides insight regarding offshore wind turbine capacities, substructures, electric infrastructure, and logistical approaches for construction and maintenance activities. Much of the discussion is focused on fixed-bottom technologies, although floating technologies are also included.

\subsection{Siting Trends for Global Offshore Wind Projects}

Here we update trends observed in offshore wind fixed-bottom technology related to site characteristics of water depth and distance from shore. Figure 19 provides industry trends of four parameters - depth, distance, project status, and project size - and shows these trends for global offshore wind projects that have, at a minimum, advanced to the site-control phase. Global projects are color-coded by the project phase they have advanced to in the pipeline.

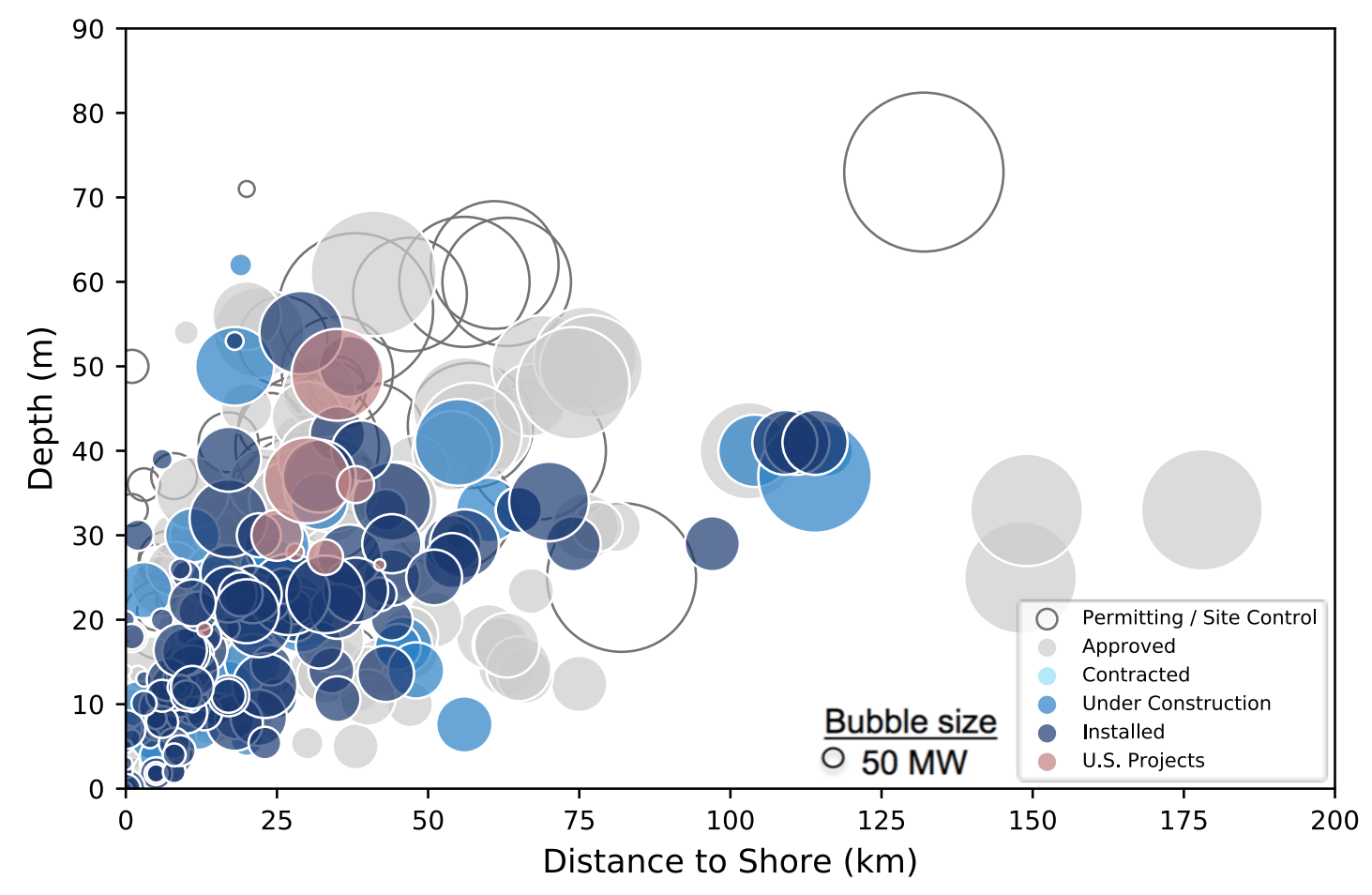

Figure 19. Fixed-bottom offshore wind project depths and distance to shore 
In the figure, the project size is indicated by the diameter of the bubbles. The relative scale is shown with a representative 50-MW project in the key. This figure indicates a possible global trend toward larger projects (i.e., larger bubble sizes) sited farther from shore (i.e., the largest bubbles are at the 1,000-MW scale), particularly for those projects in the permitting and approval phase of development. Projects located further distances from shore (as far as $200 \mathrm{~km}$ ) are enabled by the shallow bathymetry of the North Sea, where projects can be sited far from shore while still using fixed-bottom foundations.

Also included are the eight U.S. offshore wind fixed-bottom projects that have a viable pathway to an offtake agreement, have secured site control, and have significantly advanced in the permitting and regulatory process. ${ }^{46}$ These projects have similar characteristics with respect to water depth and distance to shore; however, given the limited sample, it is difficult to judge longer-term trends. There are over $20 \mathrm{GW}$ of capacity in the auctioned lease areas but distances from shore do not exceed $60 \mathrm{~km}$ in these areas and depths range from 20 to $65 \mathrm{~m}$ (Musial et al. 2013; BOEM 2019f).

Also, projects sited too close to shore can trigger public acceptance issues. Turbines sited beyond a certain distance from shore will generally be less visible and could raise fewer objections. This "acceptable" distance will vary depending on many factors including the land-based terrain and demographics, turbine scale, climate, and proximity to populations (Krueger et al. 2011). In the United States, public acceptance issues led to the demise of the first proposed commercial-scale U.S. project, Cape Wind, which may have contributed to BOEM's informal recommendation that new WEAs be at least 10 nautical miles $(\mathrm{nm})$ from the shore (BOEM 2018). Therefore, with respect to distance from shore, near-term U.S. projects are likely to fall in a narrower vertical band (18-60 km depth) in Figure 19 than the global spread of distances. With respect to depth, some of the lease areas (e.g., Massachusetts WEA) have significant depths between 50 and $65 \mathrm{~m}$, where projects will likely be built (Musial et al. 2013). Therefore, these depths up to $65 \mathrm{~m}$ in the existing WEAs will likely result in U.S. projects having slightly higher average depths than current European projects.

However, to judge a project's cost and complexity, it is more important to consider the distance to critical infrastructure than distance to shore. As more projects are permitted and built, developers may have more difficulty finding suitable grid connection points, thereby making export cable runs longer. Further, the cost of the electrical infrastructure for a wind project depends more on the length of the export cable than how far it is offshore. Similarly, the distance to construction and service ports will also be a strong cost factor, because turbine access, as well as construction and operation and maintenance (O\&M) costs are directly related (Beiter et al. 2016).

As the industry matures, new technology and experience allows access to greater water depths, but projects with fixed-bottom foundations will pay a premium to access deeper water (Beiter et al. 2016). Floating foundations promise relief from water depth cost penalties, but it is still too early to fully understand these costs relative to fixed-bottom foundations on a commercial scale (Musial et al. 2016). However, if demand for offshore wind continues to increase, higher competing use constraints nearshore (e.g., fishing) may make it necessary to site some future Call Areas farther from shore, and therefore in deeper water where floating technology would be needed (Musial et al. 2016).

In Figure 19, the trends toward distance from shore or deeper water are not clear because new additions are difficult to track on a time-dependent basis. Figure 20 and Figure 21 show distance from shore and water depth as independent variables as a function of time (year of commissioning) for installed projects to help illuminate these trends better. These plots show the span of actual projects built for each year from 2000 to 2018, and projections that were made based on data from projects in the pipeline out to 2024. These data, provided for each year, indicate the capacity-weighted averages, and the range of all projects showing the highest and lowest values. For most years, the number of projects is too small to provide statistical significance, but the overall trends out to 2024 can be inferred. Figure 20 indicates that the trend toward greater distances from shore may not be very strong. The data show there is a wider degree of variability from year to year, due, in

${ }^{46}$ Note Aqua Ventus I is not shown because it is a floating project with different metrics for water depth. 
part, to enabling technologies like high-voltage direct current (HVDC) transmission, which has been used in the North Sea to export power long distances to shore in several German projects.

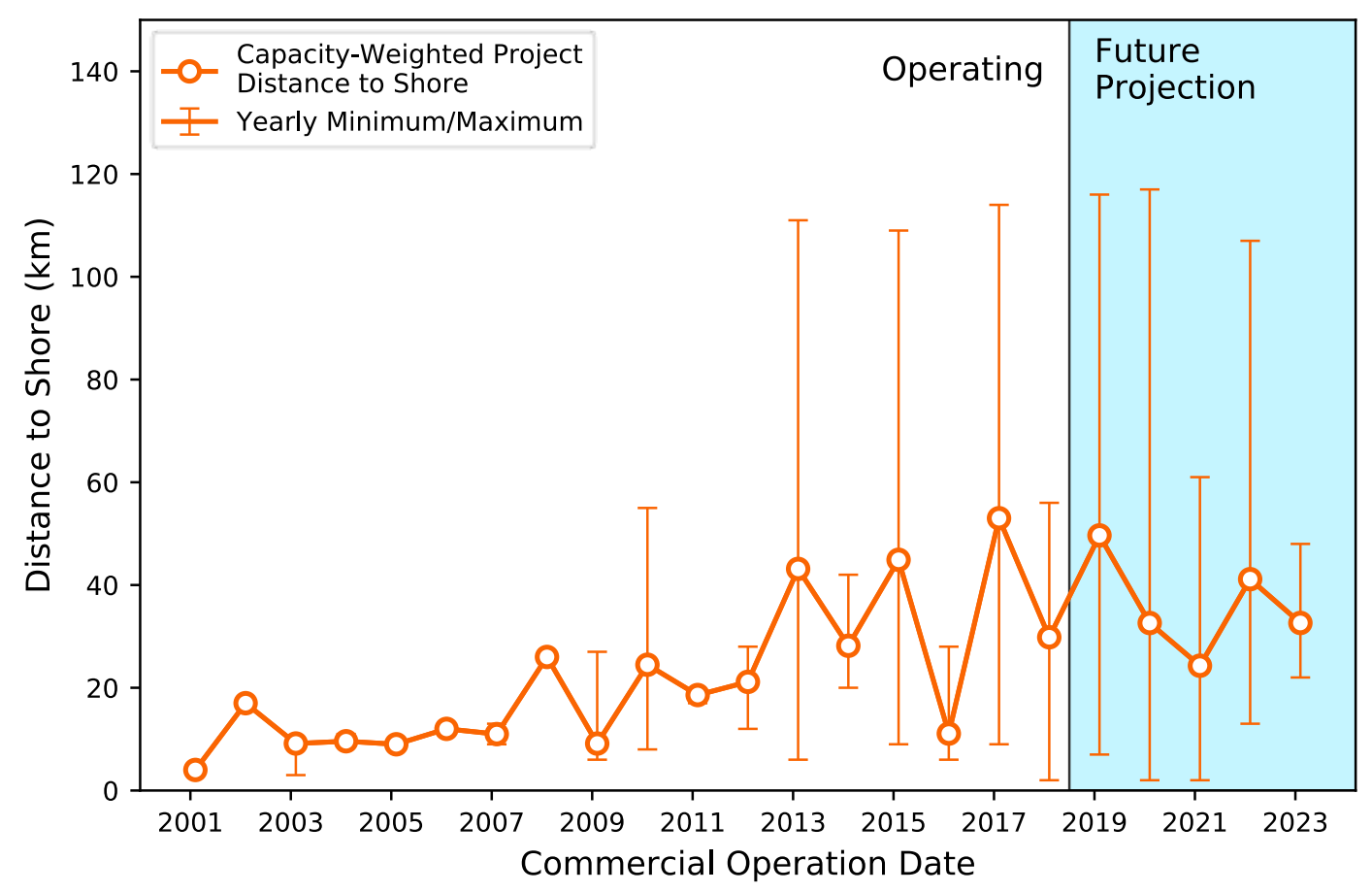

Figure 20. Project distance from shore trend to 2024

Similarly, Figure 21 shows the gradual trend in the global data toward greater water depths.

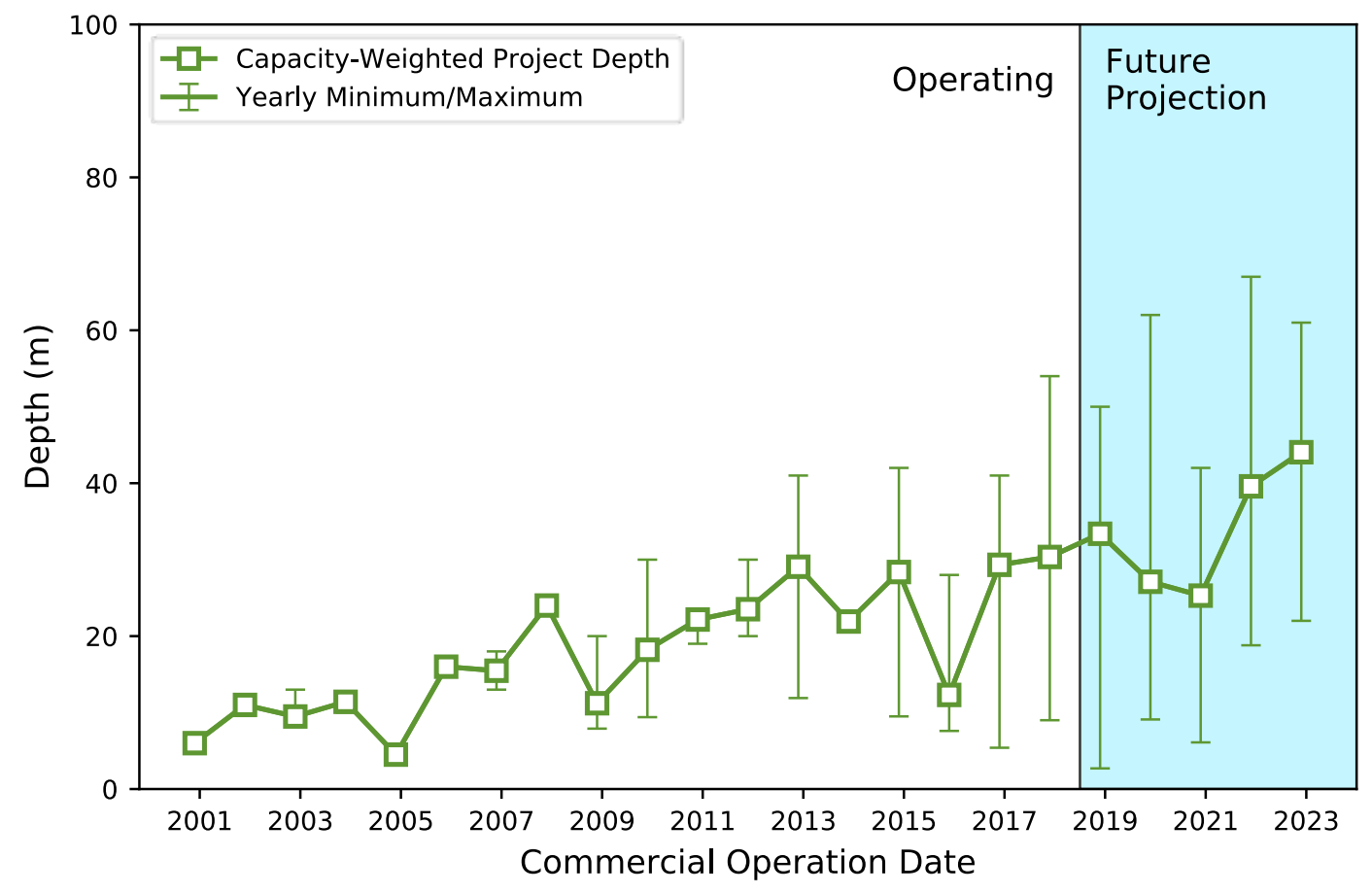

Figure 21. Project depth trend to 2024 
The project trend toward deeper water is more defined than the trend toward greater distances to shore. Substructure designs have incrementally improved to overcome depth limits, thereby allowing access to more sites. Some deployments have already been successfully made at 50-m depths, and installations up to 60-m depths and beyond are planned before 2024 (The Crown Estate 2018). In the United States, some of the foundations at the Vineyard Wind site will be near a 50-m water depth (Vineyard Wind 2018a).

\subsection{Offshore Wind Turbines}

Here we address the trends in offshore wind turbine technology. In 2018, the industry's turbine manufacturers committed more confidently to increases in turbines size, indicating that a new 10-MW to 12-MW platform is under development for the next generation of turbines. This growth is being spurred by overall system cost reductions and energy production improvements associated with larger turbines. In addition, as the industry expands toward the Asian market (especially Taiwan, which committed to $5.4 \mathrm{GW}$ earlier this year), turbine OEMs are beginning a serious effort to adapt turbines to extreme loads that may be generated by typhoons and seismic events.

\subsubsection{Offshore Wind Turbine Technology}

Offshore wind turbines are generally much larger than their land-based counterparts. Figure 22 shows global offshore wind turbine trends since 2000 along with the capacity-weighted ${ }^{47}$ average turbine rating (blue bars; left axis), capacity-weighted average rotor diameter (green line; right axis), and capacity-weighted average hub height (orange line; right axis). Note that the future projection through 2023 for weighted average turbine capacity, rotor diameter, and hub height is based on only the subset of projects $(21,037 \mathrm{MW})$ that have announced an agreement or partnership with a turbine OEM. These projections show that turbines are expected to continue to grow over time.

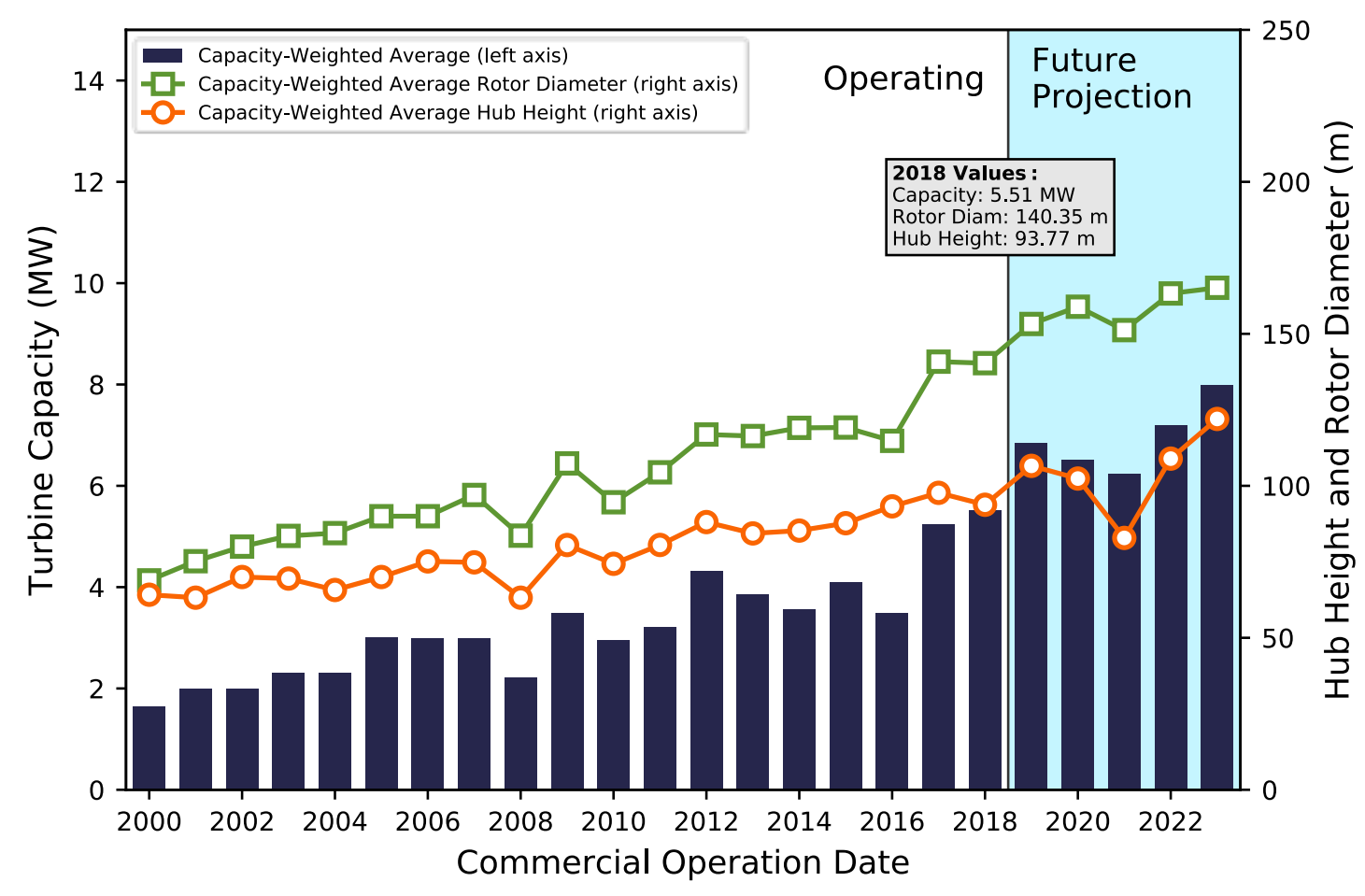

Figure 22. Offshore wind turbine rating, hub height, and rotor diameter

\footnotetext{
${ }^{47}$ A capacity-weighted average (weighted average) counts the contribution of a given characteristic (e.g., turbine rating) proportional to the amount of capacity (megawatts) the project delivers to the total capacity installed for a given year.
} 
Although Figure 22 shows a steady turbine size growth trend, tracking the current and historical commercial deployments may not be the best way of predicting the absolute size of future wind turbines. To understand the cutting edge of new technology development, it is better to look directly at the turbine prototype development stage. This is especially important for offshore wind because the pace of turbine growth is much faster than land-based technology, and larger turbines are affecting all aspects of industry development including the economics, infrastructure, balance of plant, siting, and supply chain.

Increasing turbine size is one of the major factors that has been attributed to the sharp cost declines in offshore wind. Larger capacity turbines generally yield lower balance-of-plant costs, fewer and faster installations, and lower maintenance, as well as more energy per unit of area. Recent cost information also indicates that in addition to these project cost-scaling benefits, unit turbine costs may not be rising with turbine capacity as originally predicted by early models, such as the 2006 NREL Cost and Scaling Model (Fingersh 2006; for more recent assessments see Graré et al. 2018; Valpy et al. 2017; BNEF 2018e). In fact, a higher turbine rating may not result in an increase in per-unit turbine capital expenditures (CapEx) (\$/kilowatt [kW]) at all. This new trend may potentially be a result of efforts by turbine manufacturers to manage increases in component mass using advanced engineering innovations and manufacturing methods, and through improved efficiencies in production and delivery. Therefore, a 6-MW wind turbine might have a similar cost per kilowatt as a 10MW turbine. This trend may be incentivizing industry's push to further increase turbine capacity.

Because of these cost advantages, on a project level, developers will generally select the largest turbine available. At the end of 2018, the largest turbine installed was the MHI Vestas V164-8.8 MW turbine at the Aberdeen Bay (European Offshore Wind Development Centre) project in Scotland, but the V174-9.5 is now available for commercial use and was ordered for the Baltic Eagle project in Germany. These MHI Vestas turbines follow another industry trend to extend the nameplate power rating of the current turbine technology platforms for 6- and 7-MW turbines as high as possible by increasing drivetrain/generator capacities while maintaining rotor size. Most turbine manufacturers have conformed to this design approach over the past few years. In doing so, this has driven up the specific power rating ${ }^{48}$ for these turbines, which could lower capacity factors in the interim while pushing the turbine technology platforms to their maximum energy extraction and load limits. These high specific power machines may still be well-suited for high wind sites in European waters but may not be the most efficient for lower wind speed sites in countries such as China, Japan, and Korea, and in the Great Lakes, mid-Atlantic, and South Atlantic regions of the United States.

In 2018, this trend in upscaling the existing turbine platforms was disrupted by the announcement of larger prototypes with increased rotor diameters - the next generation of offshore wind turbines on a new 10-MW to 12-MW technology platform. In March 2018, GE announced the 12-MW Haliade-X turbine, which has a prototype in production that is scheduled for installation in Rotterdam in 2019, and ready for market in 2021 (GE 2018b). The turbine is first in class, with a 12-MW direct-drive generator, 220-m rotor, and 140-m hub height. In January 2019, Siemens Gamesa announced the development of the SG10.0-193 DD turbine - a 10MW direct-drive turbine with a 193-m rotor-which is planned to be ready for market in 2022 (Siemens 2019). This turbine would be a substantial departure from Siemens Gamesa's current SG 8.0-167 DD platform. Other manufacturers, such as Senvion (formally Repower), have been following suit with their own development plans for turbines in the 12- to 16-MW range (Foxwell 2018c). From recent industry trade press, it appears that the industry is likely to increase turbine size beyond 12 MW (Windpower Monthly 2018; Snieckus 2018).

To illustrate the pace at which turbines are growing in the offshore wind industry, Figure 23 shows the average turbine capacity growth from Figure 22 along with data contrasting the capacities of the largest prototypes available in the first year they were built since 2000. The turbine prototypes shown in Figure 23 were all later commercialized and have become part of the industry's commercial pipeline (e.g., blue bars).

${ }^{48}$ Specific power is the nameplate power rating of a turbine divided by its rotor's swept area in Watts $/ \mathrm{m}^{2}$. 


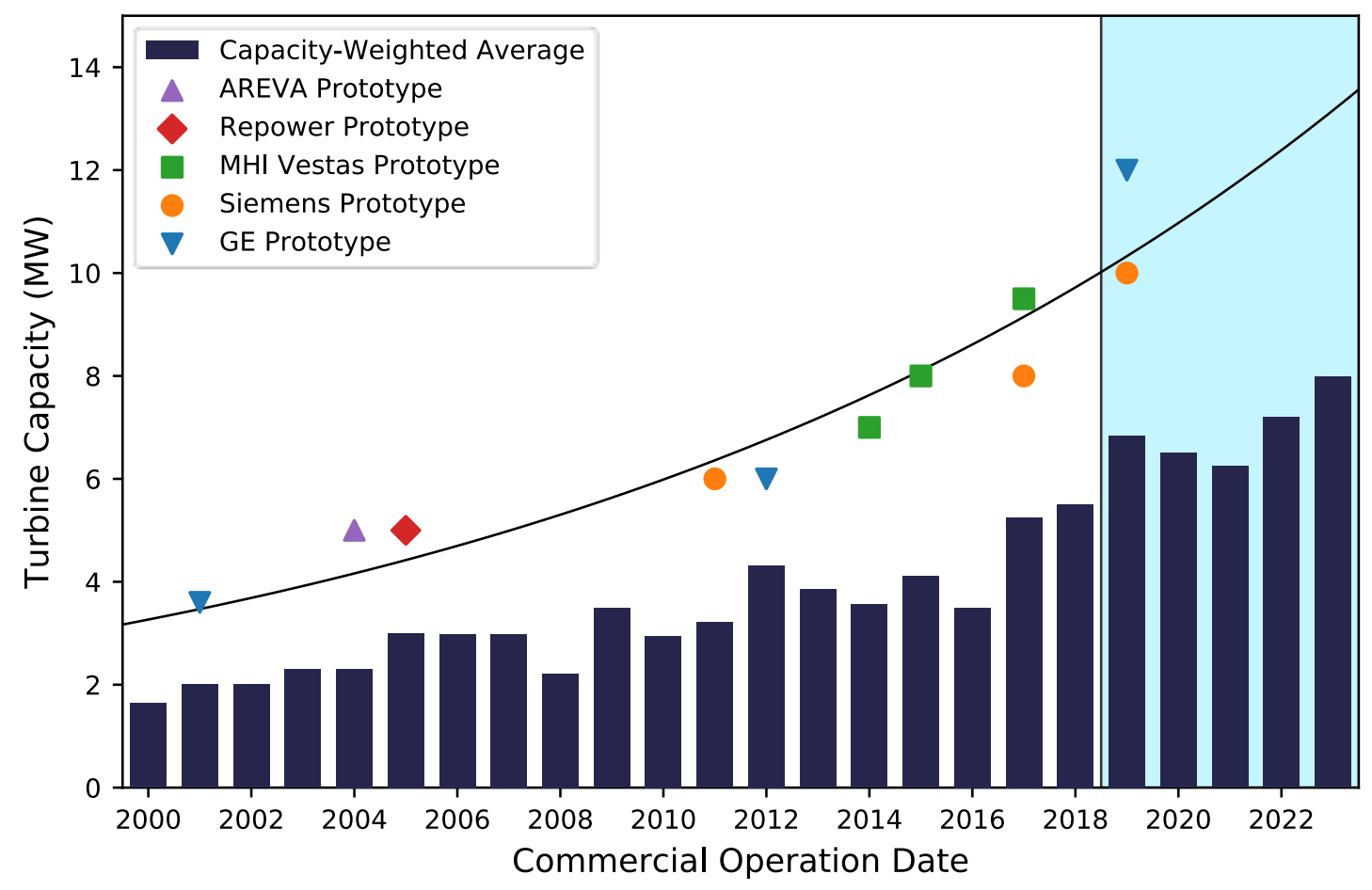

Figure 23. Average commercial offshore wind turbine rating compared to prototype deployment by year

Sources: Ragheb (2019), GE (2018), de Vries (2012), Composites World (2014), Adwen GmbH (2019), ${ }^{49}$ Power Engineering (2005), ${ }^{50}$ 4C Offshore (2017), Siemens (2013, 2019), Dvorak (2017)

From analysis of press releases, it takes at least 3 years for a turbine manufacturer to go from the first prototype to commercial production (GE 2018a; Siemens 2019). Historically, in many cases, this process is longer. Figure 23 shows that although offshore wind industry turbine size is indeed increasing, the maximum size of wind turbines that will be installed in later years is much larger than the weighted averages, and in 2018 there is no sign that offshore wind turbine growth is slowing down in spite of multiple logistical and infrastructure challenges. As shown, prototype capacity (shown in the colored symbols) has been consistently above the capacity of the weighted average turbine being installed.

\subsubsection{Typhoons and Earthquakes}

Offshore wind turbines are beginning to see more geographic diversity, especially as developers enter Asian markets wherein typhoons can bring extreme wave heights and wind speeds that exceed design specifications. Class $1 \mathrm{~A}$ wind turbines are already designed to withstand wind gusts up to 70 meters per second $(\mathrm{m} / \mathrm{s})(156$ miles per hour) but in these Asia-Pacific regions (and later in southern latitudes of the United States), the probability of major tropical cyclones (hurricanes) that produce loads exceeding the present design limits (set by International Electrotechnical Commission [IEC] standards) becomes more likely. Specialized hurricaneresilient designs are being developed to ensure that turbines, towers, blades, and substructures can withstand these extreme weather events.

\footnotetext{
${ }^{49}$ Note that AREVA is now a wholly owned subsidiary of Siemens Gamesa.

${ }^{50}$ Note that Repower now goes by the name Senvion.
} 
Offshore wind turbines are currently designed using IEC 61400-01 and IEC 61400-03 standards, which define a 3-second maximum gust condition of $70 \mathrm{~m} / \mathrm{s}$ (156 miles per hour) (IEC 2019a; 2019b). Oil and gas standards have been applied in the United States to manage the design of substructures. The recently released 2019 edition of IEC 61400-01 and 61400-03-1, the primary design standards for wind turbines, just added provisions for a wind turbine typhoon class. Both Siemens Gamesa and MHI Vestas have begun to ruggedize their turbine designs to adapt them to hurricane loading and comply with a more rigorous certification process to upgrade for the local conditions, particularly as they try and enter the Taiwan offshore wind market (Hill 2018). In some of these new offshore wind regions, there is also an increased threat of earthquakes; therefore, enhanced engineering activity to achieve seismic resilience has also been initiated.

\subsubsection{Offshore Wind Turbine Manufacturers}

Figure 24 shows the market share of each offshore turbine manufacturer for the cumulative installed capacity up to 2018, as well as the expected installations that have disclosed their intended turbine partner for near-term pipeline projects. After their merger, Siemens Gamesa continues to be the largest global supplier of offshore wind turbines, representing approximately $55 \%$ of installed capacity, or $12.3 \mathrm{GW}$, operating today. Siemens Gamesa is followed by MHI Vestas, with just over $15 \%$ market share.

The right side of Figure 24 shows the OEM suppliers selected by developers for projects in the pipeline that have announced their turbine. The chart shows Siemens Gamesa's share of projected total global capacity is likely to grow to $60.3 \%$ for new projects, whereas MHI Vestas is expected to hold on to about $14.5 \%$ total installed capacity. In addition, GE's share of total installed capacity is projected to grow to $8.9 \%$. Other OEMs showing increased market share include Goldwind and Ming Yang, companies that are building strength in the emerging Chinese market.

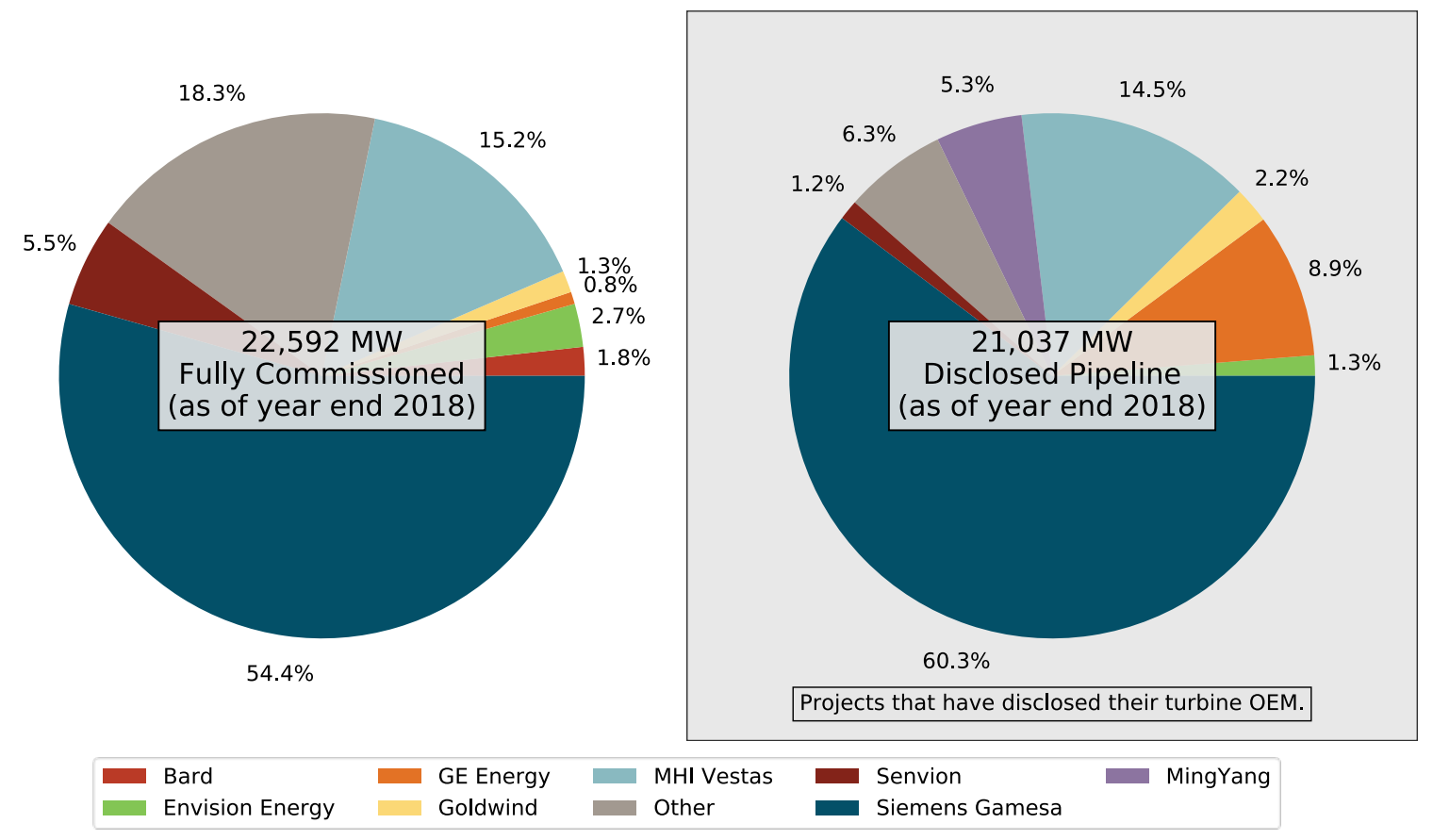

Figure 24. Offshore wind turbine manufacturers by market share for 2018 (left) and future (right) 


\subsection{Fixed-Bottom Substructures}

Figure 25 shows the current mix of substructure types for fixed-bottom foundation projects operating at the end of 2018 along with the expected makeup of substructure types for the 37,203 MW of projects in the pipeline that have announced their intended substructure. In 2018, monopiles continued to dominate the operating fleet of global offshore wind turbines, representing $73.5 \%$ of the total market. Alternative substructure types, such as gravity-base, jacket, tripod, and floating foundations, each represent about $5 \%$ of the historical market share.
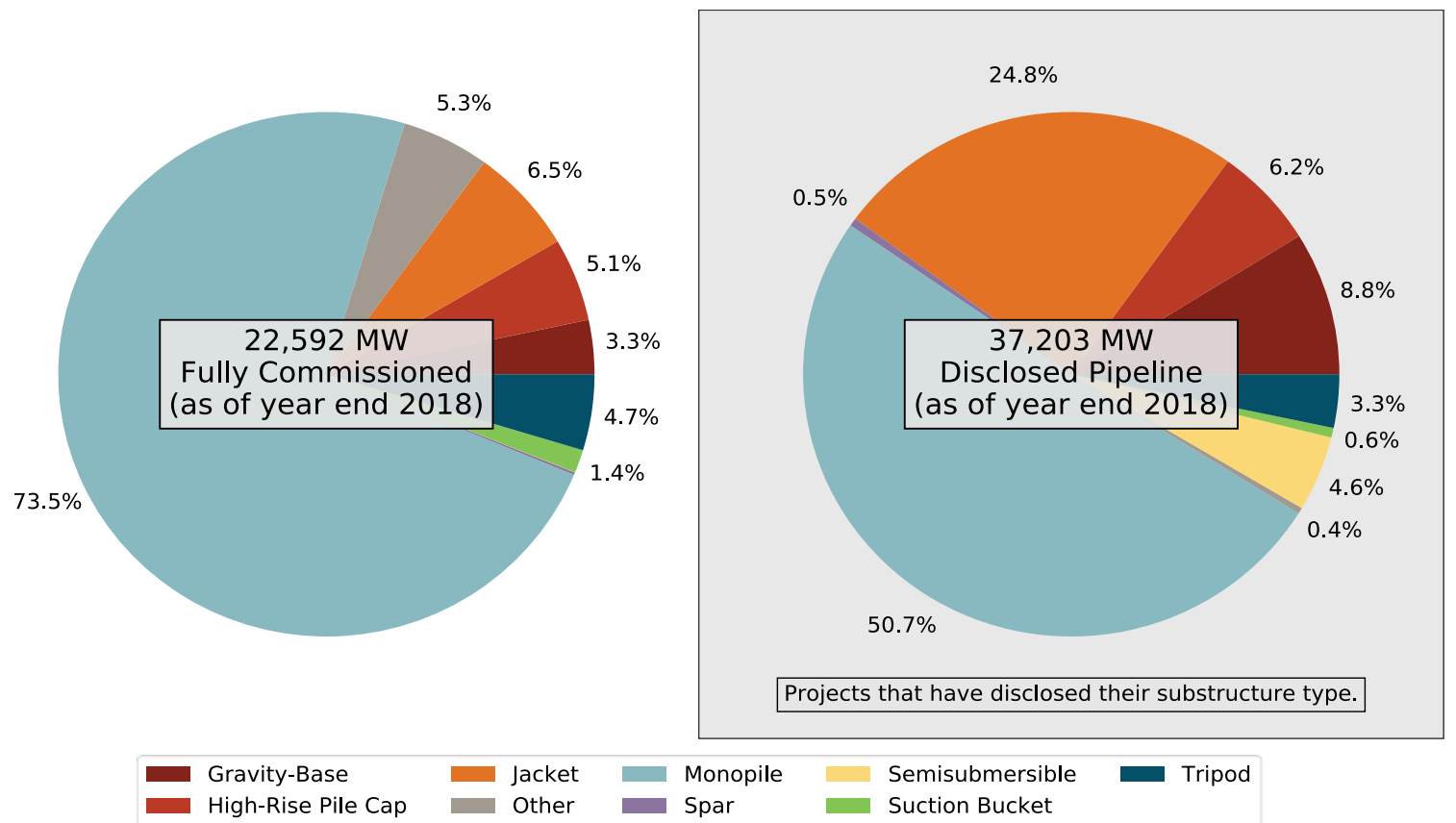

Figure 25. Offshore wind substructure technology trends in $2018^{51}$

Looking into the future, on the right side of Figure 25, developers have indicated they plan to increase the use of jackets by roughly fourfold. This change corresponds to projects being developed in deeper water depths and increased manufacturing options for jackets. Gravity-base foundations are also slowly increasing their market penetration because they do not require pile driving during installation, which eliminates underwater noise and potential negative impacts to marine mammals. Floating foundations are required for projects in water deeper than approximately $60 \mathrm{~m}$ and are discussed later in the report.

\subsection{Electrical and Power System Technology}

\subsubsection{Array Cables and Substations}

Buried, insulated, three-core copper cables are typically used for subsea array collector systems. Occasionally, aluminum cables are used as well. The array cables ${ }^{52}$ are designed to meet the requirements on physical strength, flexibility, and temperature characteristics of the offshore site. Array cables also incorporate fiberoptic cables, plant control, and communications. Power conductor sizes for array cables are selected based on

\footnotetext{
${ }^{51}$ High-rise pile caps are offshore wind foundations that use a group of piles to support a flat, stable pad. The wind turbine tower is then installed on top of the pad. These foundations are primarily found in the Chinese market and deployed in shallow waters.

${ }^{52}$ Array cables are electrical cables that connect individual turbines to each other and an offshore substation or transmission cable.
} 
their current carrying capacity and location in a string of turbines. Array cable cross sections at the end of the string can be as small as $150 \mathrm{~mm}^{2}$, and cables close to the substation can be $800 \mathrm{~mm}^{2}$ or larger.

As shown in Figure 26, 42\% of new intra-array cables energized in 2018 were supplied by Nexans, whereas JDR Cable Systems supplied $32.1 \%$ and Prysmian supplied $16.1 \%$. These shares were calculated by counting the number of grid-connected turbines in each wind power plant during 2018 (WindEurope 2019).

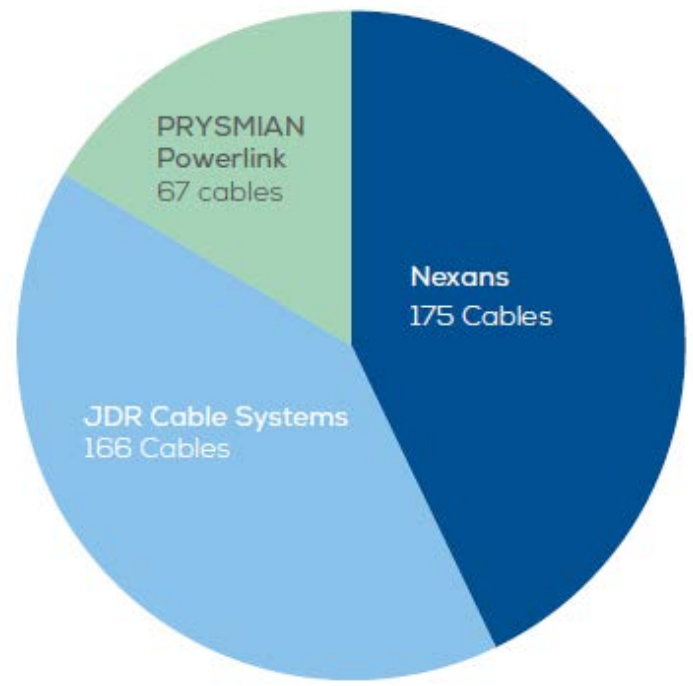

Figure 26. Number of turbines energized by supplier in 2018. Chart courtesy of WindEurope 2019

With the commissioning of the Aberdeen Bay offshore wind power plant in 2018, Nexans has now supplied two new offshore wind plants with its new 66-kilovolt $(\mathrm{kV})$ cable technology (Nissum Brending Vind in Denmark and Aberdeen Bay in the United Kingdom). As rated power capacity of offshore wind turbines continues to grow, project developers and operators are increasing use of $66-\mathrm{kV}$ cable technology instead of the conventional $33 \mathrm{kV}$. In 2018, there were three projects that used 66-kV array cables versus only one project in 2017. Operation at a higher voltage offers important life cycle cost-efficiency benefits, such as the possibility of reducing the number of offshore substations, decreasing the overall length of installed cables, and minimizing electric losses (Nexans 2018). During 2018, the advantages of 66-kV technology have been demonstrated by Nexans in three pilot projects: the Blyth Offshore Demonstrator (United Kingdom), Nissum Bredning Vind (Denmark), and Aberdeen Bay (United Kingdom) wind power plants. All these projects are currently connected to the grid and generating power. Nexans has also supplied a range of products and accessories including 66-kV sea cables (array and export cables), power cable accessories (e.g., equipment bushings, connectors, coupling connectors, surge arresters, dead-end receptacles, junction cabinets), GPH connection technology, and preassembled cables (Nexans 2018).

Continued development of several offshore projects in Southeast Asia has created new market opportunities for the undersea cable industry. For example, Formosa 1 is an offshore wind power plant being developed near Miaoli, Taiwan, by Formosa Wind Power Co in partnership with Macquarie Capital Group Limited, Ørsted, and Swancor Renewable. The 130-MW wind power plant will be Taiwan's first commercial-scale offshore wind project (Power Technology 2018). In 2018, JDR Cable Systems delivered $21 \mathrm{~km}$ of interarray cable, 13 $\mathrm{km}$ of export cable, and an additional $16 \mathrm{~km}$ of land cable to transmit power from the shore to the local substation. The 33-kV cables were manufactured at JDR's facility in Hartlepool, United Kingdom, before being shipped to Taiwan for installation by Jan De Nul. The project is targeted for completion in 2019 (JDR 2019). 


\subsubsection{Export and Land-Based Interconnect}

The electrical grid connection contributes significantly to the cost of an offshore wind power plant. It includes both offshore and land-based infrastructure and connects the wind power plant to the land-based electricity grid. AC offshore substations contain the common busbar for cable termination, protection, and switchgear, transformers that step up the voltage from a $33-\mathrm{kV}$ or $66-\mathrm{kV}$ array level to a $132-$ to $220-\mathrm{kV}$ export level, and reactive power compensation. There is normally more than one AC substation in a large wind power plant, thereby providing a higher level of reliability and redundancy in the electrical system to reduce the impact of a single point of failure. Similarly, DC offshore substations contain an AC busbar, protection, and switchgear; AC transformers; HVDC power electronic station; and DC terminals.

Typically, the AC export cables use conductor cores ranging from $600 \mathrm{~mm}^{2}$ to $1,200 \mathrm{~mm}^{2}$, although larger cross sections are possible. Various types of armoring can be used depending on seabed conditions, amount of vessel traffic, and water depth.

In terms of export cables in 2018, eight export cables manufactured by NKT Group were energized, representing 53.3\% of the annual market. Prysmian, Ls Cable \& System, and JDR Cable Systems each had about a 13.3\% share, and Nexans represented the remaining 6.7\%, as shown in Figure 27 (WindEurope 2019). When calculating these shares in Germany, the export cables are considered to be the cables connecting the offshore wind power plants to the land-based grid, whereas in other countries the export cables are considered to be the high-voltage, alternating-current cables only. Note that these market shares were calculated by considering only the export cables in operating wind power plants.

According to Market Research Consulting, the global submarine cable market accounted for $\$ 6.31$ billion in 2017 and is expected to reach $\$ 25.56$ billion per year by 2026 (Market Research Consulting 2018). Such growth is expected because of rising demand in both offshore wind and oil and gas operations. Increasing demand for HVDC submarine power cables is also one of the major electrical supply chain trends for offshore wind observed during the forecast period. By geography, several regions in Europe are dominating the offshore power cable market because of rapid growth in numbers of offshore wind projects and rising demand for intercountry submarine power transmission links. Some key players in the submarine power cable market include Furukawa Electric, General Cable Corporation, Hengtong Group, Hydro Group, KEI Industries, LS Cable \& System, Nexans, NKT Holding, Prysmian Group, Sumitomo Electric Industries, Tele-Fonika Kable S.A, ZTT International Limited, and TE Subcom.

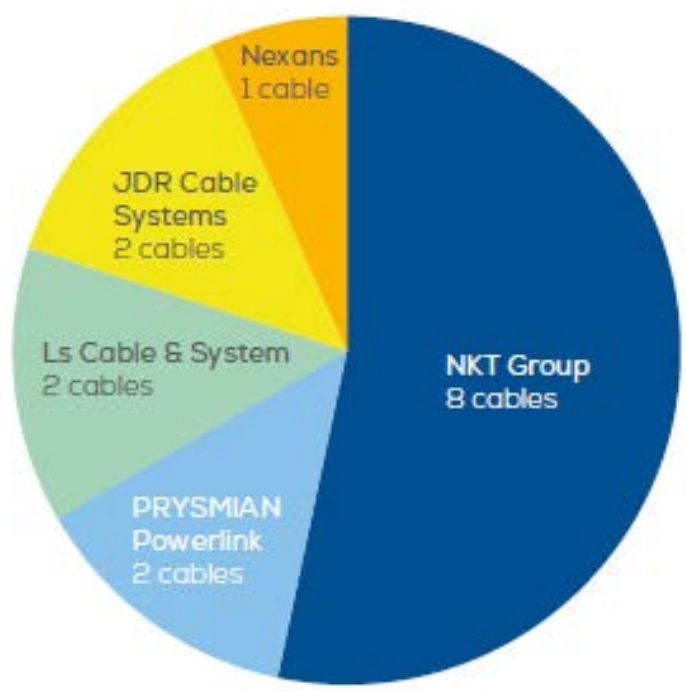

Figure 27. Share of energized export cables by supplier in 2018. Chart courtesy of WindEurope 2019 


\subsubsection{Transmission, Grid Integration, and Storage}

As the role of wind energy grows in the U.S. power grid, there is increased interest and requirement for it to provide essential reliability services. These services are critical to maintaining the reliability and stability of the grid, and historically were provided by large synchronous generators, mainly from fossil-fueled and hydroelectric generators (Denholm, Sun, and Mai 2019).

In 2018 and early 2019, as state offshore wind policy commitments grew from near $5 \mathrm{GW}$ to $20 \mathrm{GW}$ by 2035 , the challenge of integrating this amount of electricity into the existing land-based grid has begun to resonate as a high priority among the many developers, utilities, and state energy organizations (Business Network for Offshore Wind 2019). For some states like Massachusetts, New York, and New Jersey, injecting this amount of offshore wind represents up to $30 \%$ of their current electricity supply, which is likely to have significant impacts to the land-based grid and transmission system that have not been fully quantified. In the next year, the topic of offshore wind grid integration and grid planning is likely to gain more attention.

In most of today's power systems, wind (both offshore and on land) and solar generation still have a limited impact on grid operation because other generation sources can be dispatched. As the share of variable renewable generation becomes a major fraction of the total generation, electricity systems will need more flexibility services that can be potentially provided by the rapid response capabilities of electricity storage. The shift toward large-scale integration of energy storage into the power systems operation will need to be part of the energy planning process.

In 2018, Masdar and the Norwegian company Equinor (formerly Statoil) installed, and started testing, a new battery system designed to store electricity generated by the 30-MW Hywind Scotland, the world's first commercial-scale floating wind power plant. This battery energy storage system (BESS) project coupled with the offshore wind power plant is the first of its kind in the world. The goal of the project is to evaluate the capabilities of advanced storage technologies to optimize the release of electricity from renewable energy plants to transmission grids - from both a technical and commercial perspective. A conceptual diagram of interconnection between the offshore wind power plant located at a short distance from the shore and the landbased BESS is shown in Figure 28 (Equinor 2018b).

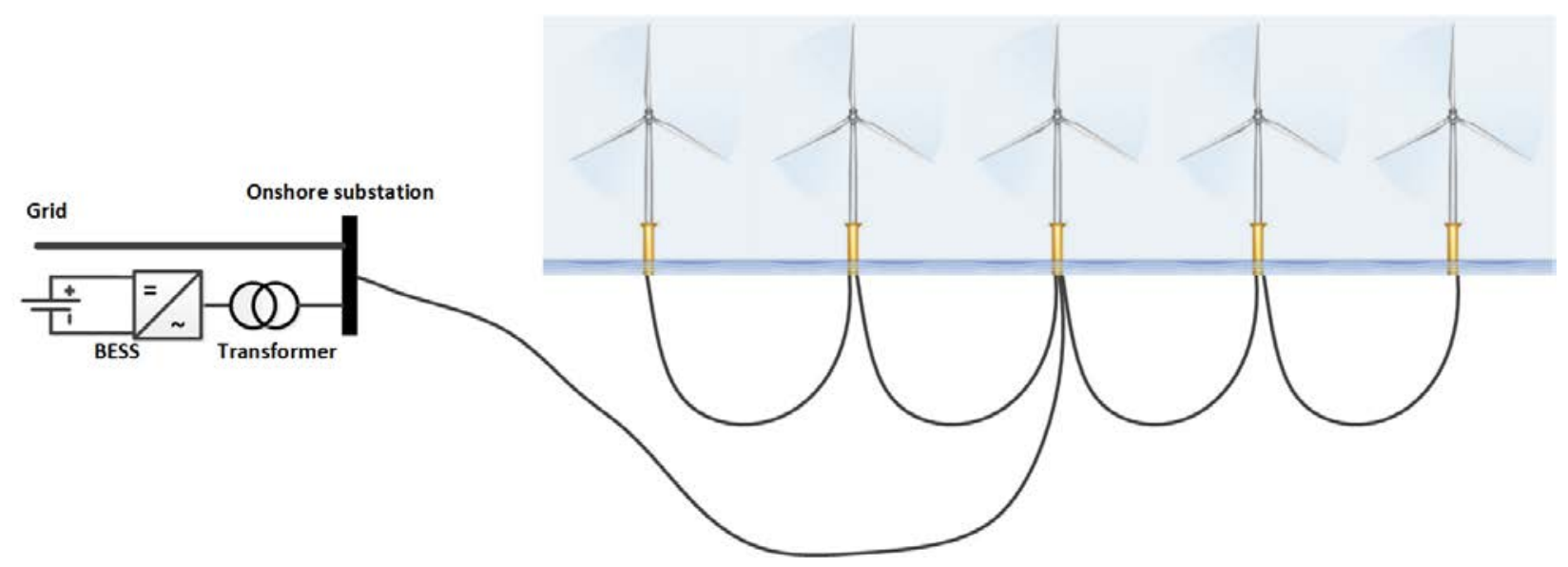

Figure 28. Near-shore offshore wind power plant operating with the land-based BESS. Illustration by NREL

The BESS technologies can provide a wide range of utility-controlled and self-directed services (Benson 2018).

\subsection{Floating Technology Trends}

Floating wind energy technology is advancing rapidly. Based on the resource capacity, the prospect for significant future deployment potential of floating wind seems similar to fixed-bottom wind but there are many 
technology challenges that must still be solved. Some of these unique technology challenges for floating wind are discussed in this section.

\subsubsection{Floating Wind Turbines}

Like fixed-bottom technology, developers of floating offshore wind projects generally want to use the largest commercial offshore turbines available on the market. For example, WindFloat Atlantic in Portugal is planning to install three MHI Vestas V164-8.4 MW turbines, and the Kincardine project in Scotland is installing five MHI Vestas V164-9.5 MW turbines (Froese 2018; 4C Offshore 2019; Davidson and Weston 2018). The motivation is the same for both floating and fixed-bottom foundations: project costs are lower with larger turbines. To date, all offshore wind turbines used in floating applications have been designed for fixed-bottom applications. Therefore, the market information for turbines on fixed-bottom foundations applies directly to floating systems. Floating-specific turbines have not yet been designed but conceptual engineering studies suggest a greater value proposition for lightweight turbine components, which may help reduce overall system weight. Because the floating wind pipeline is still small, the demand for these floating-specific offshore wind turbines is not high enough for OEMs to take the turbine development risk. More certainty in a large future floating wind market will be needed to motivate the first generation of customized floating wind turbines.

\subsubsection{Floating Support Structures}

The cost of a floating offshore wind project depends on the characteristics of the support structure it uses. The cost of the support structure itself is important, but so is the support structure's ability to help lower costs in other parts of the system, such as by enabling serial fabrication, inshore assembly, and commissioning, and by minimizing expensive offshore labor, including O\&M. In addition, the coupled hydrodynamic-aerodynamic design of the floating system is the primary method for protecting the turbine from excessive loads and accelerations, especially under extreme conditions. Most floating projects in the pipeline plan to use semisubmersible substructures (see Table 11) because inherently, semisubmersible floating foundations have a shallow draft and are stable even after the turbine is installed. This allows for a full assembly and commissioning at quayside, and allows the full system to be towed from an inshore assembly port to an offshore station without the use of heavy-lift installation vessels.

Figure 29 shows a capacity-weighted average of the substructure choices for all floating projects in the NREL OWDB at the end of 2018.

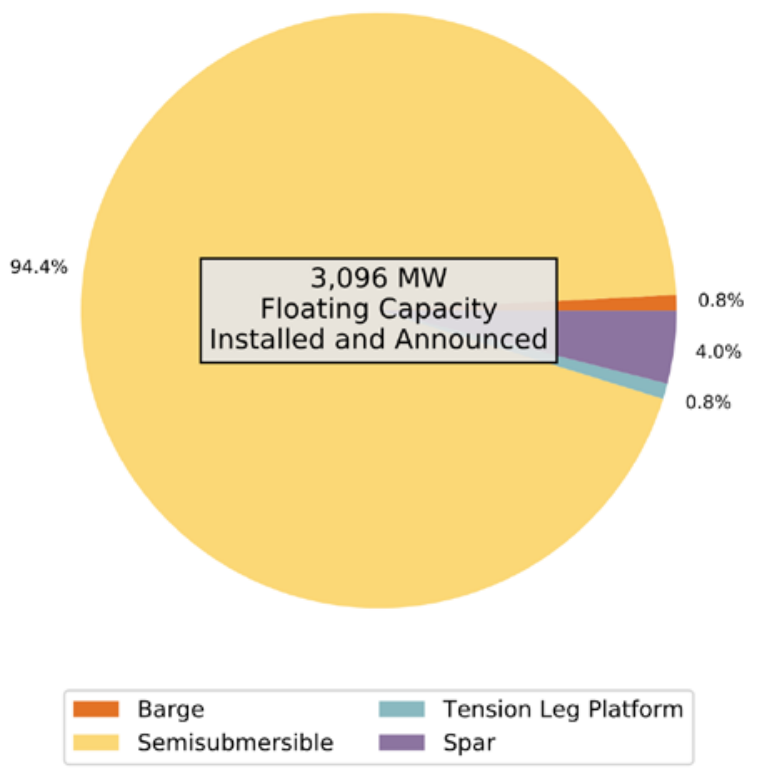

Figure 29. Capacity-weighted average of floating substructure selection for the global pipeline 
The chart shows that $94 \%$ of projects in the floating wind pipeline plan to use semisubmersible substructures. Approximately 4\% use or plan to use spar technology, like the substructures deployed by Equinor on the first commercial floating wind project, shown in Figure 30 (Equinor 2018a). The remaining substructures are tension leg platforms and barges.

As the industry deploys the next generation (second generation) of technology, new hybrid floating platform design concepts are being introduced that have desirable characteristics like the semisubmersible. In 2018, Stiesdal Offshore Technologies introduced the TetraSpar floater, which has a stable buoyant floating substructure with low draft to allow for inshore assembly but uses a flexible cable system to deploy a ballast weight at sea. The design incorporates a tubular steel base with a suspended underwater tetrahedral counterbalance. Innogy and Shell have partnered with Stiesdal to build a single turbine demonstration project in Norway that plans to use a 3.6-MW Siemens Gamesa turbine (Weston 2019). In November 2016, SBM Offshore won a contract to deliver three floating platforms for the 24-MW Provence Grand Large pilot wind energy project in the French Mediterranean. The SBM tension leg platform substructure design is unique because it is stable before attaching the mooring lines - an uncommon characteristic and one of the major drawbacks of conventional tension leg platforms. Both the TetraSpar and the SBM tension leg platform represent hybrid platform technologies that could challenge conventional semisubmersible technology for cost competitiveness and possible future market share. Figure 31 shows both designs.

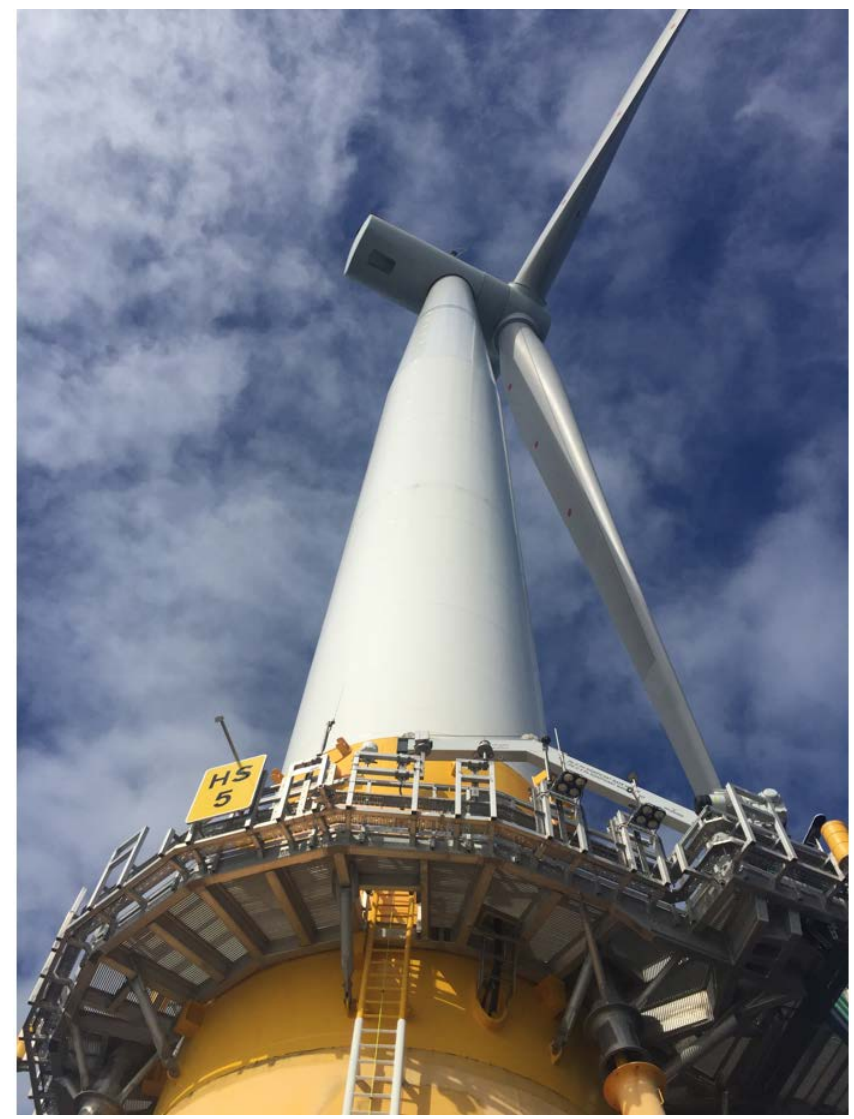

Figure 30. A 6-MW floating wind turbine in Equinor's 30-MW array near Peterhead, Scotland, supported by a spar buoy floating platform. Photo courtesy of Walt Musial, NREL 

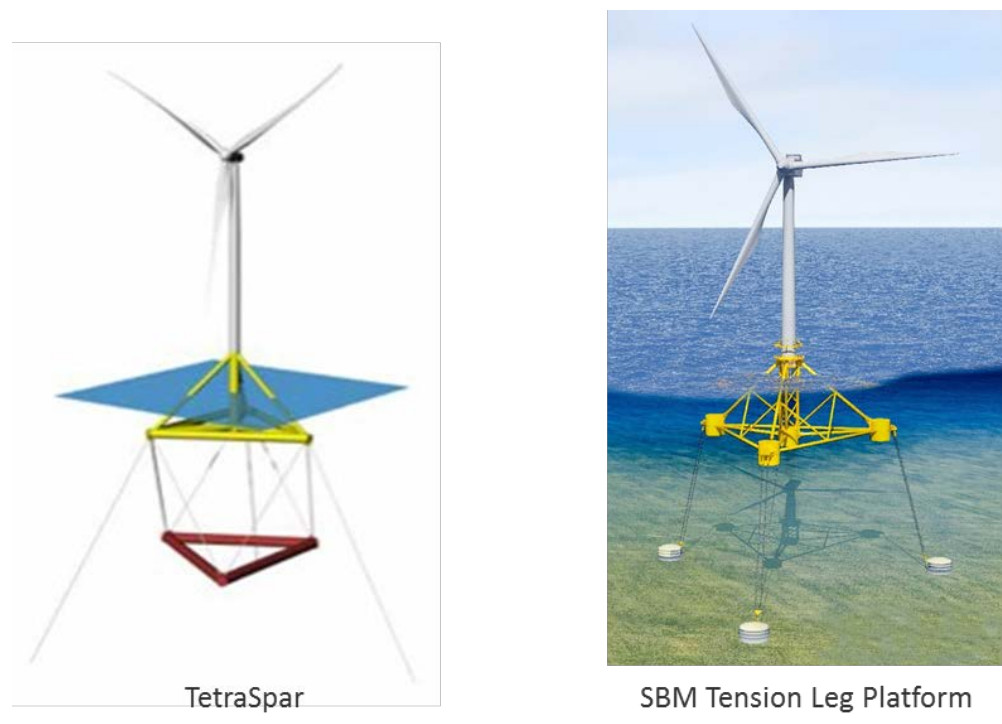

Figure 31. Second-generation floating wind concepts of alternative hybrid substructures. Images courtesy of Stiesdal Offshore Technologies (left) and SBM Offshore (right)

One concern for floating projects in the United States and likely other parts of the world is the design of mooring systems for the depth characteristics of the U.S. Outer Continental Shelf. In the eastern United States, it is likely that floating technology could open large areas in the 60-100-m depth range for offshore wind development. Although this water depth is deep by fixed-bottom wind turbine standards, for floating, these depths are shallower than typical floating oil and gas rigs and are generally unique to offshore wind. Shallow water means shorter mooring lines, which act as shock absorbers to absorb hydrodynamic loading. If they are not long enough or heavy enough, platform loads could increase. New mooring system designs are needed to enable floating technology at shallow water depths. New designs are emerging already to allow projects to be sited in these water depths (4C Offshore 2019b). Conversely, because of the steep shelf on the Pacific Coast, floating projects will be located at sites with water depths up to $1,000 \mathrm{~m}$ or more. In these waters, the optimization of deeper water moorings is a different technology challenge because project developers are likely to be encouraged to reduce the footprint of their anchor circle and generally shorten the length of their mooring lines to minimize the impact to other users of the sea. In 2018, DOE and NYSERDA formed the National Offshore Wind R\&D Consortium to address technical issues affecting developers in the United States and released a solicitation calling for engineering solutions to shallow and deep-water mooring design issues (NYSERDA 2019).

\subsubsection{Electrical Power Systems}

Floating turbines allow greater distances from shore, which can have several impacts on cost including the design of subsea electrical cabling and system configuration (e.g., consideration of HVDC) as well as logistical challenges during the project's construction and operation phases (e.g., transport time, effective length of working day).

Floating offshore wind platforms are constantly moving with the waves and winds acting on the structure. As a result, the attachment point for the electric cable is in motion as well. For a fixed-bottom foundation, this attachment point is firmly secured. The dynamic nature of floating platforms will require developers and cable manufacturers to develop dynamic cable designs to ensure that cyclic loads and bends on the cable will not compromise the system. This approach is important for turbine systems as well as possible floating substations. In March 2019, Prysmian announced that it had developed a specialized submarine cable system specifically designed for floating offshore wind applications. The company plans to test their new cable on the 24-MW Provence Grand Large Demonstration in France (T\&D World 2019). 
JDR, a supplier of subsea power cables and umbilical cables to the global offshore energy industry, has been selected by WindPlus as the preferred cable supplier for the Windfloat Atlantic 25-MW floating wind power plant. The project—located off the coast of Viana de Castelo, Northern Portugal — will be the industry's first application of dynamic cables operating at $66 \mathrm{kV}$ with V164 floating wind turbine generators (WireTech 2019).

In April 2019, the Carbon Trust announced the five winners of its dynamic export cable competition as a part of the Floating Wind Joint Industry Project, which aims to accelerate and support the development of commercial-scale floating wind power plants. The project is a collaboration between industry partners EnBW, ENGIE, Eolfi, E.ON, Equinor, Innogy, Kyuden Mirai Energy, Ørsted, ScottishPower Renewables, Shell, Vattenfall, and Wpd, with support from the Scottish government (Carbon Trust 2019).

\subsubsection{Targeted Research in the United States}

The U.S. offshore wind industry is poised for substantial deployment of over $10 \mathrm{GW}$ of electric-generating capacity over the next decade, but with only $30 \mathrm{MW}$ operating there is some uncertainty about the transfer of largely European-based technology to the United States. The physical and economic characteristics of U.S. sites, supply chains, and offshore resources may present unique issues that would require additional research conducted outside the scope of individual commercial projects. To help address this concern, a new national technical research consortium was formed in 2018 with the purpose of conducting new technology research to benefit the end users (developers) of the U.S. market. Under an open funding opportunity, DOE committed \$20.5 million in 2018 to NYSERDA to form a National Offshore Wind R\&D Consortium. The corporation agreed to match the DOE contribution and launched a funding organization to make research and development awards on prioritized topics that will support developers in achieving their near-term deployment and cost targets. The first solicitation was released by NYSERDA on March 29, 2019, and the first awards are expected in 2019. As the organization matures, NYSERDA envisions that the consortium will become a nonprofit entity with a self-sustaining mission that extends well beyond the initial 4-year time frame (NYSERDA 2019). 


\section{Cost and Pricing Trends}

The PPA and price schedule agreed upon between Vineyard Wind LLC and Massachusetts electric distribution companies in July 2018 offers the first market-based reference point for the price and cost of commercial-scale $(800 \mathrm{MW})$ offshore wind generation in the United States. It suggests that the Vineyard Wind project off Massachusetts falls within the price range of European offshore wind projects, with an expected start of commercial operation between 2022 and 2023. This PPA was established against the backdrop of continued price and commensurate cost reductions in major offshore wind markets from 2016 to 2018. Section 5.1 provides a discussion of price trends for fixed-bottom projects, including an analysis of the PPA price point for the Vineyard Wind project. Section 5.2 summarizes LCOE trends for fixed-bottom projects, with subsections on the constituent parts of LCOE (i.e., CapEx [Section 5.2.2], turbine costs [Section 5.2.3], operational expenditures (OpEx) [Section 5.2.4], and financing [Section 5.2.5]. Section 5.3 summarizes cost trends for floating technology.

\subsection{Fixed-Bottom Pricing Trends}

Figure 32 shows (adjusted) strike prices from recent offshore wind auctions held in Germany, the United Kingdom, the Netherlands, Denmark, and the United States, for projects to be commissioned between 2017 and 2025 .

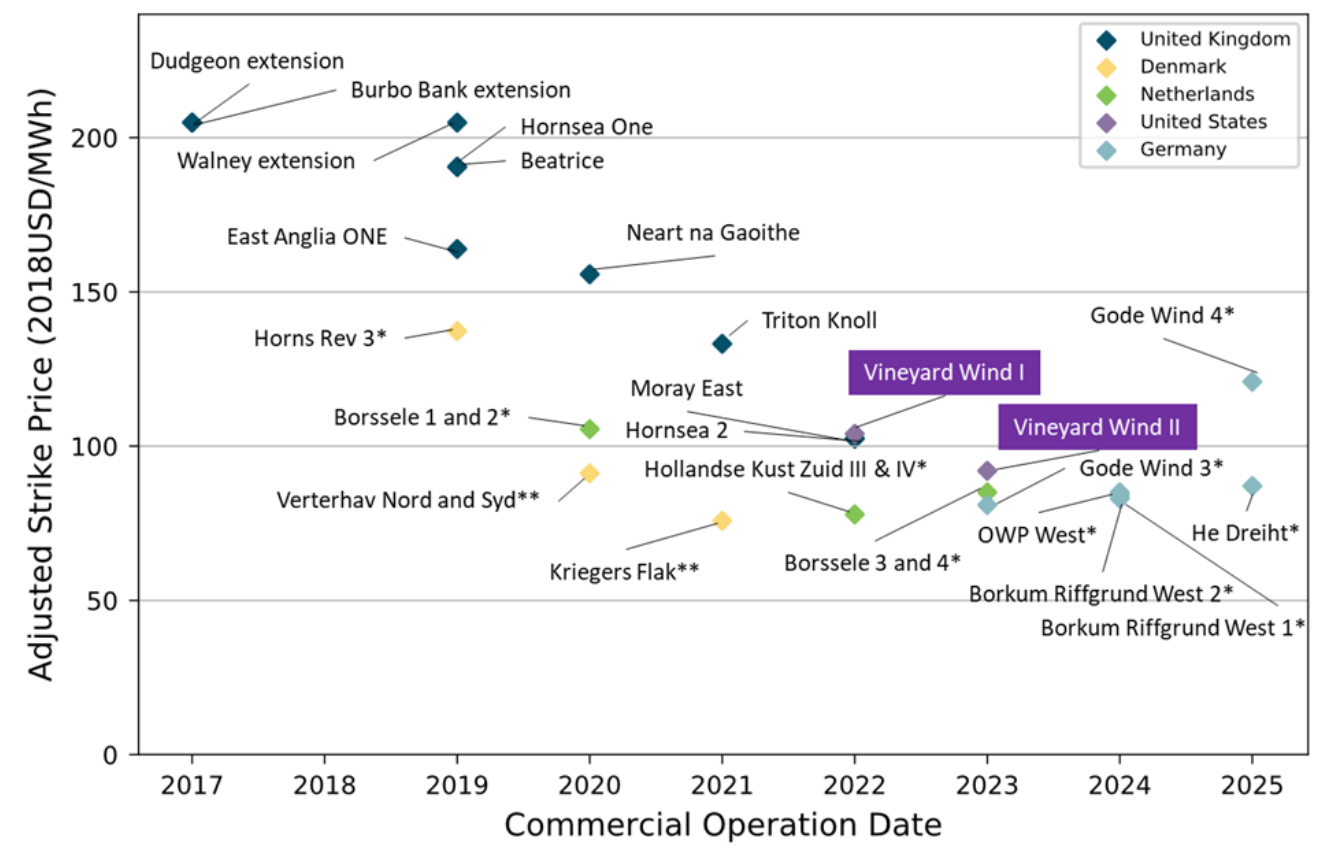

Figure 32. Adjusted strike prices from U.S. and European offshore wind auctions. Reprinted from Beiter et al. (2019)

Notes: *Grid and development costs added; **Grid costs added and contract length adjusted; includes data for commercial-scale projects only

The winning auction prices (commonly referred to as "strike prices") 53 that are shown in the figure were adjusted by NREL for contract length, grid connection, and revenue mechanism for an "all-in" price

\footnotetext{
${ }^{53}$ The strike price for an offshore wind project from an auction is usually the lowest bid price at which the offering can be sold. The strike price usually covers a specific contract term for which the project will be paid for the energy (and possibly other products or attributes) produced. The offeror of that strike price is awarded the rights to develop a particular parcel under predetermined conditions set in the tender offer that may vary by country or market. The strike price should not be confused with levelized cost of energy, which may be calculated using different financing and cost assumptions.
} 
comparison (see Musial et al. 2017 for a more detailed description). ${ }^{54}$ These adjustments were made to account for differences in project scope. For example, under German award terms, the project developer is only responsible for expenditures related to intra-array cabling and the offshore substation but not for the rest of the export cable system. Adjustments were made to the German projects to add the expected cost of the export cable and land-based grid connection back into the price.

The data suggest a trend of declining price levels from approximately \$200/MWh (2017-2019 COD) to approximately $\$ 75 / \mathrm{MWh}$ for projects with a 2024-2025 COD. ${ }^{55}$ These reductions in the prices for procuring offshore-wind-produced electricity were achieved through a combination of favorable siting characteristics; increased project size; continued optimization of technology and installation processes; improved market, regulatory, and auction design structures; increased competition within the supply chain; favorable macroeconomic trends; and strategic market behavior.

\subsubsection{Vineyard Wind PPA (Lease OCS-A-0501) Analysis}

On July 31, 2018, Vineyard Wind LLC and the Massachusetts electric distribution companies submitted a 20year PPA for $800 \mathrm{MW}$ of offshore wind generation and renewable energy certificates to the Massachusetts Department of Public Utilities for review and approval. The Vineyard Wind/Massachusetts PPA established a contract for procurement of electricity from two 400-MW facilities that enter commercial operation in 2022 (facility 1$)^{56}$ and 2023 (facility 2), respectively, at a specified pricing schedule (Massachusetts Department of Public Utilities 2018a, 2018b). Key contractual terms and project filings from the Vineyard Wind LLC Draft Environmental Impact Assessment (Vineyard Wind 2018a), construction and operations plan (Vineyard Wind 2018b), and the independent evaluator report (Peregrine Energy 2018) are shown in Table 12.

The documented first-year price for delivery of offshore wind generation and renewable energy certificates under the Vineyard Wind/Massachusetts PPA is \$74/MWh (2022\$) for facility 1 (400 MW) and \$65/MWh $(2023 \$)$ for facility $2(400 \mathrm{MW})$, but these prices do not reflect all of the revenue that the project will generate, and are therefore lower than the data shown in Figure 32. To allow for a more accurate comparison with the adjusted European auction prices, Beiter et al. (2019) calculated a levelized PPA price, accounted for revenue streams outside of the PPA, ${ }^{57}$ and excluded U.S. tax benefits (i.e., election of the investment tax credit [ITC]). The resulting (adjusted) PPA price was estimated to be $\$ 98 / \mathrm{MWh}(2018 \$$ ).

Although this (adjusted) "all-in" price level of $\$ 98 / \mathrm{MWh}$ is significantly higher than the reported first-year PPA prices, the data in Figure 32 show that the project costs are in line with European project bids for the same time frame. This suggests that the generally anticipated price (and cost) premium for the nascent U.S. offshore wind industry in comparison to offshore wind projects in the established European markets might be much less pronounced than has widely been expected by many analysts. Earlier cost analyses estimated LCOE between \$120/MWh and \$160/MWh for a commercial-scale offshore wind project built in the northeastern United States in the early 2020s (see e.g., Beiter et al. 2017; Musial et al. 2016; Maness et al. 2017; Kempton et al. 2016).

\footnotetext{
${ }^{54}$ In general, these adjusted costs are higher than the unadjusted strike prices but still reflect a steep decline in price for European offshore wind projects installed out to the 2025 COD.

${ }^{55}$ Note that many of the projects shown in Figure 32 with future CODs have not yet reached the financial investment decision, and some caution is appropriate when determining whether these projects will reach COD.

${ }_{56}$ Vineyard Wind LLC has recently reported its intent for both facilities to be in operation by the end of 2022, ahead of the commercial operation date indicated on initial fillings (Vineyard Wind 2018c).

${ }^{57}$ One of the revenue streams outside of the PPA considered is sales into the ISO-New England (ISO-NE) Forward Capacity Market. Note that in its capacity auction FCA \#13 held on February 4, 2018, Vineyard Wind did not qualify for the renewable technology resource exemption, which allows a resource to be exempt from the ISO-NE minimum-offer price rule. Vineyard Wind participated in the ISO-NE substitution auction and secured 54 MW of capacity. ISO-NE filed tariff changes on November 30, 2017, to allow offshore wind resources located in federal waters, including Vineyard Wind, to qualify for renewable technology resource treatment in future auctions. These tariff changes were approved by the Federal Energy Regulatory Commission on January 29, 2019 (ISO Newswire 2019).
} 
Table 12. Vineyard Wind LLC/EDC PPA Contract Terms ${ }^{58}$

\begin{tabular}{|c|c|c|c|c|}
\hline & PPA 1 & PPA 2 & Notes & Source \\
\hline Capacity [MW] & 400 & 400 & N/A & $a, b$ \\
\hline $\begin{array}{l}\text { Commercial operation } \\
\text { date }\end{array}$ & $\begin{array}{l}\text { January } 15 \\
2022\end{array}$ & $\begin{array}{l}\text { January } 15 \\
2023\end{array}$ & N/A & $a, b$ \\
\hline Delivered product & \multicolumn{2}{|c|}{$\begin{array}{l}\text { Energy and renewable energy } \\
\text { certificates }\end{array}$} & N/A & $a, b$ \\
\hline $\begin{array}{l}\text { First-year PPA price } \\
\text { [\$/MWh] }\end{array}$ & $74 \$ 2022 / \mathrm{MWh}$ & $65 \$ 2023 / \mathrm{MWh}$ & $\mathrm{N} / \mathrm{A}$ & $a, b$ \\
\hline PPA duration [years] & \multicolumn{2}{|c|}{20} & N/A & $a, b$ \\
\hline Escalation factor [\%] & \multicolumn{2}{|c|}{2.5} & N/A & $a, b$ \\
\hline \multicolumn{5}{|c|}{ Vineyard Wind LLC Project Filings } \\
\hline Wind speed $[\mathrm{m} / \mathrm{s}]$ & \multicolumn{2}{|c|}{9.3} & $\begin{array}{l}\text { Simple average of the entire Vineyard Wind } \\
\text { lease area }\end{array}$ & c \\
\hline Net capacity factor [\%] & \multicolumn{2}{|c|}{45} & $\begin{array}{l}\text { Average capacity factor reported by Vineyard } \\
\text { Wind; assumed to be net capacity factor }\end{array}$ & d \\
\hline Average water depth [m] & \multicolumn{2}{|c|}{42} & $\begin{array}{l}\text { The construction and operations plan indicates } \\
\text { water depths in the northern half of the lease } \\
\text { area range from } 35 \text { to } 49 \mathrm{~m} ; 42 \mathrm{~m} \text { is the } \\
\text { average }\end{array}$ & d \\
\hline Substructure type & \multicolumn{2}{|c|}{ Monopiles } & $\begin{array}{l}\text { Vineyard Wind has indicated that it prefers to } \\
\text { use monopiles but may deploy jackets for up to } \\
400 \mathrm{MW} \text { of capacity depending on seafloor } \\
\text { conditions }\end{array}$ & d \\
\hline Turbine rating $[\mathrm{MW}$ & \multicolumn{2}{|c|}{8} & Turbine rating will range between 8 and $10 \mathrm{MW}$ & $d$ \\
\hline Export cable length [km] & \multicolumn{2}{|c|}{69.2} & $\begin{array}{l}\text { Generator lead line proposal selected by buyer } \\
\text { (Vineyard Wind LLC procures all cables from } \\
\text { turbine to point of interconnection); point of } \\
\text { cable landfall: New Hampshire Avenue }\end{array}$ & e \\
\hline $\begin{array}{l}\text { Land-based cable } \\
\text { length }[\mathrm{km}]\end{array}$ & \multicolumn{2}{|c|}{9.65} & $\begin{array}{l}\text { Generator lead line proposal selected by buyer } \\
\text { (Vineyard Wind LLC procures all cables from } \\
\text { turbine to point of interconnection); } \\
\text { interconnection point: Barnstable }\end{array}$ & e \\
\hline O\&M port distance $[\mathrm{km}]$ & \multicolumn{2}{|c|}{60} & O\&M port: Vineyard Haven & $d$ \\
\hline $\begin{array}{l}\text { Installation port } \\
\text { distance }[\mathrm{km}]\end{array}$ & \multicolumn{2}{|c|}{92} & $\begin{array}{l}\text { Installation port: New Bedford Commerce } \\
\text { Terminal }\end{array}$ & d \\
\hline ITC [\%] & 18 & 18 & $\begin{array}{l}\text { Assumes safe harbor provision through } \\
\text { expense of } 5 \% \text { of the overall project cost by the } \\
\text { end of } 2018 \text { (facility 1) and } 2019 \text { (facility } 2 \text { ) }\end{array}$ & $f$ \\
\hline \multicolumn{5}{|c|}{$\begin{array}{l}\text { Source: Reprinted from Beiter et al. (2019) } \\
\text { a Massachusetts Department of Public Utilities (2018a) } \\
\text { b Massachusetts Department of Public Utilities (2018b) } \\
\text { c Musial et al. (2017) } \\
\text { d Vineyard Wind (2018b) } \\
\text { e Vineyard Wind (2018a) } \\
\text { f Peregrine Energy (2018) }\end{array}$} \\
\hline
\end{tabular}

\footnotetext{
${ }^{58}$ These terms are derived from the PPA contract between NSTAR Electric Company d/b/a Eversource Energy and Vineyard Wind LLC; similar contract terms apply to the other electric distribution companies that have separate contracts with Vineyard Wind LLC.
} 
The following is a set of factors that may help explain how Vineyard Wind may have been able to achieve lower-than-expected prices, which are on par with the European price reductions shown in Figure 32:

- The ability to import major technology components from Europe and Asia (e.g., nacelles, blades, cables)

- Favorable offtake conditions for electricity produced by offshore wind in the United States (e.g., relatively low merchant risk compared to the terms of recent European tenders)

- Use of state-of-the art technology solutions expected from early U.S. projects (e.g., Vineyard Wind LLC has announced its intent to procure the V164-9.5 MW turbine [MHI Vestas 2018])

- Project size of $800 \mathrm{MW}$ that is comparable to large European projects

- Developer's experience with installing and operating offshore wind plants globally

- Successful demonstration of offshore wind technology at the Block Island Wind Farm may have lowered some risk perceptions

- Strategic bidding by tender participants for entry into emerging U.S. market (e.g., to gain "first-mover" advantages)

- U.S. market pipeline visibility and growing state policies (see Section 2)

- Industry consolidation as evidenced by Deepwater Wind's acquisition by Ørsted in December 2018

- Intensified competition within the global and U.S. supply chain and among bidders.

This price signal from the Vineyard Wind/EDC PPA could be indicative of subsequent procurement prices of U.S. commercial-scale offshore wind generation in the 2020s. However, a combination of factors determines future price and cost levels (Musial et al. 2016). Massachusetts legislation H.4568 requires future offshore wind generation procured under its capacity mandate of $1,600 \mathrm{MW}^{59}$ to produce a price below the Vineyard Wind LLC/EDC PPA contract price. ${ }^{60}$ This will require additional cost reductions amid a tax environment that is expected to become less favorable with the ITC phase-out underway (see Section 5.2.6). It is also possible that the Vineyard Wind LLC/EDC PPA price could have benefited from one-time effects, such as strategic bidding behavior among market entrants to gain first-mover advantages for subsequent U.S. offshore wind tenders.

Beyond Vineyard Wind, there is only a limited number of price signals from U.S. projects but their project sizes are smaller than $250 \mathrm{MW}$. The prices for these small-to-medium size projects are shown in Section 2.4.

\subsubsection{European Auction Results and Outlook}

Major offshore wind auctions were held in Germany and the Netherlands during quarter 1 (Q1) and Q2 of 2018. Auction activity ceased during the second half of 2018. Table 13 lists the auctions held in European markets during 2018. These were described in greater detail in the 2017 Offshore Wind Technologies Market Update (Beiter et al. 2018), as they all took place in early 2018.

\footnotetext{
${ }^{59}$ Massachusetts legislation H.4568 mandates the procurement of $1.6 \mathrm{GW}$ of offshore wind capacity by 2027.

${ }^{60}$ The Massachusetts legislature is considering a change to this requirement, which would adjust the procurement price of the previous solicitation for the availability of federal tax credits, inflation, and incentives (amendment 280 to H.3800; H.3801).
} 
Table 13. Offshore Wind Auctions During 2018

\begin{tabular}{|c|c|c|c|c|c|c|}
\hline Project & Country & Auction & Award Date & $\begin{array}{c}\text { Capacity } \\
\text { (MW) }\end{array}$ & $\begin{array}{l}\text { Auction Price } \\
\text { (2016\$/MWh) }\end{array}$ & $\begin{array}{c}\text { Adjusted } \\
\text { Auction Price } \\
\text { Estimate } \\
(2016 \$ / M W h)\end{array}$ \\
\hline $\begin{array}{c}\text { Borkum Riffgrund } \\
\text { West } 1\end{array}$ & \multirow[t]{2}{*}{ Germany } & \multirow{2}{*}{$\begin{array}{l}\text { Second Auction } \\
\text { (§26 WindSeeG) }\end{array}$} & \multirow{2}{*}{$04 / 27 / 18$} & 420 & 0 & $\sim 79$ \\
\hline Gode Wind 4 & & & & 132 & 118 & $\sim 115$ \\
\hline $\begin{array}{l}\text { Hollandse Kust Zuid } \\
\text { III and IV }\end{array}$ & Netherlands & & 03/19/18 & 700 & 0 & $\sim 74$ \\
\hline
\end{tabular}

In Germany, no further auction activity is expected for a 3-year period after conclusion of the country's first two rounds of auctions held under the \$26 Offshore Wind Act (WindSeeG) during 2017-2018. Although the German coalition government signaled it may hold an extra tender, it has not formally proposed another auction round to date ahead of 2020 (Foxwell 2018a). Industry groups have requested to "advance grid expansion and optimization and reduce regulatory hurdles for sector coupling" (German Offshore Wind Energy Foundation 2019). After awarding Hollandse Kust Zuid I and II projects (700-750 MW) on March 19, 2018, in a zero-subsidy bid, no additional tender was conducted during 2018 in the Netherlands. Tenders for Hollandse Kust (zuid) wind farms III and IV (700 MW) are scheduled to be held in March 2019 with awarded projects expected to commercially operate by 2023. The United Kingdom will continue its tender activity with a third contract-for-difference allocation round ("AR3") in May 2019. The tender budget is specified at $£ 60$ million, with a delivery cap of $6 \mathrm{GW} .{ }^{61}$ The last award in the United Kingdom was made during its contractfor-difference 2 round in 2017 (“AR2"). After inactivity during 2018, Denmark has selected the location of a new offshore wind facility ( $800 \mathrm{MW}$ ) off Nissum Fjord to be auctioned during 2019 with a COD between 2024 and 2027.

\subsection{Fixed-Bottom Offshore Wind Cost Trends}

\subsubsection{Levelized Cost of Energy}

Offshore wind is among the renewable energy technologies that has experienced a rapid cost decline in recent years. It is commonly expected that this cost reduction trend will continue globally and will be realized in the United States as the market emerges. Figure 33 provides a survey of LCOE estimates and projections for fixedbottom technologies from a variety of research organizations and consultancies.

\footnotetext{
${ }^{61}$ Note that various technologies can bid under the United Kingdom tender scheme, including (but not limited to) offshore wind. However, in previous auctions, offshore wind was awarded the largest share.
} 


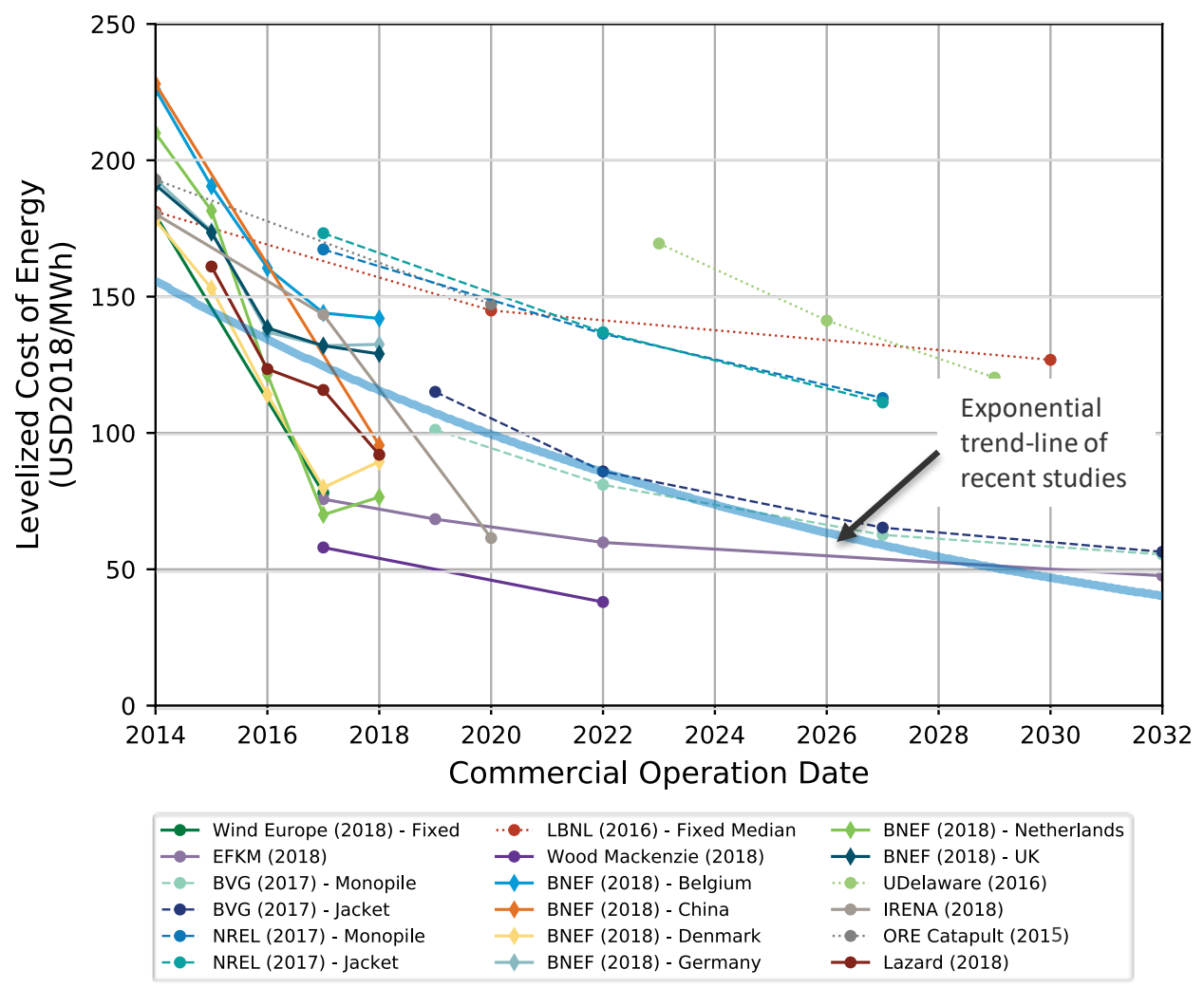

Figure 33. Global LCOE estimates for fixed-bottom offshore wind 62

Sources: WindEurope (2018), Danish Ministry of Energy, Utilities and Climate (2018), Valpy et al. (2017), Beiter et al. (2017), Wiser et al. (2016), Barla (2018), BNEF (2018b, 2018c), Kempton et al. (2016), IRENA (2018), ORE Catapult (2015), and Lazard (2018)

In Figure 33, the 2018 cost projections are shown in solid lines, whereas earlier studies are plotted with dashed lines. The wide blue trend line represents an exponential fit of the most recent data from studies published in 2018, as well as Valpy et al. (2017) projections, which extend to 2032. This trend line suggests a decrease from LCOE levels of about $\$ 120 / \mathrm{MWh}$ in 2018 to $\$ 50 / \mathrm{MWh}$ by 2030 . The trend line is meant to serve as a visual reference to focus on the most recent cost projections.

Projections informed by a learning curve approach offer a complementary method for forecasting future cost reductions (Wiser et al. 2016). Based on industry growth projections, the cumulative capacity of the global industry is likely to experience approximately three doublings, or a total growth of eight times its current capacity, by 2030. IRENA (2018) estimates a learning rate for offshore wind of approximately $14 \%$ per doubling over the period 2010-2020, which would indicate possible LCOE reductions of over 35\% based on industry growth projections of 154-193 GW globally by 2030 (see Section 3.2.3).

\subsubsection{Capital Expenditures}

CapEx are the single largest contributor to the life cycle costs of offshore wind power plants and include all expenditures incurred prior to the COD. Figure 34 shows the reported CapEx over time for operational projects as well as for those in various stages of the near-term project pipeline globally. Each bubble represents the cost estimate (in terms of $\$ / \mathrm{kW}$ ) for a single project and bubble size represents the project's capacity.

\footnotetext{
62 "LBNL" in the figure refers to Berkeley Lab
} 
After a period of increasing project CapEx until 2014 (Musial et al. 2017), an industry trend of declining CapEx has developed, with a capacity-weighted average CapEx of $\$ 4,350 / \mathrm{kW}$ in 2018 globally. WindEurope reported a European project CapEx of $\$ 2,870 / \mathrm{kW}$ in 2019, a 45\% reduction since 2015 (Brindley 2019).

Reported project data suggest a gradual decline of CapEx to levels in the range of $\$ 2,500-\$ 4,000 / \mathrm{kW}$ between 2020 and 2030. The underlying data for Figure 34 include considerable variation of CapEx within a given year. For projects with a COD in 2018, CapEx ranges from approximately $\$ 2,470 / \mathrm{kW}$ (Jiangsu Luneng Dongtai project, China [200 MW]) to $\$ 6,500 / \mathrm{kW}$ (Galloper project, United Kingdom [353 MW]) among projects with capacities greater than $100 \mathrm{MW}$. Several factors may possibly explain the variation in CapEx within a given year and over time (Smith, Stehly, and Musial 2015), including:

- Varying spatial conditions (e.g., water depth, distance to port, point of interconnection, and wave height of sites that affect technical requirements of installing and operating a wind farm)

- Project size

- Different levels of supply chain shortages (e.g., components, vessels, and skilled labor)

- Changing prices for commodities and energy

- Macroeconomic trends, such as fluctuating exchange rates

- A change in the appreciation of the costs and risks associated with offshore wind project implementation, which reflects in pricing strategies from equipment suppliers and installation contractors.

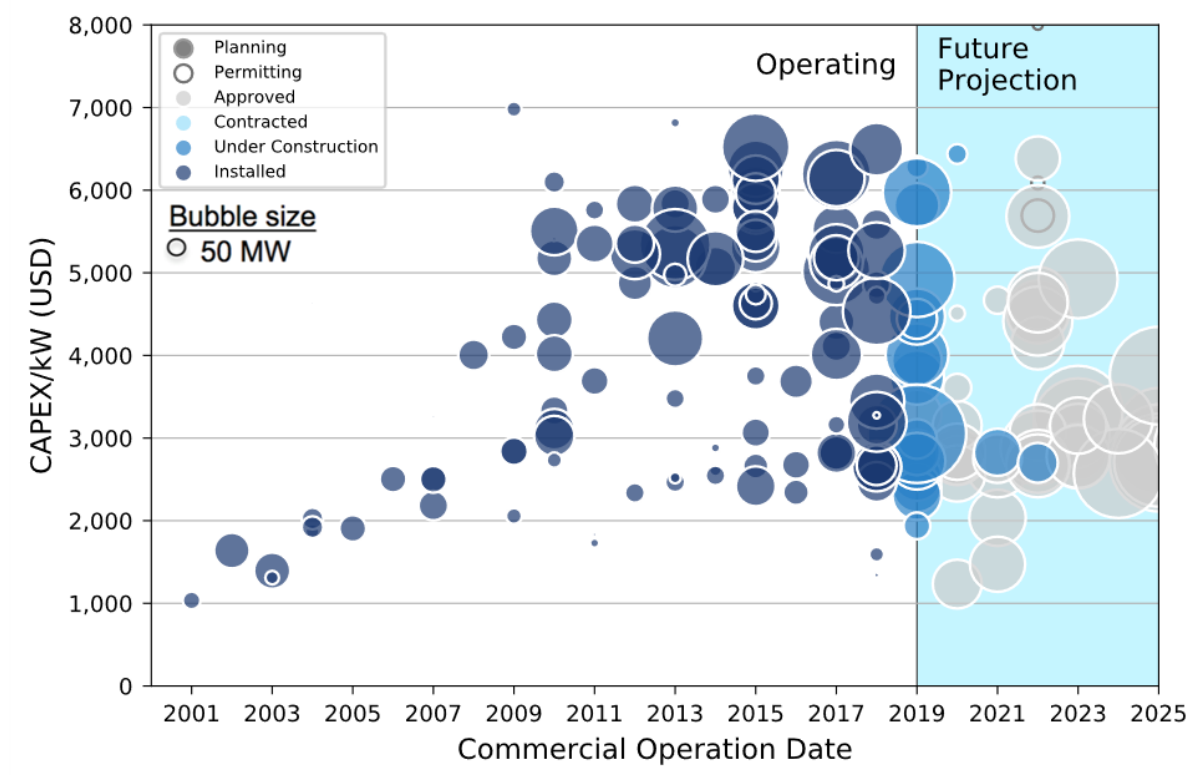

Figure 34. Capital expenditures of global offshore wind projects by commercial operation date and project capacity

Note: Only projects with CapEx greater than $\$ 800 / \mathrm{kW}$ included.

Note that only limited CapEx data are available for any given year before 2010 and after 2025. As a result of this relatively small sample, and the projects' early planning stages in which firm contracts for capital equipment have yet to be executed, the level of confidence is relatively low for some years.

CapEx has been reported for $67,185 \mathrm{MW}$ of global offshore wind projects. Figure 34 shows the announced costs for 123 installed projects $(20,198 \mathrm{MW}), 21$ projects $(7,198 \mathrm{MW})$ that have started construction, 14 projects $(4,848$ MW) that have secured financial close, 56 projects $(34,009 \mathrm{MW})$ that have received regulatory approval, 5 projects $(575 \mathrm{MW})$ in the permitting process, 1 project $(300 \mathrm{MW})$ that is still in the planning phase, and 8 projects 
(58 MW) that are decommissioned. These CapEx data have some uncertainty for various reasons: 1) the CapEx data are normally self-reported by developers and difficult to verify independently, 2) there is limited transparency into the financial impact of cost overruns, and 3) it is often unclear whether the reported CapEx fully captures the total cost of installing the project and connecting it to the grid. ${ }^{63}$ When viewed together, though, these data can provide insight into the long-term cost trends. Generally, greater confidence can be placed in cost estimates that are in more mature stages of the project life cycle (i.e., costs for projects that have reached the financial investment decision are typically more accurate than for a project that has not yet received permits); however, preliminary estimates provide insight into developer expectations about cost trends.

\subsubsection{Wind Turbine Cost}

Offshore turbine costs are estimated to be between $30 \%$ and $45 \%$ of the total CapEx. Typically, turbine price data come from turbine supply agreements that are negotiated for each project, but because of their proprietary nature these data are very limited. Turbine prices may vary considerably among specific projects. Some of the factors in turbine pricing include delivery costs to the staging port, warranty period (typically 5 years), availability guarantees, project order size, turbine attributes (e.g., turbine rating and drivetrain topology), market competition, timing, and specific strategic market behavior (e.g., first-mover advantages, customer retention). Turbine CapEx has declined rapidly over the last few years, which has led to a considerable spread in price estimates found in publicly available literature sources. Figure 35 shows turbine CapEx estimates published between 2016 and 2019, which illustrate considerable variation yet a general trend of price decline in turbine CapEx between 2010 and 2030.

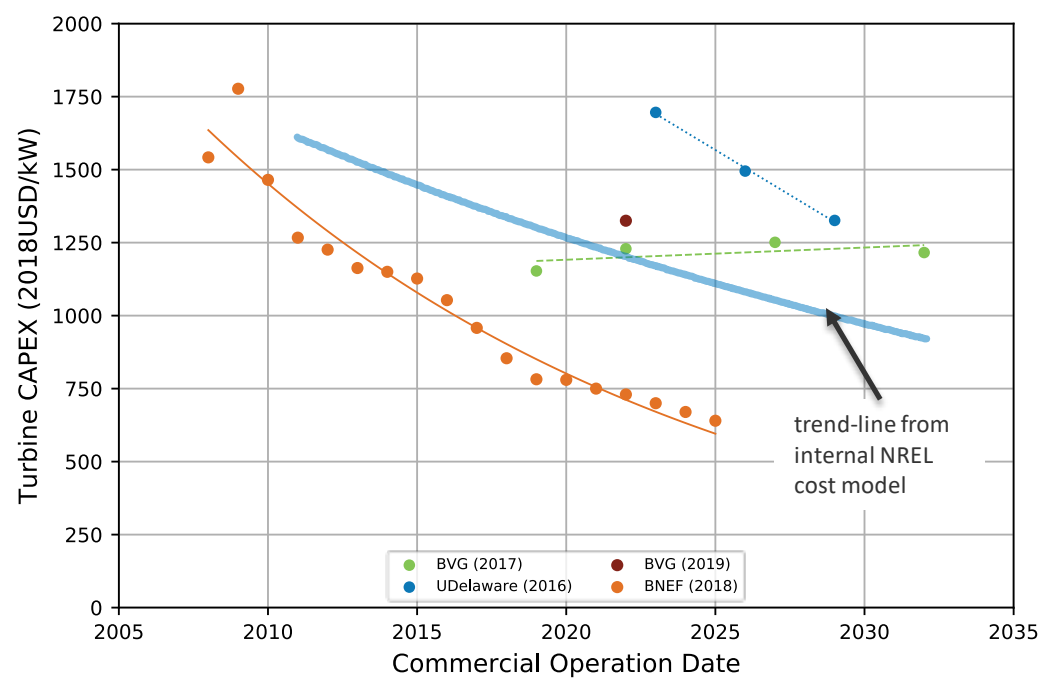

Figure 35. Turbine CapEx trend estimates

Sources: Valpy et al. (2017), ${ }^{64}$ Kempton et al. (2016), BVG Associates (2019), and BNEF (2018e)

Available cost studies indicate that turbine CapEx could range between $\$ 800 / \mathrm{kW}$ and $\$ 1,200 / \mathrm{kW}$ in 2018-2019. BNEF (2018d) numbers were the lowest and estimate a reduction trend reaching $\$ 640 / \mathrm{kW}$ by 2025. Valpy et al. (2017) illustrates the impact from larger turbine ratings of 6 MW (2019), 10 MW (2022), and 12 MW (2027 and 2032) on turbine CapEx. The increase in turbine CapEx from Valpy et al. (2017) is found to be relatively small on a $\$ / \mathrm{kW}$ basis, which would allow for a significant decrease of total system costs

\footnotetext{
${ }^{63}$ For example, it is unclear if the announced capital expenditure values include soft costs, such as construction, financing, insurance, or fees.

${ }^{64}$ Note: In contrast to the other sources, this estimate from Valpy et al. (2017) explicitly includes the impact from an increase in turbine rating (over time) on turbine CapEx (\$/kW) (i.e., from turbine ratings of 8 MW [2018] up to $12 \mathrm{MW}$ ([2027 and 2032]).
} 
on a $\$$ MWh basis. Kempton et al. (2016) estimated considerably higher turbine CapEx from their 2016 study but show a similar cost reduction rate as BNEF (2018d).

The highest commercially available turbine rating is expected to grow from $9.5 \mathrm{MW}$ in $2018^{65}$ to $15 \mathrm{MW}$ or higher over the next decade (see Section 4), which presents one of the primary areas for future cost reduction (e.g., Wiser et al. 2016). Using higher-rated turbines for a given project size reduces the number of turbines to be installed and serviced, effectively decreasing the unit costs for balance-of-station $(\$ / \mathrm{kW})$ and O\&M activities $(\$ / \mathrm{kW} /$ year). In addition, consultation with industry experts and turbine manufacturers suggests that higher turbine rating may not necessarily result in an increase in turbine CapEx $(\$ / \mathrm{kW})$. Turbine manufacturers have reportedly been able to increase turbine rating without increasing the unit cost of the turbine $(\$ / \mathrm{kW})$. Through continued innovations, such as the use of lightweight materials, advanced manufacturing methods, systemwide load control, and economies of scale in production and delivery, turbine manufacturers may be able to offset other cost increases (such as specific mass increases) caused by upscaling. Some evidence of this trend might be found in a review of the GE Haliade-X technical specifications by Pondera Consult, which reports only a slight increase in specific mass for the Haliade-X turbine at 68.8 tonnes per megawatt $(\mathrm{t} / \mathrm{MW})$ including the nacelle, blades, and hub - compared to the MHI Vestas V164-8MW specific mass of $62.5 \mathrm{t} / \mathrm{MW}$. This emerging trend in turbine lower mass/cost growth must be further validated but could provide a further economic motivation for upscaling to larger turbines (de Vries 2019). ${ }^{66}$

\subsubsection{Operational Expenditures}

OpEx cover all costs incurred after COD — but before decommissioning — that are required to operate the project and maintain turbine availability to generate power. These expenditures are generally thought to contribute between $20 \%$ and $30 \%$ to life cycle costs for offshore wind projects, depending on site characteristics. The strongest drivers are distance from the O\&M port, accessibility limits related to local meteorological ocean conditions (e.g., wave height), and turbine rating (i.e., fewer, larger turbines suggest lower O\&M costs per megawatt). To optimize the balance between OpEx and availability, operators adopt different logistical strategies for individual projects depending on site conditions (DNV GL 2013). OpEx for offshore wind projects are subject to considerable uncertainty because of a lack of empirical data. Although wind project owners commonly report CapEx, they rarely report OpEx.

\subsubsection{Financing}

In contrast to fossil-fueled power plants (e.g., natural gas or coal), variable costs of offshore wind plants are relatively small, and most lifetime costs are incurred up-front through CapEx for the development and construction of a project. These up-front expenditures generally require investment volumes of more than $\$ 1$ billion for utility-scale projects $(>200 \mathrm{MW}) .{ }^{67}$ The financing rate of a project, commonly expressed in terms of the weighted-average cost of capital, ${ }^{68}$ has considerable impact on lifetime project costs (i.e., LCOE) because it determines the annual debt service and equity repayment for the initial (CapEx) investment.

During 2018, offshore wind projects in Europe and Asia continued to access low-cost capital, consistent with a broader trend of declining equity and debt rates for renewable energy asset financing in recent years. Nearly $\$ 12$ billion was invested in new European offshore wind capacity (4.2 GW) during 2018, which comprised $24 \%$ of the total investment in new power generation assets in Europe. ${ }^{69}$ Although the total investment volume is lower compared to the levels between 2015 and 2016, installed capacity levels were considerably higher "as a result of cost reductions and sector maturity, particularly for offshore wind" (Brindley 2019). In Europe, project finance dominated offshore wind investment transactions during 2018 with a share of $77 \%$. This drastically reverses the trend of widespread balance-sheet financing from previous years and reflects growing

\footnotetext{
${ }^{65}$ MHI Vestas V164-9.5 MW turbine.

${ }^{66}$ Note that the described trend between turbine rating and turbine CapEx may only apply to a certain range of turbine ratings.

${ }^{67}$ For instance, the 800-MW Vineyard Wind project has a reported investment volume of approximately $\$ 2$ billion (Renewables Now 2018).

${ }^{68}$ Weighted-average cost of capital is the average cost of all sources of capital based on the percentage contribution to the total capital structure.

${ }^{69}$ Major offshore wind projects that reached their financial investment decision were Moray East and Triton Knoll (both in the United Kingdom) and Borssele III and IV (the Netherlands).
} 
comfort with the risks associated with constructing and operating an offshore wind plant, as well as the entry of smaller developers who can take advantage of a favorable lending market (Brindley 2019). Table 15 depicts financing conditions typical for European offshore wind projects between 2006 and 2018 (Guillet 2018). The share of debt in European project financing has been consistently at or above $70 \%$ since 2012, including in 2018. Brindley (2019) reports debt share of up to $90 \%$ for European offshore wind financing in 2018, exceeding those of land-based wind farms. These financing terms are generally expected to carry into 2019 (Brindley 2019).

Table 14. Typical Financing Conditions for European Offshore Wind Projects

\begin{tabular}{|l|l|l|}
\hline Year & Debt-to-Equity Ratio & Pricing ${ }^{70}$ (Basis Points) \\
\hline $\mathbf{2 0 0 6 - 2 0 0 7}$ & $60: 40$ & $150-200$ \\
\hline $\mathbf{2 0 0 9 - 2 0 1 1}$ & $65: 35$ & $300-350$ \\
\hline $\mathbf{2 0 1 2 - 2 0 1 3}$ & $70: 30$ & $200-250$ \\
\hline $\mathbf{2 0 1 4 - 2 0 1 5}$ & $70: 30$ & $200-250$ \\
\hline $\mathbf{2 0 1 6 - 2 0 1 7}$ & $75: 25$ & $150-225$ \\
\hline $\mathbf{2 0 1 8}$ & $70: 30$ & $120-175$ \\
\hline
\end{tabular}

Source: Reprinted from Guillet (2018)

Note: Year 2008 not available from source.

Debt

Debt rates for global offshore wind financing remain at historically low levels, ranging between 3\% and 4\% for 15-year debt terms (Guillet 2018). Debt maturity (post completion) ranged between 10 and 18 years, depending (among other factors) on the length and structure of the offtake conditions. These debt terms correspond to land-based wind financing in the United States (Wiser and Bolinger 2018). Consultation with industry experts suggests that debt financing rates for commercial-scale offshore wind projects will be similar to commercial-scale projects in the United States.

Equity

Driven by high demand for relatively predictable long-term cash flow and technology characteristics that are increasingly well-understood, equity rates for offshore wind have decreased in recent years. A greater variety of equity investor classes seems to be comfortable with the risk profiles of offshore wind, such as pension and insurance funds. Further, equity refinancing of operational projects has become more prevalent in established offshore wind markets. During 2018, the debt refinancing volume was nearly $\$ 10$ billion for four European offshore wind farms completing their construction phase (Brindley 2019).

Emerging information for the U.S. market suggests that European financing terms are generally applicable to a U.S. project finance context. In the United States, it is generally expected that several different types of entities will participate in the financing of commercial-scale offshore wind projects, including commercial banks, export credit agencies, and institutional investors (e.g., pension funds, insurance funds, and infrastructure investors). The engagement of Copenhagen Infrastructure Partners in the Vineyard Wind project may indicate that major international infrastructure investors recognize the potential of the U.S. offshore wind market. A similar motivation might apply to the market entry of major oil and gas corporations as well as supply chain companies (i.e., manufacturers and marine contractors) acting as offshore wind investors globally and in the United States.

\footnotetext{
${ }^{70}$ Basis points are indicated above the London Interbank Offer Rate. One basis point is equal to $1 / 100$ of a percent and 100 basis points equals $1 \%$.
} 
Important U.S.-specific financing considerations include, but are not limited to:

- Tax Credits. Offshore wind projects in the United States may currently elect the ITC or production tax credit. It is commonly expected that U.S. offshore wind projects will have a preference to elect the ITC; however, choosing between election of the ITC versus the PTC depends on a number of financial and legal considerations influenced by the anticipated energy production and operational risks. Pursuant to the Consolidated Appropriations Act, 2016 (P.L. 114-113), these tax credits are on a phase-down schedule (Table 15), thereby limiting the number of offshore wind projects that are expected to benefit from these tax provisions. Some large-scale projects have reportedly grandfathered their election of the ITC/production tax credit by commencing "physical work of a significant nature" on the facility or by incurring at least $5 \%$ of the total cost of the facility under the ITC phase-down rate schedule (Deloitte 2017). During 2018, some concerns were raised whether large-scale projects, such as the 800-MW Vineyard Wind project, would be able to raise unprecedented volumes of tax equity financing for a single project of up to $\$ 600$ million (Deepwater Wind 2018). Financial close of the Vineyard Wind project is expected during 2019 and will allow for a better understanding of whether enough tax equity is available at these investment levels. Election of these tax credit provisions influences the optimal financing structure of an offshore wind project with a higher share of equity and back-leveraged (i.e., the loan is collateralized by the sponsor's equity in the project), so that the benefits from the tax incentive can be fully utilized. As a result of the tax credit phase out, optimal offshore wind financing structures are expected to be impacted (i.e., lower equity share).

Table 15. ITC Phase-Down Rate Schedule

\begin{tabular}{|l|l|}
\hline Construction Start Before & Applicable ITC Rate \\
\hline $\mathbf{1 / 1 / 2 0 1 7}$ & $30 \%$ \\
\hline $\mathbf{1 / 1} 2018$ & $24 \%$ \\
\hline $\mathbf{1 / 1 / 2 0 1 9}$ & $18 \%$ \\
\hline $\mathbf{1 / 1 / 2 0 2 0}$ & $12 \%$ \\
\hline On or after $\mathbf{1 / 1 / 2 0 2 0}$ & $0 \%$ \\
\hline
\end{tabular}

Source: Reprinted from Deloitte (2017)

- Installation and operation contingencies. Consultation with industry experts suggests that early commercial-scale U.S. projects might expect higher contingency levels relative to the established European offshore wind markets. These serve to account for less experience in U.S. offshore wind power plant installation and operation with the risk of incurring delays and interruptions in the supply chain, marine logistics, and permitting processes.

- Offtake mechanisms. Current U.S. offtake mechanisms (Section 2.4.1) are generally seen as attractive to global offshore wind developers because of their relatively low merchant price exposure. Higher uncertainty in revenue streams and declining margins in established offshore wind markets in Europe and Asia might have been primary factors in yielding the high bid prices for lease areas auctioned during 2018. 
- Permitting. In the United States, a federal, state, and local permit to construct and operate a wind power plant is not included in a lease award. This might introduce additional risk from legal action, permitting delays, and stranded assets compared to acquiring a fully permitted lease area. ${ }^{71}$

The Vineyard Wind PPA pricing suggests that there is only a small premium for "new market" risk (Beiter et al. 2019). Consultation with industry experts suggests that investors are available for the different types of risk profiles of each project phase (e.g., developers, private equity, independent power producers, utilities, tax equity, green banks, export credit agencies, manufacturers). A variety of financial vehicles could be utilized to mitigate the risk exposure of early projects, including tax incentives, bonus appreciation, loan guarantees, and financial hedging products. Coincident with the phase out of tax credits over the next few years, high RPS requirement levels are starting to take effect in coastal states, which might mitigate some of the lost tax benefits.

\subsection{Floating Cost Trends}

Although still in the precommercial phase of maturity, floating wind technology has gained greater mainstream recognition over the past year, partially because of Equinor's successful deployment and operation of the Hywind II pilot project near Peterhead, Scotland. Today, floating wind is generally considered a viable technology for the future of offshore wind. Figure 36 depicts LCOE trends estimated by various research organizations and consultancies that show a reduction from levels from above \$175/MWh (2018) to \$70/MWh (2030).

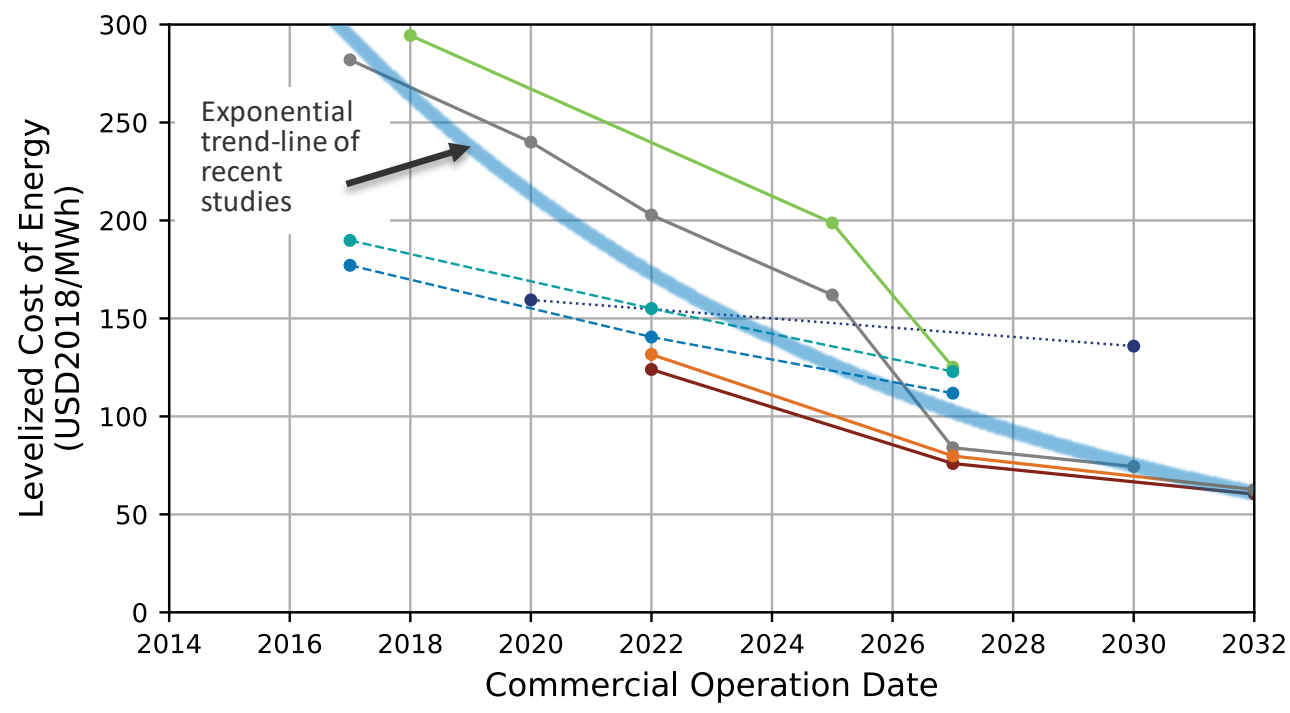

$\begin{array}{llll}\rightarrow-\text { Wind Europe (2018) - Floating } & -\bullet \text { NREL (2017) - Semi } & \cdots \cdots & \text { LBNL (2016) - Floating Median } \\ \rightarrow-\text { BVG (2017) - Semi } & -\bullet \text { NREL (2017) - Spar } & \rightarrow-\text { ORE Catapult (2018) } \\ \multimap & & \end{array}$

Figure 36. Global LCOE estimates for floating technology 72

Sources: WindEurope (2018), Hundleby et al. (2017), Beiter et al. (2017), Wiser et al. (2016), ORE Catapult $(2018)^{73}$

\footnotetext{
${ }^{71}$ For instance, in past German offshore wind auctions, prepermitted lease areas were awarded.

72 "LBNL" in the figure refers to Berkeley Lab

${ }^{73}$ Estimates from ORE Catapult (2018) were converted from $£ 2012$ to $\$ 2018$ using 2012 exchange rates and applying a cumulative U.S. inflation factor of 9.4\% for the period 2012-2018. The ORE Catapult (2018) estimates reflect demonstration (2018), precommercial (2025), and commercial status (2027).
} 
Note that the number of sources for floating wind cost is smaller than for the fixed-bottom trends. These estimates, except for those provided by ORE Catapult (2018) prior to 2027, assume commercial-scale floating wind plants and learning curve benefits commensurate with a mature industry. The blue trend line represents an exponential fit of the most recent studies from 2018. This trend line is meant to serve as a visual reference to focus attention on the most recent cost projections. Cost estimates assuming a commercial-scale floating project size, published prior to 2018, predict higher costs than those published more recently. This might reflect more accurate cost data and new data on anticipated fixed-bottom cost reductions that are applicable to floating systems, as well as increased optimism that technical challenges can be overcome.

The anticipated cost reductions between 2015 and 2030 are related to an expected floating deployment trajectory that spans from existing single-turbine demonstration projects (2015-2017) to multiple-turbine demonstration projects (2017-2022), and finally, to medium- to full-scale commercial projects (early to late 2020s). Globally, there is currently a wide range of floating technology concepts under consideration that are at the multiturbine demonstration phase.

The cost of floating wind technology is currently based on a small set of data from the first phase of prototypes and projects in the design or construction phase. Generally, the potential for cost reduction is high because early-stage technology advances usually result in significant cost reductions. In addition, technological and commercial developments from fixed-bottom wind systems might translate to floating wind systems. Cost estimates from NREL's geospatial analysis (Beiter et al. 2016; Gilman et al. 2016) indicate that floating costs may show a steeper rate of cost reduction than fixed-bottom systems, with the potential for cost parity over the next 10 years. The basis for technology-specific cost reduction potential comes from a range of factors, including (but not limited to) the ability of floating systems to:

- Leverage cost reductions, innovations, and experience from fixed-bottom systems

- Utilize existing supply chains

- Optimize using lighter components and increased modularity

- Reduce the number and complexity of construction steps at sea (e.g., by assembling the turbine and substructure at quayside)

- Automate production and fabrication of the floating platforms

- Access higher wind speeds sufficient to outweigh the higher O\&M and installation costs associated with greater distances to shore and harsher meteorological conditions.

For a more detailed discussion of possible methods to reduce the cost of floating systems, see Beiter et al. (2016). 


\section{Primary Database Sources}

- 4C Offshore. 2018. Offshore Wind Farms Intelligence.

http://www.4coffshore.com/windfarms/request.aspx?id=owfdb.

- $\quad$ 4C Offshore. 2019. Global Offshore Wind Farms Intelligence.

http://www.4coffshore.com/windfarms/request.aspx?id=owfdb.

- Bloomberg New Energy Finance. 2018. Renewable Energy Project Database.

https://about.bnef.com/.

- MAKE Consulting. 2018. Global Offshore Wind Power Project Database.

http://www.consultmake.com/research/databases.

- WindEurope. 2019. Offshore Wind in Europe: Key trends and statistics 2018. February 2019. https://windeurope.org/about-wind/statistics/offshore/european-offshore-wind-industry-key-trendsstatistics-2018/.

\section{References}

The 100 Percent Clean Energy Act of 2018. Senate Bill No. 100.

https://leginfo.legislature.ca.gov/faces/billTextClient.xhtml?bill_id=201720180SB100.

4C Offshore. 2017. "Siemen's 8-megawatt wind turbine up and running." January 30, 2017.

https://www.4coffshore.com/news/siemens-8-megawatt-wind-turbine-up-and-running-nid5241.html.

4C Offshore. 2018. Offshore Wind Farms Intelligence.

http://www.4coffshore.com/windfarms/request.aspx?id=owfdb.

4C Offshore. 2019a. “Ørsted suspends Taiwan developments.” January 21, 2019.

https://www.4coffshore.com/news/\%C3\%B8rsted-suspends-taiwan-developments-nid11111.html.

4C Offshore. 2019b. "Kincardine Offshore Windfarm Project Offshore Wind Farm."

https://www.4coffshore.com/windfarms/kincardine-offshore-windfarm-project-united-kingdom-uk $2 \mathrm{~h} . \mathrm{html}$.

Adwen GmbH. 2019. “Adwen (company).” Accessed April 26, 2019.

https://en.wikipedia.org/wiki/Adwen_(company).

Barla, Sashi. 2018. “Global Wind Turbine Technology Trends.” Market Report. Wood Mackenzie.

Bay State Wind. 2018. "Bay State Wind plans more than $\$ 2$ million in environmental research grants." Press Release. April 10, 2018. https://baystatewind.com/News/2018/04/Bay-State-Wind-plans-more-than-2-millionin-environmental-research-grants.

Beiter P., W. Musial, A. Smith, L. Kilcher, R. Damiani, M. Maness, S. Sirnivas, T. Stehly, V. Gevorgian, M. Mooney, G. Scott. 2016. A Spatial-Economic Cost Reduction Pathway Analysis for U.S. Offshore Wind Energy Development from 2015-2030 (Technical Report). NREL/TP-6A20-66579. National Renewable Energy Laboratory (NREL), Golden, CO (US). www.nrel.gov/docs/fy16/66579.pdf. 
Beiter P., W. Musial, A. Smith, L. Kilcher, R. Damiani, M. Maness, S. Sirnivas, T. Stehly, V. Gevorgian, M. Mooney, G. Scott. 2016. A Spatial-Economic Cost Reduction Pathway Analysis for U.S. Offshore Wind Energy Development from 2015-2030 (Technical Report). NREL/TP-6A20-66579. National Renewable Energy Laboratory (NREL), Golden, CO (US). www.nrel.gov/docs/fy16/66579.pdf.

Beiter, Philipp, Walter Musial, Levi Kilcher, Michael Maness, and Aaron Smith. 2017. An Assessment of the Economic Potential of Offshore Wind in the United States from 2015 to 2030 (Technical Report). NREL/TP6A20-67675. Golden, CO: National Renewable Energy Laboratory.

https://www.nrel.gov/docs/fy17osti/67675.pdf.

Beiter, Philipp, Paul Spitsen, Jake Nunemaker, Tian, Walter Musial, Eric Lantz, and Vahan Gevorgian. 2018. 2017 Offshore Wind Technologies Market Update. Washington, D.C.: U.S. Department of Energy Office of Energy Efficiency \& Renewable Energy. https://www.energy.gov/eere/wind/downloads/2017-offshore-windtechnologies-market-update.

Beiter, Philipp, Paul Spitsen, Walter Musial, and Eric Lantz. 2019. The Vineyard Wind Power Purchase Agreement: Insights for Estimating Costs of U.S. Offshore Wind Projects (Technical Report). National Renewable Energy Laboratory (NREL), Golden, CO. NREL/TP-5000-72981. https://www.nrel.gov/docs/fy19osti/72981.pdf.

Benson, J. 2018. "Future Grid - Sun, Wind and BESS.” Accessed April 22, 2019. https://www.energycentral.com/c/cp/future-grid-sun-wind-and-bess.

Bloomberg New Energy Finance (BNEF). 2018a. 2H 2018 Offshore Wind Market Outlook. https://about.bnef.com/.

BNEF. 2018b. "Current LCOE by Technology." https://www.bnef.com/core/lcoe?tab=Current\%20LCOE\%20by\%20Technology.

BNEF 2018c. "Historic LCOEs: 2H 2018.” https://www.bnef.com/core/lcoe?tab=Historic\%20LCOE.

BNEF. 2018d. "First Big U.S. Offshore Wind Farm Offers \$1.4 Billion to Customers." Accessed November 2018. https://www.bloomberg.com/news/articles/2018-08-01/first-big-u-s-offshore-wind-offers-1-4-billion-tocustomers.

BNEF. 2018e. "2H 2018 Wind Turbine Price Index.” Accessed February 1, 2019. https://www.bnef.com/core/. (BOEM) Bureau of Ocean Energy Management. 2018. "Renewable Energy Path Forward on the Atlantic." Request for Information. https://www.boem.gov/Renewable-Energy-Path-Forward.

BOEM. 2019a. "Massachusetts Leases OCS-A 0500 (Bay State Wind) and OCS-A 0501 (Vineyard Wind)." Accessed April 2019. https://www.boem.gov/commercial-wind-leasing-offshore-massachusetts/.

BOEM. 2019b. "New York Bight.” Accessed June 2019. https://www.boem.gov/NY-Bight/.

BOEM. 2019c. "California Activities.” Accessed June 2019. https://www.boem.gov/California/.

BOEM. 2019d. "Hawaii Activities" Accessed June 2019. https://www.boem.gov/Hawaii/.

BOEM 2019e. BOEM Environmental Studies. Accessed June 2019. https://www.boem.gov/RenewableEnergy-Environmental-Studies/.

Business Network for Offshore Wind. 2019. "Leadership 100 Work Plan.” June 3, 2019. https://www.offshorewindus.org/wp-content/uploads/2019/06/L100WhitePaperJun.3.2019.pdf. 
Brindley, Guy. 2019. Financing and investment trends. The European Wind Industry in 2018. WindEurope. https://windeurope.org/wp-content/uploads/files/about-wind/reports/Financing-and-Investment-Trends2018.pdf.

BVG Associates. 2018a. Offshore wind in Virginia: A vision. September 2018. https://files.vasierraclub.org/oswvision.pdf.

BVG Associates. 2018b. The Virginia advantage: The roadmap for the offshore wind supply chain in Virginia.

https://static1.squarespace.com/static/5b3cf461d274cb109aa488d8/t/5c23e225562fa 7be221 fe841/1545855531 929/BVGA-20802-Report-r2-final-20181227.pdf.

BVG Associates. 2019. "Guide to an Offshore Wind Farm." Published on behalf of The Crown Estate and the Offshore Renewable Energy Catapult. https://www.thecrownestate.co.uk/media/2860/guide-to-offshore-windfarm-2019.pdf.

Carbon Trust. 2019. "Carbon Trust's Floating Wind Joint Industry Project reveals winners of dynamic export cable competition." April 17, 2019. https://www.carbontrust.com/news/2019/04/winners-dynamic-exportcable-competition.

Commonwealth of Massachusetts. 2018. An Act to Advance Clean Energy (Bill H. 4857). 190th General Court of Massachusetts. August 9, 2018. https://malegislature.gov/Bills/190/H4857.

Composites World 2014. "Vestas 8-MW turbine begins operation.” February 3, 2014. https://www.compositesworld.com/news/vestas-8-mw-turbine-begins-operation.

Connecticut General Assembly. 2019. House Bill 7156. June 6, 2019.

https://www.cga.ct.gov/asp/cgabillstatus/cgabillstatus.asp?selBillType=Bill\&which year=2019\&bill num=71 $\underline{56}$.

The Crown Estate. 2018. "The Crown Estate shares further detail on plans for Round 4, including proposed locations to be offered for new seabed rights." Press Release. November 16, 2018.

https://www.thecrownestate.co.uk/en-gb/media-and-insights/news/2018-the-crown-estate-shares-further-detailon-plans-for-round-4-including-proposed-locations-to-be-offered-for-new-seabed-rights/.

Davidson and Weston. 2018. "Principle Power joins Senvion's 10MW project." Windpower Offshore. May 4, 2018. Accessed May 2018. https://www.windpoweroffshore.com/article/1463807/principle-power-joinssenvions-10mw-project.

Danish Ministry of Energy, Utilities and Climate. 2018. "Note on technology costs for offshore wind farms and the background for updating CAPEX and OPEX in the technology catalogue datasheets." https://ens.dk/sites/ens.dk/files/Analyser/havvindsnotat translation_eng final.pdf.

Deepwater Wind. 2018. "Case 18-E-0071 - In the Matter of Offshore Wind Energy. Comments of Deepwater Wind, LLC." http://documents.dps.ny.gov/public/Common/ViewDoc.aspx?DocRefId=\%7BE296F037-4F084529-8892-7295F236F80E\%7D.

Deloitte. 2017. “2017 Deloitte Renewable Energy Seminar.” https://www2.deloitte.com/us/en/pages/energyand-resources/events/deloitte-energy-and-resources-conferences-and-training-seminars.html.

Denholm, Paul, Yinong Sun, and Trieu Mai. 2019. An Introduction to Grid Services: Concepts, Technical Requirements and Provision from Wind (Technical Report). National Renewable Energy Laboratory (NREL), Golden, CO. NREL/TP-6A20-72578. https://www.nrel.gov/docs/fy19osti/72578.pdf. 
de Vries, E. 2012. “Close up - Alstom Haliade 6MW prototype.” Windpower Monthly. July 11, 2012. https://www.windpowermonthly.com/article/1140792/close---alstom-haliade-6mw-prototype.

de Vries, E. 2019. "Haliade-X Uncovered: GE Aims for 14MW.” WindPower Offshore, March 4, 2019. https://www.windpoweroffshore.com/article/1577816/haliade-x-uncovered-ge-aims-14mw.

Deign, J. 2019. "China Set to Overtake UK as Offshore Wind Leader by 2021.” Greentech Media. January 31, 2019. https://www.greentechmedia.com/articles/read/uk-set-to-lose-offshore-wind-crown-to-china-by2021\#gs.4ef3uj.

DNV GL. 2013. "A Guide to UK Offshore Wind Operations and Maintenance.” London, UK: Scottish Enterprise and The Crown Estate. http://www.hi-energy.org.uk/Downloads/General\%20Documents/guide-touk-offshore-wind-operations-and-maintenance.pdf.

DOE (U.S. Department of Energy). 2018. Tethys Database. https://tethys.pnnl.gov/.

DOE. 2019. "Offshore Wind Advanced Technology Demonstration Projects.” Accessed April 29, 2019. https://www.energy.gov/eere/wind/offshore-wind-advanced-technology-demonstration-projects.

Durakovic, A. "North Carolina Governor Proposes Offshore Wind Study." OffshoreWIND.biz. March 12, 2019. https://www.offshorewind.biz/2019/03/12/north-carolina-governor-proposes-offshore-wind-study/.

Dvorak, P. 2017. "Inching toward 10 MHI Vestas unwraps a 9.5-MW design." Windpower Engineering. August 2017. https://www.windpowerengineering.com/design/inching-toward-10-mhi-vestas-unwraps-9-5mw-design.

Energy Information Administration. 2019. "Maryland State Profile and Energy Estimates.” Accessed April 2018. https://www.eia.gov/state/?sid=MD.

Equinor. 2018a. "World class performance by world's first floating wind farm." February 15, 2018. Accessed May 2018. https://www.statoil.com/en/news/15feb2018-world-class-performance.html.

Equinor. 2018b. "Equinor has installed Batwind - the world's first battery for offshore wind." June 27, 2018. https://www.equinor.com/en/news/26june2018-equinor-has-installed-batwind.html.

Espérandieu, M. 2018. "État des lieux des projets éoliens au large des côtes françaises.” Mer et Marine. December 6, 2018. https://www.meretmarine.com/fr/content/etat-des-lieux-des-projets-eoliens-au-large-descotes-francaises.

European Commission. 2019. "State aid: Commission approves support for four floating demonstration offshore wind farms in France.” European Commission Press Release. February 25, 2019.

http://europa.eu/rapid/press-release_IP-19-1412_en.htm.

Eversource Energy. 2019. "Ørsted and Eversource Enter 50-50 Partnership Agreement on Key Offshore Wind Assets in the Northeast." Boston, February 8, 2019. Accessed July 2019.

https://www.eversource.com/content/docs/default-source/investors/orsted-partnershipagreement.pdf?sfvrsn=736bcb62 0 .

Fingersh, L., M. Hand, A. Laxson. 2006. "Wind Turbine Design Cost and Scaling Model” National Renewable Energy Laboratory (NREL), NREL/TP-500-40566. https://www.nrel.gov/docs/fy07osti/40566.pdf.

Foxwell, David. 2018a. "Germany back-tracks on commitment to offshore wind auction." Offshore Wind Journal. November 1, 2018. https://www.owjonline.com/news/view,germanybacktracks-on-commitment-tooffshore-wind-auction 55731.htm. 
Foxwell, D. 2018b. "20-GW reference gives German offshore wind industry greater cheer." Offshore Wind Journal. December 4, 2018. https://www.owjonline.com/news/view,20gw-reference-gives-german-offshorewind-industry-greater-cheer_56109.htm.

Foxwell, D. 2018c. "Senvion super-turbine could one day be capable of 16MW." Offshore Wind Journal. July 23, 2018. https://www.rivieramm.com/news-content-hub/senvion-super-turbine-could-one-day-be-capable-of16-mw-23945.

Foxwell, D. 2019. "Ørsted awards crew transfer vessel contract for US market." Offshore Wind Journal. May 9, 2019. https://www.owjonline.com/news/view,rsted-awards-crew-transfer-vessel-contract-for-usmarket 57772.htm.

Froese, M. 2018. "MHI Vestas to supply turbines for WindFloat Atlantic Floating Offshore Wind." Windpower Engineering \& Development. September 10, 2018.

https://www.windpowerengineering.com/business-news-projects/mhi-vestas-to-supply-turbines-for-windfloatatlantic-floating-offshore-wind/.

Froese, M. 2019a. "Responsible Offshore Science Alliance launches to advance research on fisheries and offshore wind." Windpower Engineering \& Development. April 9, 2019.

https://www.windpowerengineering.com/business-news-projects/responsible-offshore-science-alliancelaunches-to-advance-research-on-fisheries-offshore-wind/.

Froese, M. 2019b. "Equinor promotes collaboration between offshore wind and fishing industries." Windpower Engineering \& Development. February 27, 2019. https://www.windpowerengineering.com/business-newsprojects/equinor-promotes-collaboration-between-offshore-wind-and-fishing-industries/.

GE (General Electric). 2018a. "GE announces Haliade-X, the world's most powerful offshore wind turbine." March 1, 2018. Accessed May 2018. https://www.genewsroom.com/press-releases/ge-announces-haliade-Xworlds-most-powerful-offshore-wind-turbine-284260.

GE. 2018b. "Haliade-X Offshore Wind Turbine Platform.” Accessed May 2018.

https://www.ge.com/renewableenergy/wind-energy/turbines/haliade-X-offshore-turbine.

German Offshore Wind Energy Foundation. 2019. "Expansion of Offshore Wind Energy Successfully Continued in 2018 - Industry Sector Calls for Rapid Increase of Expansion Targets.” https://www.offshorestiftung.de/en/expansion-offshore-wind-energy-successfully-continued-2018-industry-sector-calls-rapidincrease.

Gilman, P., B. Maurer, L. Feinberg, A. Duerr, L. Peterson, W. Musial, P. Beiter, J. Golladay, J. Stromberg, I. Johnson, D. Boren, A. Moore. 2016. National Offshore Wind Strategy; Facilitating the Development of the Offshore Wind Industry in the United States. DOE/GO-102016-4866. Washington, D.C.: U.S. Department of Energy Office of Energy Efficiency \& Renewable Energy; U.S. Department of the Interior. https://energy.gov/sites/prod/files/2016/09/f33/National-Offshore-Wind-Strategy-report-09082016.pdf.

Graré, V., F. Kühn, F. Küster, A. Schlosser. 2018. “The offshore-wind industry’s moment of reckoning.” McKinsey \& Company. https://www.mckinsey.com/business-functions/sustainability/our-insights/theoffshore-wind-industrys-moment-of-reckoning?reload.

Guillet, Jerome. 2018. "Who will fund U.S. Offshore Wind-and on what terms?" Presented at the Offshore Wind Implementation Summit, Teaneck, New Jersey, September 7. https://green-giraffe.eu/presentations/whowill-fund-us-offshore-wind- $\% \mathrm{E} 2 \% 80 \% 93$-and-what-terms.

Hill, J. 2018. "How To Typhoon-Proof Offshore Wind Turbines." CleanTechnica. October 7, 2018. https://cleantechnica.com/2018/10/07/how-to-typhoon-proof-offshore-wind-turbines. 
Hill, J. 2019. “Japanese Offshore Wind To Hit 4 Gigawatts In 2028.” CleanTechnica. February 19, 2019. https://cleantechnica.com/2019/02/19/japanese-offshore-wind-to-hit-4-gigawatts-in-2028.

House Bill 226: Maryland Offshore Wind Energy Act of 2013. General Assembly of Maryland. Accessed May 2018. http://mgaleg.maryland.gov/2013RS/bills/hb/hb0226E.pdf.

Hundleby, Giles, Kate Freeman, Andy Logan, and Ciaran Frost. 2017. "Floating Offshore: 55 Technology Innovations That Will Have Greater Impact on Reducing the Cost of Electricity from European Floating Offshore Wind Farms." KiC InnoEnergy and BVG Associates. http://www.innoenergy.com/new-floatingoffshore-wind-report-55-technology-innovations-that-will-impact-the-lcoe-in-floating-offshore-wind-farms/.

International Electrotechnical Commission (IEC) 2019a. IEC 61400-1 Edition 3, Wind turbines-Part 1: Design requirements.

https://www.iec.ch/dyn/www/f?p=103:23:27965083281002:.::FSP_ORG_ID,FSP_LANG_ID:1282,25/.

IEC 2019b. IEC 61400-3 Edition 2, Wind turbines-Part 3: Design requirements for offshore wind turbines. https:/www.iec.ch/dyn/www/f?p=103:23:27965083281002:.::FSP_ORG_ID,FSP_LANG_ID:1282,25/.

International Renewable Energy Agency (IRENA). 2018. Offshore innovation widens renewable energy options: Opportunities, challenges and the vital role of international co-operation to spur the global energy transformation. Brief to G7 policymakers. https://www.irena.org//media/Files/IRENA/Agency/Publication/2018/Sep/IRENA offshore wind brief G7 2018.pdf.

ISO Newswire. 2019. “An Update on Vineyard Wind's Participation in FCA \#13.” February 8, 2019. http://isonewswire.com/updates/2019/2/8/an-update-on-vineyard-winds-participation-in-fca-13.html.

Jacobsen, S. 2018. "Offshore wind power firms see Taiwan as a battleground to expand in Asia." Reuters. Accessed April 2018. https://www.reuters.com/article/us-taiwan-windpower/offshore-wind-power-firms-seetaiwan-as-a-battleground-to-expand-in-asia-idUSKBN1I11IV.

JDR. 2019. "JDR Wins Second Offshore Wind Contract For Major Project In Taiwan." http://www.jdrcables.com/jdr-wins-second-offshore-wind-contract-for-major-project-in-taiwan/.

Kempton, W., S. McClellan, and D. Ozkan. 2016. Massachusetts Offshore Wind Future Cost Study. Technical Report. Special Initiative on Offshore Wind. University of Delaware.

https://www.ceoe.udel.edu/File\%20Library/About/SIOW/MA-Offshore-Wind-Future-Cost-Study-rev-4-April16.pdf.

Krueger, A. D., G. R. Parsons, and J. Firestone. 2011. Valuing the Visual Disamenity of Offshore Wind Projects at Varying Distances from the Shore. University of Delaware, Land Economics. 87 (2): 268-283, ISSN 0023-7639; E-ISSN 1543-8325. https://works.bepress.com/george_parsons/7/.

Lazard. 2018. "Levelized Cost of Energy Analysis, Version 12.0."

https://www.lazard.com/media/450784/lazards-levelized-cost-of-energy-version-120-vfinal.pdf.

Lefevre-Marton, N., Saharia, R, Sellschop, R., and Tai, H. 2019. "Scaling the US East Coast offshore wind industry to 20 gigawatts and beyond." April 2019. https://www.mckinsey.com/industries/electric-power-andnatural-gas/our-insights/scaling-the-us-east-coast-offshore-wind-industry-to-20-gigawatts-and-beyond?reload.

Lillian, B. 2019. "Equinor Wind US Joins Effort To Protect Whales in New York Bight." North American Wind Power. April 9, 2019. https://nawindpower.com/equinor-wind-us-joins-effort-to-protect-whales-in-newyork-bight. 
Linklaters LLP. 2019. “Korea Offshore Wind: Looking Ahead.” Lexology. January 7, 2019. https://www.lexology.com/library/detail.aspx?g=32b9bb3f-1e68-4967-9b08-e71160308bdd.

Maness, Michael, Ben Maples, and Aaron Smith. 2017. NREL Offshore Balance-of-System Model (Technical Report). National Renewable Energy Laboratory (NREL), Golden, CO. NREL/TP-6A20-66874. https://www.nrel.gov/docs/fy17osti/66874.pdf.

Market Research Consulting. 2018. Submarine Power Cable - Global Market Outlook (2017-2026). https://www.researchandmarkets.com/reports/4592698/submarine-power-cable-global-market-outlook.

Maryland General Assembly. 2019. Senate Bill 516. May 25, 2019.

http://mgaleg.maryland.gov/2019RS/bills/sb/sb0516e.pdf.

Massachusetts Department of Energy Resources. 2019a. Request for Proposals For Long-Term Contracts for Offshore Wind Energy Projects. May 23, 2019.

https://macleanenergy.files.wordpress.com/2019/05/83c-ii-rfp_finalpackage.pdf.

Massachusetts Department of Energy Resources. 2019b. Offshore Wind Study. May 31, 2019.

https://www.mass.gov/files/documents/2019/05/31/OSW\%20Study\%20-\%20Final.pdf.

Massachusetts Department of Public Utilities. 2018a. "Offshore Wind Generation Unit Power Purchase Agreement Between NSTAR Electric Company d/b/a Eversource Energy and Vineyard Wind LLC (Facility 1)." July 31, 2018. Redacted. Exhibit JU-3-A.

https://eeaonline.eea.state.ma.us/EEA/FileService/FileService.Api/file/FileRoom/9676522.

Massachusetts Department of Public Utilities. 2018b. "Offshore Wind Generation Unit Power Purchase Agreement Between NSTAR Electric Company d/b/a Eversource Energy and Vineyard Wind LLC (Facility 2)." July 31, 2018. Redacted. Exhibit JU-3-B. https://eeaonline.eea.state.ma.us/EEA/FileService/FileService.Api/file/FileRoom/9676523.

Mass Live. 2018. "Vineyard Wind signs \$9 million lease at New Bedford Commerce Pier." October 23, 2018. https://www.masslive.com/news/2018/10/vineyard_wind_signs 9 million.html.

McClellan. 2019. "Supply Chain Contracting Forecast for U.S. Offshore Wind Power," Special Initiative on Offshore Wind White Paper. Accessed July 2019.

https://www.ceoe.udel.edu/File\%20Library/About/SIOW/SIOW-White-Paper---Supply-Chain-ContractingForecast-for-US-Offshore-Wind-Power-FINAL.pdf.

MHI Vestas. 2018. "Vineyard Wind Selects MHI Vestas as Preferred Supplier for First Large-scale Offshore Wind Project in the United States." November 27, 2018. http://www.mhivestasoffshore.com/vineyard-windselects-mhi-vestas-as-preferred-supplier/.

Mills, J. 2019. "An Order Concluding the Maine Wind Advisory Commission and Wind Permit Moratorium." Office of the Governor. February 14, 2019.

https://www.maine.gov/governor/mills/sites/maine.gov.governor.mills/files/inline-files/EO\%20Wind.pdf.

Musial, W., Z. Parker, J. Fields, G. Scott, and C. Draxl. 2013. Assessment of Offshore Wind Energy Leasing Areas for the BOEM Massachusetts Wind Energy Area (Technical Report). National Renewable Energy Laboratory (NREL), Golden, CO. NREL/TP-5000-60942. http://www.nrel.gov/docs/fy14osti/60942.pdf.

Musial, W., D. Heimiller, P. Beiter, G. Scott, and C. Draxl. 2016. 2016 Offshore Wind Energy Resource Assessment for the United States (Technical Report). National Renewable Energy Laboratory (NREL), Golden, CO. NREL/TP-5000-66599. http://www.nrel.gov/docs/fy16osti/66599.pdf. 
Musial, W., P. Beiter, P. Schwabe, T. Tian, T. Stehly, P. Spitsen. 2017. 2016 Offshore Wind Technologies

Market Report (Technical Report). Washington, D.C.: U.S. Department of Energy Office of Energy Efficiency \& Renewable Energy.

https:/www.energy.gov/sites/prod/files/2017/08/f35/2016\%20Offshore\%20Wind\%20Technologies\%20Marke t\%20Report.pdf.

New Jersey Board of Public Utilities. 2018. Docket No. Q018080843. December 18, 2018.

https://www.bpu.state.nj.us/bpu/pdf/boardorders/2018/20181218/12-18-18-8H.pdf.

New Jersey Board of Public Utilities. 2019. 2019 Annual Report on New Jersey Offshore Wind and the Implementation of Executive Order No. 8. NJ BPU. January 31, 2019.

https:/www.bpu.state.nj.us/bpu/pdf/publicnotice/2019\%20ANNUAL\%20EO8\%20REPORT\%2002082019\%2 0FNL $\% 20 \mathrm{~V} 2 . p d f$.

New Jersey State Legislature. 2018. “A3723.” May 23, 2018. Accessed May 2018.

http://www.njleg.state.nj.us/bills/BillView.asp?BillNumber=A3723.

New York State. 2019a. "2019 State of the State Budget Address.” New York State Governor Andrew M. Cuomo. https://www.ny.gov/programs/2019-state-state-budget-address.

New York State. 2019b. Climate Leadership and Community Protection Act. June 18, 2019. https://www.nysenate.gov/legislation/bills/2019/s6599.

New York State Energy Research and Development Authority (NYSERDA). 2019. "National Offshore Wind R\&D Consortium Research Solicitation (PON 4124)."

https://portal.nyserda.ny.gov/CORE Solicitation Detail Page?SolicitationId=a0rt000000beASkAAM.

Nexans. 2018. "Cable supplies for the world's first 66 KV offshore windfarms." September 2018.

https://www.nexans.com/newsroom/news/details/2018/09/Supply-of-cables-for-the-first-66kv-offshorewindfarms.html.

National Oceanic and Atmospheric Administration (NOAA). 2019a. "Northeast Regional Ocean Council Data Portal.” https://www.northeastoceancouncil.org/quick-links/.

NOAA. 2019b. "Mid-Atlantic Ocean Data Portal.” http://portal.midatlanticocean.org/about-us/.

offshoreWIND.biz. 2018a. "Shell, EDF Acquire US Wind's New Jersey Lease Area.” December 20, 2018. https://www.offshorewind.biz/2018/12/20/shell-edf-acquire-us-winds-new-jersey-lease-area/

offshoreWIND.biz. 2018b. "Poland Sets 8GW by 2035 Offshore Wind Goal." November 8, 2018. https://www.offshorewind.biz/2018/11/08/poland-sets-8gw-by-2035-offshore-wind-goal/.

ORE Catapult. 2015. "Cost Reduction Monitoring Framework: Summary Report to the Offshore Wind Programme Board." ORE Catapult and The Crown Estate.

https://ore.catapult.org.uk/app/uploads/2018/02/Cost-Reduction-Monitoring-Framework-2015.-Summaryreport-to-the-OWPB.pdf.

ORE Catapult. 2018. "Macroeconomic Benefits of Floating Offshore Wind in the UK." Glasgow, UK: Crown Estate Scotland. https://www.crownestatescotland.com/maps-and-publications/download/219.

Orrell, A., N. Foster, S. Morris, J. Homer, D. Preziuso, R. Poehlman. 2019. 2018 Distributed Wind Market Report (Technical Report). Washington, D.C.: U.S. Department of Energy Office of Energy Efficiency \& Renewable Energy. https://energy.gov/eere/wind/downloads/2018-distributed-wind-market-report 
Ørsted. 2018. “Ørsted acquires Deepwater Wind and creates leading US offshore wind platform.” Ørsted Press Release. August 10, 2018. https://orsted.com/en/Company-Announcement-List/2018/10/1819975.

Ørsted. 2019. "TEPCO and Ørsted sign MOU to work jointly on offshore wind projects."

Ørsted Press Release. January 18, 2019. https://orsted.com/en/Media/Newsroom/News/2019/01/TEPCO-andOrsted-sign-MoU-to-work-jointly-on-offshore-wind-projects.

Peregrine Energy. 2018. "Independent Evaluator Report: On the Solicitation, Evaluation, and Bid Process Under Section 83C of the Green Communities Act." Accessed September 2018.

https://eeaonline.eea.state.ma.us/EEA/FileService/FileService.Api/file/FileRoom/9685211.

Power Engineering. 2005. "REpower 5 MW turbines to power Borkum West offshore wind park." September 7, 2005. https://www.power-eng.com/articles/2005/09/repower-5-mw-turbines-to-power-borkum-westoffshore-wind-park.html.

Power Technology. 2018. "Formosa 1 Offshore Wind Farm.” https://www.powertechnology.com/projects/formosa-1-offshore-wind-farm/.

Quest Floating Wind Energy. 2019. "What Will Float in South Korea's Newly Announced Project." March 5, 2019. https://questfwe.com/what-will-float-in-south-koreas-newly-announced-project/.

Ragheb, M. 2019. Modern Wind Generators.

http://mragheb.com/NPRE\%20475\%20Wind\%20Power\%20Systems/Modern\%20Wind\%20Generators.pdf.

Recharge News. 2018. "Chinese wind power faces switch to competition from 2019." Recharge News. June 5, 2018. https://www.rechargenews.com/wind/1504927/chinese-wind-power-faces-switch-to-competition-from2019.

Renewables Now. 2018. "Vineyard Wind Faces Rhode Island Permitting Setback." November 22, 2018. https://renewablesnow.com/news/vineyard-wind-faces-rhode-island-permitting-setback-report-634128/.

Reuters. 2018. "France cuts tariffs on controversial offshore wind projects." Reuters. June 20, 2018. https://www.reuters.com/article/us-france-windpower-offshore/france-cuts-tariffs-on-controversial-offshorewind-projects-idUSKBN1JG1N8.

Rhode Island Coastal Resources Management Council. 2019. “Agreements to Establish RI Fishermen's Future Viability Trust." February 21, 2019. http://www.crmc.ri.gov/windenergy/vineyardwind.html.

Richard, C. 2019. "MHI Vestas in line to supply first V174 turbines." Windpower Offshore. February 2019. https://www.windpoweroffshore.com/article/1525372/mhi-vestas-line-supply-first-v174-turbines.

Saltzberg, R, and B. Dowd. 2019. "RODA and Ørsted Strengthen Dialogue." Martha's Vineyard Times. January 18, 2019. https://www.mvtimes.com/2019/01/18/roda-orsted-strengthen-dialogue/.

Siemens. 2013. Fact Sheet: The new SWT-6.0; The next-generation offshore wind turbine. Status: February 2013. https://www.siemens.com/press/pool/de/feature/2013/energy/2013-01-rotorblade/factsheet-6mw-e.pdf.

Siemens. 2019. "Siemens Gamesa launches $10 \mathrm{MW}$ offshore wind turbine; annual energy production (AEP) increase of 30\% vs. predecessor." https://www.siemensgamesa.com/en-int/newsroom/2019/01/new-siemensgamesa-10-mw-offshore-wind-turbine-sg-10-0-193-dd.

Skopljak, N. 2019a. "Vineyard Wind Commits to Whale Protection.” January 24, 2019. https://www.offshorewind.biz/2019/01/24/vineyard-wind-commits-whale-protection/. 
Skopljak N. 2019b. "Vineyard Wind Seeks Whale Protection Tech." May 22, 2019.

https://www.offshorewind.biz/2019/05/22/vineyard-wind-seeks-whale-protection-tech/.

Skopljak, N. 2019c. “Spain's First Offshore Wind Turbine Goes Into Operation” March 18, 2019. https://www.offshorewind.biz/2019/03/18/spains-first-offshore-wind-turbine-goes-operation.

Smith, Stehly, and Musial. 2015. 2014-2015 Offshore Wind Technologies Market Report (Technical Report). National Renewable Energy Laboratory (NREL), Golden, CO. NREL/TP-5000-64283. https://www.nrel.gov/docs/fy15osti/64283.pdf.

Snieckus. 2018. "Senvion offshore turbine will be 12MW+ model." Recharge News. June 19, 2018. https://www.rechargenews.com/wind/1515084/senvion-offshore-turbine-will-be-12mw+-model.

Stehly, T., D. Heimiller, G. Scott. 2017. 2016 Cost of Wind Energy Review (Technical Report). National Renewable Energy Laboratory (NREL). Golden, CO. NREL/TP-6A20-70363. Accessed May 2018. https://www.nrel.gov/docs/fy18osti/70363.pdf.

Stehly, T., P. Beiter, D. Heimiller, G. Scott. 2018. 2017 Cost of Wind Energy Review (Technical Report). National Renewable Energy Laboratory (NREL). Golden, CO. NREL/TP-6A20-72167. https://www.nrel.gov/docs/fy18osti/72167.pdf.

Sununu, C.T. 2019. "BOEM Renewable Energy Task Force for New Hampshire." Office of the Governor. January 2, 2019. https://www.governor.nh.gov/news-media/press-2019/documents/20190107-boemoffshore.pdf.

T\&D World. 2019. "Prysmian to Develop Submarine Cable System for Floating Offshore Wind Farm." March 20, 2019. https://www.tdworld.com/renewables/prysmian-develop-submarine-cable-system-floating-offshorewind-farm.

University of Delaware. 2016. "Massachusetts Offshore Wind Future Cost Study.” March 2016. https://www.ceoe.udel.edu/File\%20Library/About/SIOW/MA-Offshore-Wind-Future-Cost-Study-FINAL-14Mar-16.pdf.

University of Delaware's Special Initiative for Offshore Wind. 2019. Supply Chain Contracting Forecast for U.S. Offshore Wind Power. March 2019. https://www.ceoe.udel.edu/File\%20Library/About/SIOW/SIOWWhite-Paper---Supply-Chain-Contracting-Forecast-for-US-Offshore-Wind-Power-FINAL.pdf.

United States Department of Labor Bureau of Statistics. 2019. "Overview of BLS Statistics on Inflation and Prices." https://www.bls.gov/bls/inflation.htm.

United States Treasury Bureau of Fiscal Service. 2019. "Treasury Reporting Rates of Exchange." https://www.fiscal.treasury.gov/reports-statements/treaury-reporting-rates-exchange/current.html.

Valpy, B. G. Hundleby, K. Freeman, A. Roberts, A. Logan. 2017. Future renewable energy costs: Offshore wind; 57 technology innovations that will have greater impact on reducing the cost of electricity from European offshore wind farms. InnoEnergy and BVG Associates. http://www.innoenergy.com/wpcontent/uploads/2014/09/InnoEnergy-Offshore-Wind-anticipated-innovations-impact-2017_A4.pdf.

Vineyard Wind LLC. 2018a. Vineyard Wind Offshore Wind Energy Project: Draft Environmental Impact Statement (EEA\#15787). https://www.boem.gov/Vineyard-Wind-EIS/.

Vineyard Wind. 2018b. "Plugging into a new industry.” April 1, 2018. Accessed May 2018. https://www.vineyardwind.com/in-the-news/2018/4/1/plugging-into-a-new-industry. 
Vineyard Wind. 2018c. "Project Update: Vineyard Wind Submits Supplemental Draft Environmental Impact Report for Additional Public Comment." September 4, 2018. https://www.vineyardwind.com/news-andupdates/2018/9/4/project-update-vineyard-wind-submits-supplemental-draft-environmental-impact-reportsdeir-for-additional-public-comment.

Vineyard Wind. 2018d. "Project Update: Vineyard Wind Submits Supplemental Draft Environmental Impact Report for Additional Public Comment." September 4, 2018. https://www.vineyardwind.com/news-andupdates/2018/9/4/project-update-vineyard-wind-submits-supplemental-draft-environmental-impact-reportsdeir-for-additional-public-comment.

de Vries, E. 2019. "Haliade-X Uncovered: GE Aims for 14MW.” WindPower Offshore, March 4, 2019. https://www.windpoweroffshore.com/article/1577816/haliade-x-uncovered-ge-aims-14mw.

Walton, R. 2018. "FERC advances transmission line to serve Massachusetts' offshore wind industry." Utility Dive. Accessed May 2018. https://www.utilitydive.com/news/ferc-advances-transmission-line-to-servemassachusetts-offshore-wind-indus/517125/.

Weston, D. 2019. "Steisdal's TetraSpar demo gets go-ahead." Wind Power Offshore. February 13, 2019. https://www.windpoweroffshore.com/article/1525677/stiesdals-tetraspar-demo-gets-go-ahead.

WindEurope. 2018. Floating Offshore Wind Energy; A Policy Blueprint for Europe. https://windeurope.org/wp-content/uploads/files/policy/position-papers/Floating-offshore-wind-energy-apolicy-blueprint-for-Europe.pdf.

WindEurope. 2019. Offshore Wind in Europe: Key trends and statistics 2018. February 2019. https://windeurope.org/about-wind/statistics/offshore/european-offshore-wind-industry-key-trends-statistics$\underline{2018 / .}$.

Windpower Monthly. 2018. "Who will pay for 15MW turbine?” March 2018. https://www.windpowermonthly.com/article/1457880/will-pay-15mw-turbine.

WireTech. 2019. "JDR selected as preferred cable supplier for Windfloat Atlantic project." http://www.wiretechworld.com/jdr-selected-as-preferred-cable-supplier-for-windfloat-atlantic-project/.

Wiser, R. M. Bolinger, G. Barbose, N. Darghouth, B. Hoen, A. Mills, J. Rand, D. Millsteing, K. Porter, K. Fisher, N. Disanti, F. Oteri. 2018 Wind Technologies Market Report. Lawrence Berkeley National Laboratory. https://www.energy.gov/eere/wind/downloads/2018-wind-technologies-market-report

Wiser, R., K. Jenni, J. Seel, E. Baker, M. Hand, E. Lantz, A. Smith. 2016. Forecasting Wind Energy Costs \& Cost Drivers. The Views of the World's Leading Experts. LBNL-1005717. Lawrence Berkeley National Laboratory. http://eta-publications.lbl.gov/sites/default/files/lbnl-1005717.pdf.

Wiser, Ryan, and Mark Bolinger. 2018. “2017 Wind Technologies Market Report.” DOE/EE-1798. U.S. Department of Energy Office of Energy Efficiency and Renewable Energy. https:/emp.lbl.gov/sites/default/files/2017_wind technologies_market_report.pdf. 


\section{Wind Technologies} Market Report

For more information visit, energy.gov/eere/wind

DOE/GO-102019-5192 • August 2019

Front cover photo from Dennis Schroeder, NREL Back cover photo from Walt Musial, NREL

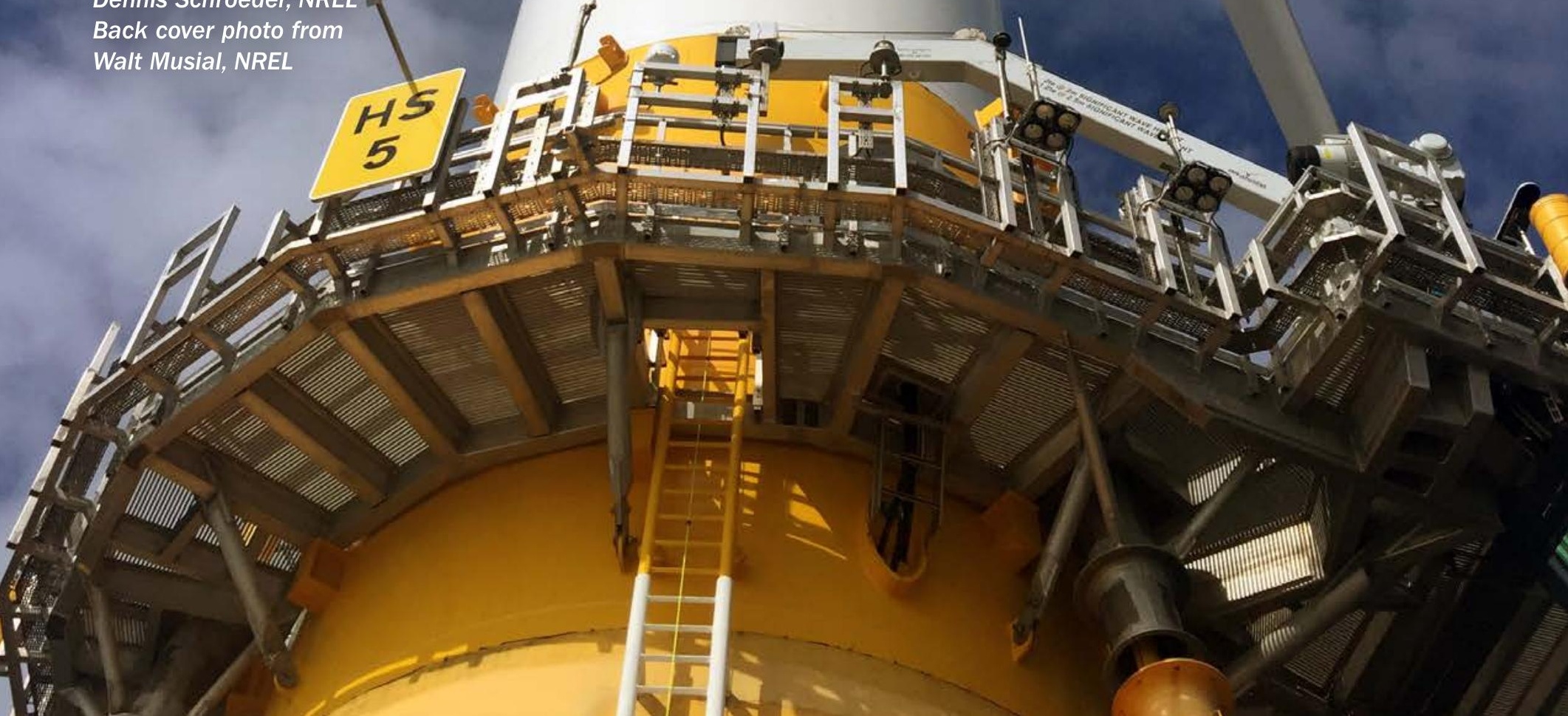

